\title{
Southeast Montana Wetland Assessment: Developing and Refining Montana's Wetland Assessment and Monitoring Strategy
}

\author{
Prepared for: \\ The U.S. Environmental Protection Agency \\ Prepared by: \\ Karen R. Newlon, Karissa M. Ramstead, and Jamul Hahn \\ Montana Natural Heritage Program \\ a cooperative program of the \\ Montana State Library and the University of Montana
}

October 2013

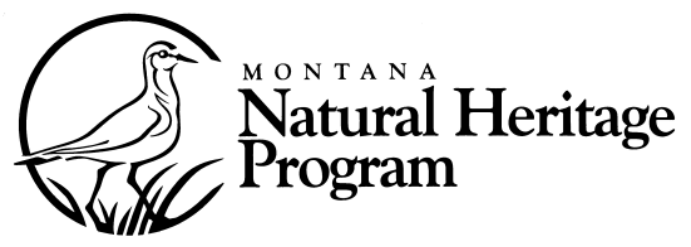




\section{Southeast Montana Wetland Assessment: Developing and Refining Montana's Wetland Assessment and Monitoring Strategy}

Prepared for:

The U.S. Environmental Protection Agency

Agreement Number:

CD-97868401-0

Prepared by:

Karen R. Newlon, Karissa M. Ramstead, and Jamul Hahn
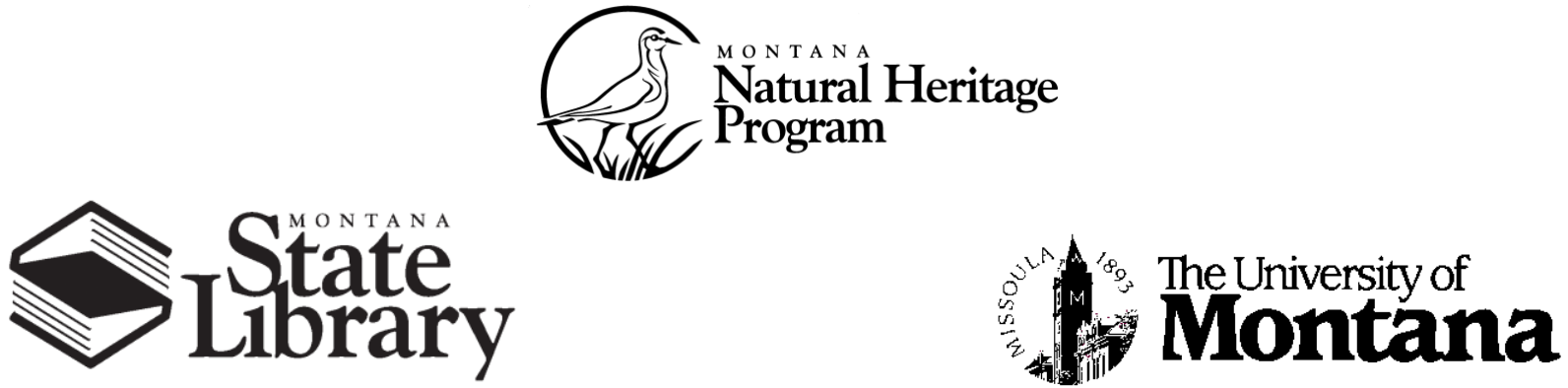

C2013 Montana Natural Heritage Program

P.O. Box $201800 \bullet 1515$ East Sixth Avenue • Helena, MT 59620-1800 • 406-444-5354 
This document should be cited as follows:

Newlon, Karen R., Karissa M. Ramstead, and Jamul Hahn. 2013. Southeast Montana Wetland Assessment: Developing and Refining Montana's Wetland Assessment and Monitoring Strategy. Report to the U.S. Environmental Protection Agency. Montana Natural Heritage Program, Helena, Montana. 43 pp. plus appendices. 


\section{EXECUTIVE SUMMARY}

Wetlands provide multiple biological and economic benefits such as plant and wildlife habitat, flood attenuation, groundwater recharge, and improvements to water quality. Despite these benefits, wetlands continue to experience pressures from multiple uses including urban, exurban, and agricultural development, as well as resource extraction. Quantifying the impact of these uses on wetland resources requires scientifically sound metrics to assess wetland condition.

This report summarizes the results of our third statewide rotating basin assessment, focusing on wetlands in southeastern Montana. We assessed wetland condition within nine watersheds at multiple spatial scales. We conducted Level 1 GIS analyses that produced: 1) wetland landscape profiles, which summarize information on wetland abundance, type, and extent within a given watershed; and 2) a landscape characterization, which characterizes the anthropogenic stressors such as roads and land uses, as well as general information regarding wetland landscape context, using readily available digital datasets. We carried out Level 2 assessments to provide rapid, field-based assessments of wetland condition based on four attributes: 1) Landscape Context; 2) Vegetation; 3) Physicochemical; and 4) Hydrology. Finally, Level 3 intensive assessments provided detailed information on the structure and composition of wetland vegetation at a subset of sites. This multi-tiered framework allows for the incorporation of multiple scales of assessment, integrating landscape-level information, ambient wetland condition, and site-specific data.

We included all digitally mapped wetlands to produce wetland landscape profiles for the project area. For the Level 1 landscape characterization and Level 2 and Level 3 wetland assessments, the target population included all mapped palustrine wetlands greater than 0.1 ha. We followed a spatially balanced sampling approach to select wetlands for assessment.

For Level 1 values and Level 2 assessment scores, we calculated descriptive statistics and assessed the range and distribution of each metric by examining frequency histograms. For Level 3 assessments, we calculated multiple vegetation metrics to conduct a floristic quality assessment (FQA). The FQA accounts for the presence of both native and exotic species, as well as individual plant species' tolerance of disturbance. We determined the relationships between Level 3 vegetation metric values, Level 2 assessment scores, and stressors recorded at assessment sites by examining Spearman's correlation coefficients.

Based on digital mapping, wetlands and other waterbodies within the study area totaled 78,529 acres (31,780 hectares). These totals include deepwater areas such as lakes and river channels, which provide critical aquatic habitat and other valuable ecosystem services but are not considered wetlands. The majority $(71 \%)$ of the mapped acres are palustrine wetlands.

We conducted a Level 1 landscape characterization of 1,000 mapped palustrine wetland polygons at three spatial scales: 100-m, 300-m, and 1,000-m envelopes around each polygon. Most wetland polygons selected were surrounded by natural vegetation classes at all spatial scales. Anthropogenic land uses at these scales were mostly cultivated crops or pasture/hay with minor areas of commercial and residential development. 
We visited 83 sites during the summer of 2011. Of these, 16 wetlands did not meet the criteria for further assessment, so 67 wetlands were sampled using the MTNHP EIA protocol. Western North American Emergent Marsh was the most common system sampled (45 sites). Western Great Plains Open Freshwater Depression was the second most commonly sampled ecological system (19). We sampled two sites classified as Western Great Plains Saline Depression and one site classified as Northwestern Great Plains Riparian Woodland and Shrubland. Each wetland system had a unique suite of associated plant species.

Level 2 condition scores were calculated for all 67 wetlands sampled. Scores ranged from 49-93 out of a possible range of 21.5-100. We divided our assessment scores into four categories defined relative to their departure from reference standard. Most sites (47 sites) fell into the slight to moderate departure from reference condition category.

Only 17 sites had no observed stressors in the assessment area (AA), whereas only 15 sites had no observed stressors within the 200-m envelope. Livestock grazing and unpaved roads were the most common stressors potentially impacting Landscape Context and Vegetation for both the AA and the 200-m envelope. Hydrologic stressors were observed at $48 \%$ of AAs and $57 \%$ of 200-m envelopes, due largely to impoundments and berms creating reservoirs or stock ponds. Sites had few observed Physicochemical stressors.

We completed 19 Level 3 intensive assessments within the project area, encountering 161 plant taxa. The average number of species encountered per site was 18 (range 1-45). Of the 140 taxa identified to species, $111(79 \%)$ were native species and 29 were exotic species. We calculated FQA metrics for all 19 Level 3 assessment sites. Mean C-value across these sites was 3.18 (range 1.55-6.00). Most $\mathrm{C}$-values for native species encountered fell between 3 and 5, indicating that most species observed at sites had some degree of habitat specificity with a moderate tolerance to disturbance.

To understand the effectiveness of this assessment framework in determining the condition of wetlands in the southeast Montana project area, we compared Level 3 assessment results with Level 2 assessment results. Stressor impact ratings within the 200-m envelope around the AA and within the AA showed moderate negative correlations with overall Level 2 assessment scores $(r=-0.49$ and $r=-0.58$, respectively). However, only the condition score for the Hydrologic attribute showed more than a weak correlation with stressor impacts ratings.

Of the 16 vegetation metrics evaluated in the FQA, only three were correlated with either stressors or overall wetland condition: cover of native graminoids, FQI of native species, and cover-weighted FQI of native species. Although some FQA metrics showed poor correlation with overall condition scores, they did show some weak to moderate correlations with individual Level 2 attribute scores. Non-native species richness showed a negative correlation with the Vegetation attribute score. Cover-weighted Mean C-value of all species showed a positive correlation with both the vegetation and Physicochemical attribute scores. Mean C-value of native species showed poor correlation with all Level 2 attributes as well as stressors and overall condition score. All FQA metrics showed poor correlation with the Hydrologic attribute score. 
Results from this project indicate the wetlands sampled in southeast Montana are in good to fair condition. Scores were lowest for Physicochemical and Hydrologic attributes across ecological systems. Livestock grazing, unpaved roads, impoundments of flowing water, and reservoir/stock ponds were the most commonly encountered stressors. 


\section{ACKNOWLEDGMENTS}

This project was funded by a U.S. Environmental Protection Agency Region 8 Wetland Program Development Grant. We would like to thank Toney Ott of EPA Region 8 for her continued support and commitment to wetland assessment and monitoring in our region. We thank Maya Daurio, Natalie Kashi, Sara Owen, and Nick Smith for spending long days in the field collecting data for this project. Maya Daurio also completed digital wetland mapping that was integral to the completion of this project. Joanna Lemly of the Colorado Natural Heritage Program provided helpful suggestions for data analyses and interpretation. Linda Vance of MTNHP provided useful comments on an earlier draft of this report. Any errors or omissions in the report are entirely the responsibility of the authors. 


\section{TABLE OF CONTENTS}

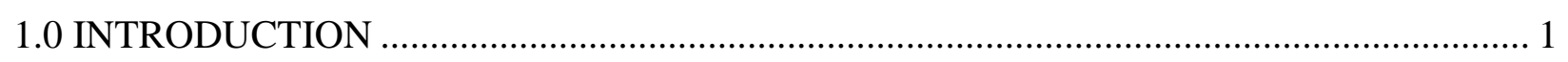

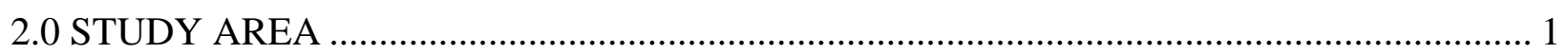

2.1 Geography

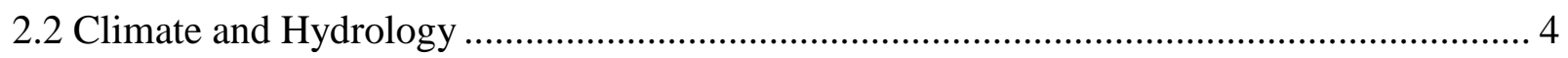

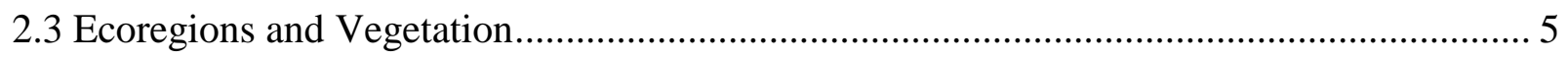

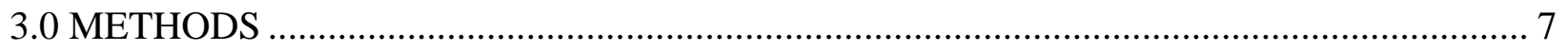

3.1 Ecological Integrity Assessment Framework .................................................................. 7

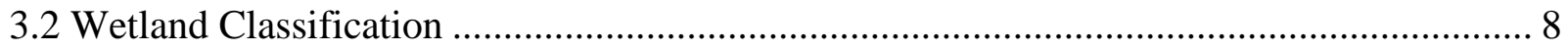

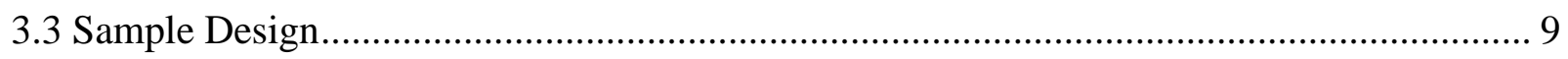

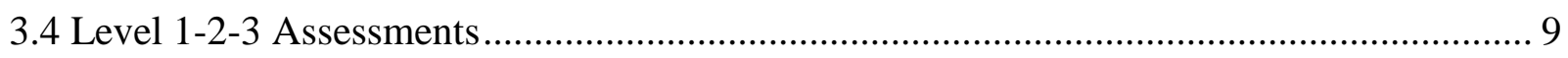

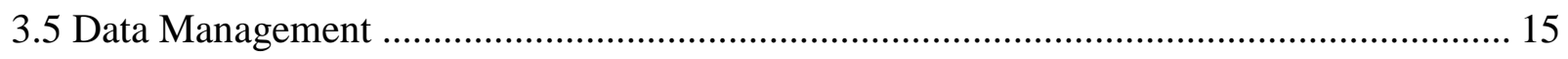

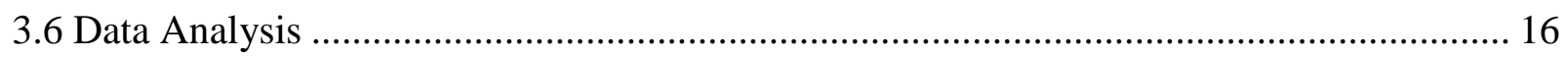

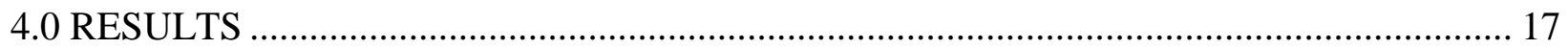

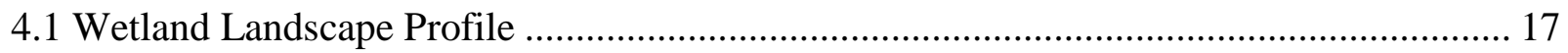

4.2 Level 1 Landscape Characterization ................................................................................ 19

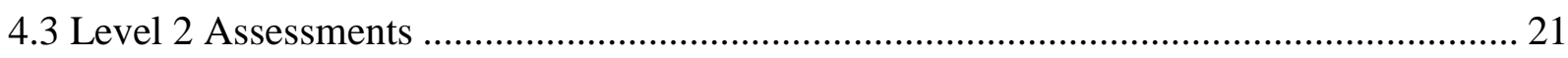

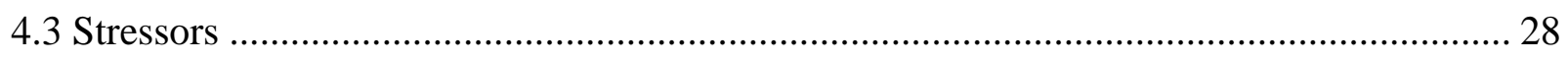

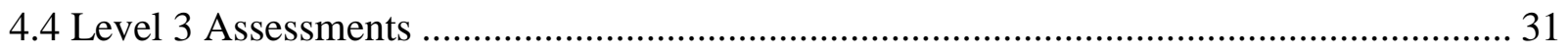

4.5 Floristic Quality Assessment..................................................................................... 32

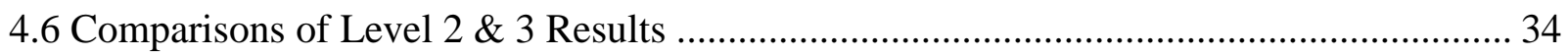

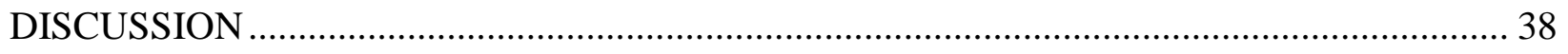

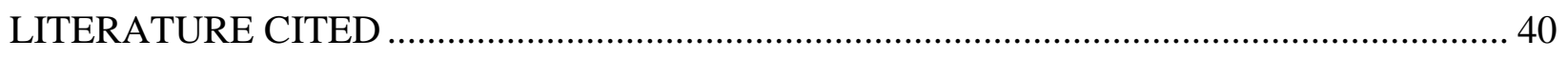

Appendix A. National Wetland Inventory (NWI) attribute codes included in the southeastern

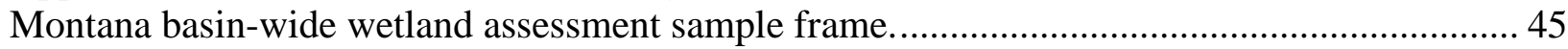

Appendix B. Palustrine National Wetland Inventory (NWI) attribute codes excluded from the southeastern Montana basin-wide wetland assessment sample frame.

Appendix C. Lacustrine and riverine National Wetland Inventory (NWI) attribute codes excluded from the southeastern Montana basin-wide wetland assessment sample frame..

Appendix D. Scoring procedure for calculating stressor impact ratings (sensu Faber-Langendoen

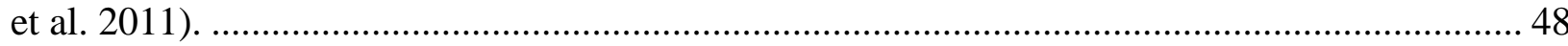

Appendix E. Scoring formulas for Level 2 attribute and overall wetland condition scores......... 49 Appendix F. Terminology, description, and calculation of the floristic quality assessment metrics. 
Appendix G. Wetland landscape profile for palustrine wetlands in the southeast Montana basinwide assessment project area.

\section{LIST OF TABLES}

Table 1. Land area of watersheds included in the southeast Montana basin-wide assessment project.

Table 2. Level IV Ecoregions and their corresponding land area within the southeast Montana basin-wide assessment project area.

Table 3. Ecological Integrity Assessment metrics and ecological attributes used in the southeast Montana basin-wide assessment project. .................................................................... 8

Table 4. Stressor metrics and associated disturbance categories............................................. 12

Table 5. Scope and severity ratings for stressors observed within the assessment area (AA) and within a 200-m envelope around the AA.

Table 6 . Area (ha; $\pm 1 \mathrm{SD}$ ) of land cover and land use around selected wetlands within $100 \mathrm{~m}$, $300 \mathrm{~m}$, and 1,000 m envelopes around the wetland by Cowardin wetland class.

Table 7. Sampled wetlands by Ecological System in the southeast Montana basin-wide assessment project area.

Table 8. Sampled wetlands by hydrogeomorphic system in the southeast Montana basin-wide assessment project area.

Table 9. Wetland condition category by wetland ecological system for the southeast Montana basin-wide assessment project area. Condition categories are interpreted as: at or near reference standard; slight departure from reference standard; moderate departure from reference standard; and severe departure from reference standard. 26

Table 10. Ecological Integrity Assessment (EIA) attribute condition category by wetland ecological system for the southeast Montana basin-wide assessment project area. Condition categories are interpreted as: at or near reference standard; slight departure from reference standard; moderate departure from reference standard; and severe departure from reference standard.

Table 11. Stressors observed in the assessment area (AA) and the 200-m envelope around the AA and the corresponding number of sampled wetland sites, categorized by Ecological Integrity Assessment (EIA) attribute. Note that some stressors are considered to impact more than one attribute.

Table 12. Count of overall assessment area (AA) stressor impact ratings by wetland ecological system for the southeast Montana basin-wide assessment project area.

Table 13. Overall stressor impact rating within the $200-\mathrm{m}$ envelope around the assessment (AA) by wetland ecological system for the southeast Montana basin-wide assessment project area.... 29

Table 14. Ecological Integrity Assessment (EIA) attribute stressor impact rating within the assessment area (AA) by wetland ecological system for the southeast Montana basin-wide assessment project area. 
Table 15. Ecological Integrity Assessment (EIA) attribute stressor impact rating within the 200m envelope around the assessment area (AA) by wetland ecological system for the southeast Montana basin-wide assessment project area.

Table 16. Five most commonly encountered plant species during Level 3 intensive assessments in the southeast Montana basin-wide assessment project area.

Table 17. Means and standard deviations of all floristic quality assessment (FQA) metrics considered by Ecological System for Level 3 assessments completed in the southeast Montana basin-wide assessment project area.

Table 18. Spearman's correlation coefficients of Impact Category scores calculated within a 200m envelope of the assessment area with Level 2 assessment attribute and overall scores.

Table 19. Spearman's correlation coefficients of Impact Category scores calculated within the assessment area (AA) with Level 2 assessment attribute and overall scores.

Table 20. Spearman's correlation coefficients of metrics included in the floristic quality assessment (FQA). Correlation coefficients of 0.90 or greater are in bold. 36

Table 21. Vegetation metrics included in the floristic quality assessment (FQA), and their response to stressors within the assessment area (AA), within the 200-m envelope surrounding the AA, and their relationship with overall wetland condition scores. Response categories are defined as follows: poor correlation refers to metrics with weak correlation $(r<0.3)$ with stressors at either scale and/or overall condition scores. Correlated indicates metrics that show a response $(r \geq 0.3)$ to either stressors and/or overall wetland condition scores. FQA metrics that were highly correlated $(r \geq 0.9)$ with other FQA metrics were not considered.

Table 22. Spearman's correlation coefficients of floristic quality assessment (FQA) metrics with Level 2 assessment attribute scores. FQA metrics that were highly correlated $(r \geq 0.9)$ with other FQA metrics were not considered.

\section{LIST OF FIGURES}

Figure 1. Southeastern Montana basin-wide assessment project area. .................................... 2

Figure 2. Land ownership within the southeast Montana basin-wide assessment project area ...... 3

Figure 3. Extent of the Powder River Basin within the southeastern Montana project area. ........ 4

Figure 4. Relative effective annual precipitation (REAP) for the southeast Montana basin-wide

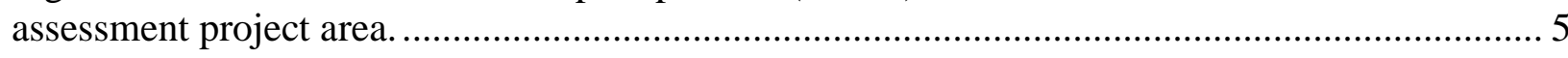

Figure 5. Level IV Ecoregions within the southeast Montana basin-wide assessment project area.

Figure 6. Broad land cover and land use classes of the southeast Montana basin-wide assessment project area (MTNHP 2013). Areas classified as recently disturbed or modified represent areas

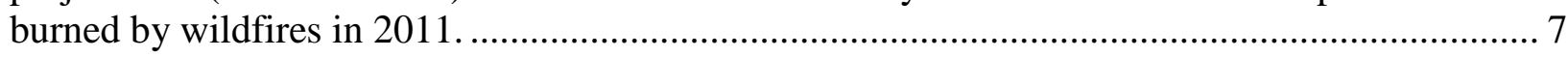

Figure 7. Example plot photos from wetland condition assessments in southeast Montana........ 13

Figure 8. Reléve plot layout (adapted from Peet et al. 1998)................................................ 15 
Figure 9. Percent of mapped wetland acres by Cowardin system in the southeast Montana basin-

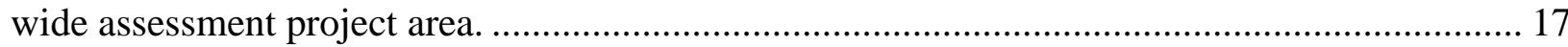

Figure 10. Percent of mapped wetland acres by Cowardin class in the southeast Montana basin-

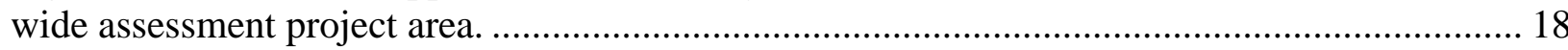

Figure 11. Percent of mapped wetland acres by Cowardin water regime in the southeast Montana basin-wide assessment project area. 18

Figure 12. Proportion of mapped wetlands classified as anthropogenically altered by Cowardin system in the southeast Montana basin-wide assessment project area. 19

Figure 13. Sampled wetlands by land ownership in the southeast Montana basin-wide assessment project area.

Figure 14. A Western North American Emergent Marsh sampled as part of the southeast Montana basin-wide assessment project. 23

Figure 15. A Western Great Plains Open Depression Wetland sampled as part of the southeast Montana basin-wide assessment project.

Figure 16. A Western Great Plains Saline Depression Wetland sampled as part of the southeast Montana basin-wide assessment project.

Figure 17. A Western Great Plains Riparian Woodland and Shrubland sampled as part of the southeast Montana basin-wide assessment project.

Figure 18. Level 2 assessment condition categories for wetlands assessed as part of the southeast Montana basin-wide assessment. Condition categories are relative to reference standard. 25

Figure 19. Frequency distribution of C-values of plant species encountered during Level 3 assessments in the southeast Montana basin-wide assessment project. 


\subsection{INTRODUCTION}

Wetlands provide multiple biological and economic benefits such as plant and wildlife habitat, flood attenuation, groundwater recharge, and improvements to water quality. Despite these benefits, wetlands continue to experience pressures from multiple uses including urban, exurban, and agricultural development, as well as resource extraction. Quantifying the impact of these uses on wetland resources requires scientifically sound metrics to assess wetland condition. Recognizing the need for information on wetland condition at a watershed scale, the Montana Natural Heritage Program (MTNHP) initiated a statewide monitoring and assessment program in 2008 to report on the ambient condition of Montana's wetlands. These basin-wide assessments provide regionally specific information on the ecological integrity of wetlands.

This report summarizes the results of our third basin-wide assessment of wetlands in southeastern Montana. Southeastern Montana has extensive areas of intact grassland and sagebrush steppe communities with a long history of livestock grazing. Aquatic resources in this part of the state are limited, making up less than $1 \%$ of the total land area. As a result, many wetlands and seasonal streams in the area have been modified to provide water for livestock. Despite these modifications, these areas continue to provide crucial habitat for fish, waterfowl, amphibians, and other wildlife.

Resource extraction is also a major land use in southeastern Montana. The Powder River Basin (PRB), which covers portions of the project area, has been a significant coal-producing area for nearly a century. However, the development of techniques to extract coalbed methane (CBM) has led to a rapid increase in natural gas production in the region. Although most production is currently located in Wyoming's portion of the PRB, the potential for increased CBM development in Montana exists and with it come potential impacts to groundwater and surface water quantity and quality.

Our objective was to assess wetland condition within nine watersheds in southeastern Montana at multiple spatial scales. We conducted Level 1 GIS analyses that produced: 1) wetland landscape profiles, which summarize information on wetland abundance, type, and extent within a given watershed; and 2) a landscape characterization, which characterizes the anthropogenic stressors such as roads and land uses, as well as general information regarding wetland landscape context, using readily available digital datasets. We conducted Level 2 assessments to provide rapid, field-based assessments of wetland condition. Finally, Level 3 intensive assessments provided detailed information on the structure and composition of wetland vegetation. This multi-tiered framework allows for the incorporation of multiple scales of assessment, integrating landscapelevel information, ambient wetland condition, and site-specific data.

\subsection{STUDY AREA}

\subsection{Geography}

The study area includes nine watersheds (Figure 1): Upper Tongue River (10090101), Lower Tongue River (10090102), Middle Powder River (10090207), Little Powder River (10090208), 
Lower Powder River (10090209), Mizpah Creek (10090210), O'Fallon Creek (10100005), Upper Little Missouri River (10110201), and Little Missouri River (10110202).

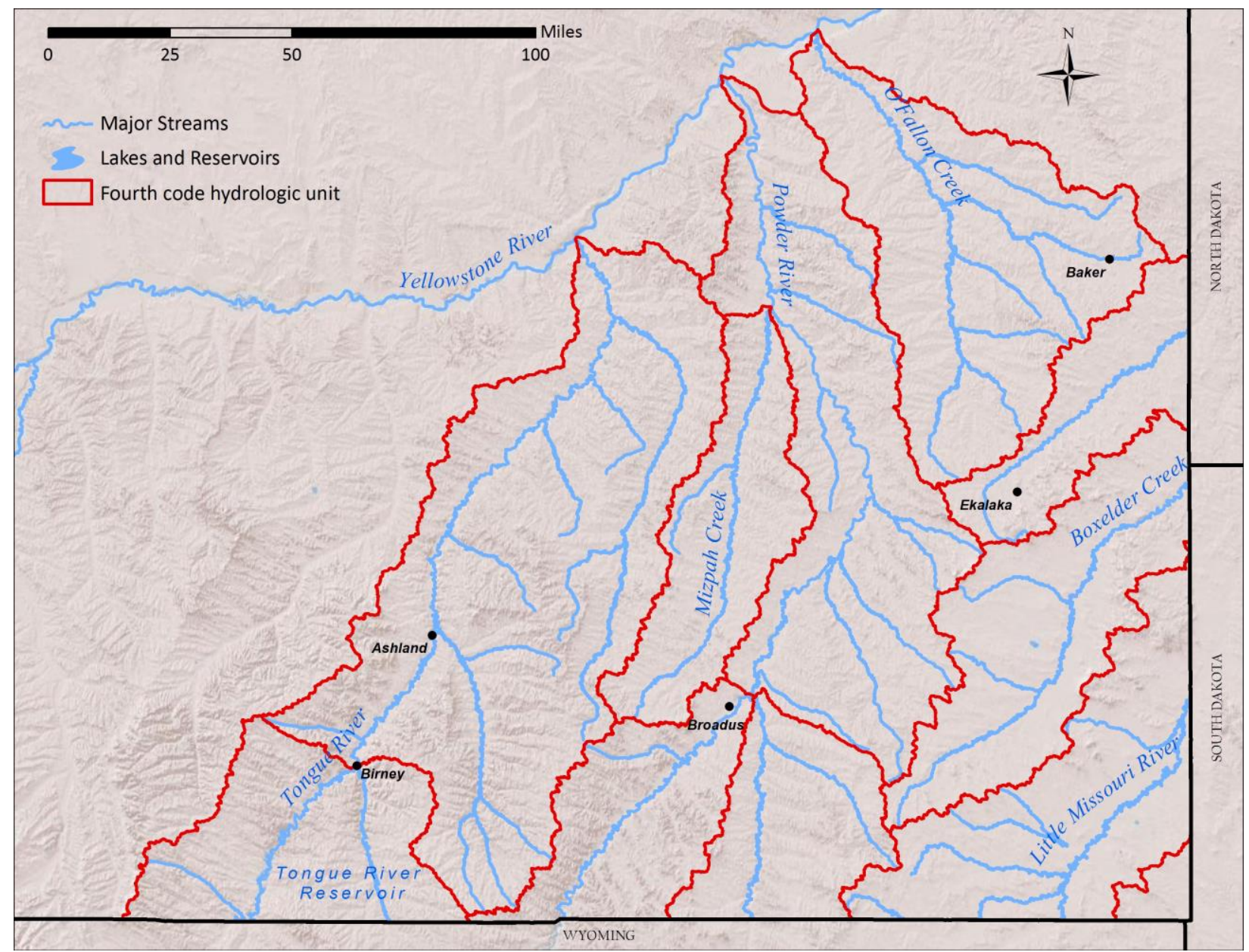

Figure 1. Southeastern Montana basin-wide assessment project area.

The project area covers 7,882,359 ac (3,189,891 ha) and includes portions of Prairie, Custer, Rosebud, Fallon, Carter, Big Horn, and Powder River counties (Table 1). Major towns in the project area include Ashland, Broadus, Baker, and Ekalaka. Most of the study area is privately owned, although lands owned by the Bureau of Land Management and U.S. Forest Service make up large portions of the area. The Crow and Northern Cheyenne Reservations cover portions of the eastern edge of the study area (Figure 2).

Southeastern Montana consists of extensive rangelands, and livestock grazing has been the predominant land use for well over a century. About half of the study area occurs within the Powder River Basin (PRB), which extends south into Wyoming (Figure 3). The PRB contains the single largest source of coal mined in the United States (Engle et al. 2012). 
Table 1. Land area of watersheds included in the southeast Montana basin-wide assessment project.

\begin{tabular}{lcrrc}
\hline Watershed & $\begin{array}{c}\text { 8-digit } \\
\text { hydrologic } \\
\text { unit code }\end{array}$ & \multicolumn{1}{c}{ Acres } & Hectares & $\begin{array}{c}\text { \% } \\
\text { Project }\end{array}$ \\
\hline Boxelder Creek (Little Missouri R) & 10110201 & 732,790 & 296,551 & $9 \%$ \\
Little Powder River & 10090209 & 417,214 & 168,841 & $5 \%$ \\
Lower Powder River & 10100004 & $1,200,638$ & 485,883 & $15 \%$ \\
Lower Tongue River & 10100001 & $1,837,425$ & 743,583 & $23 \%$ \\
Middle Powder River & 10090209 & 456,757 & 184,844 & $6 \%$ \\
Mizpah Creek & 10090209 & 513,935 & 207,983 & $7 \%$ \\
O'Fallon Creek & 10100004 & $1,010,003$ & 408,735 & $13 \%$ \\
Upper Little Missouri River & 10110203 & $1,125,583$ & 455,509 & $14 \%$ \\
Upper Tongue River & 10090102 & 588,015 & 237,962 & $7 \%$ \\
\hline
\end{tabular}

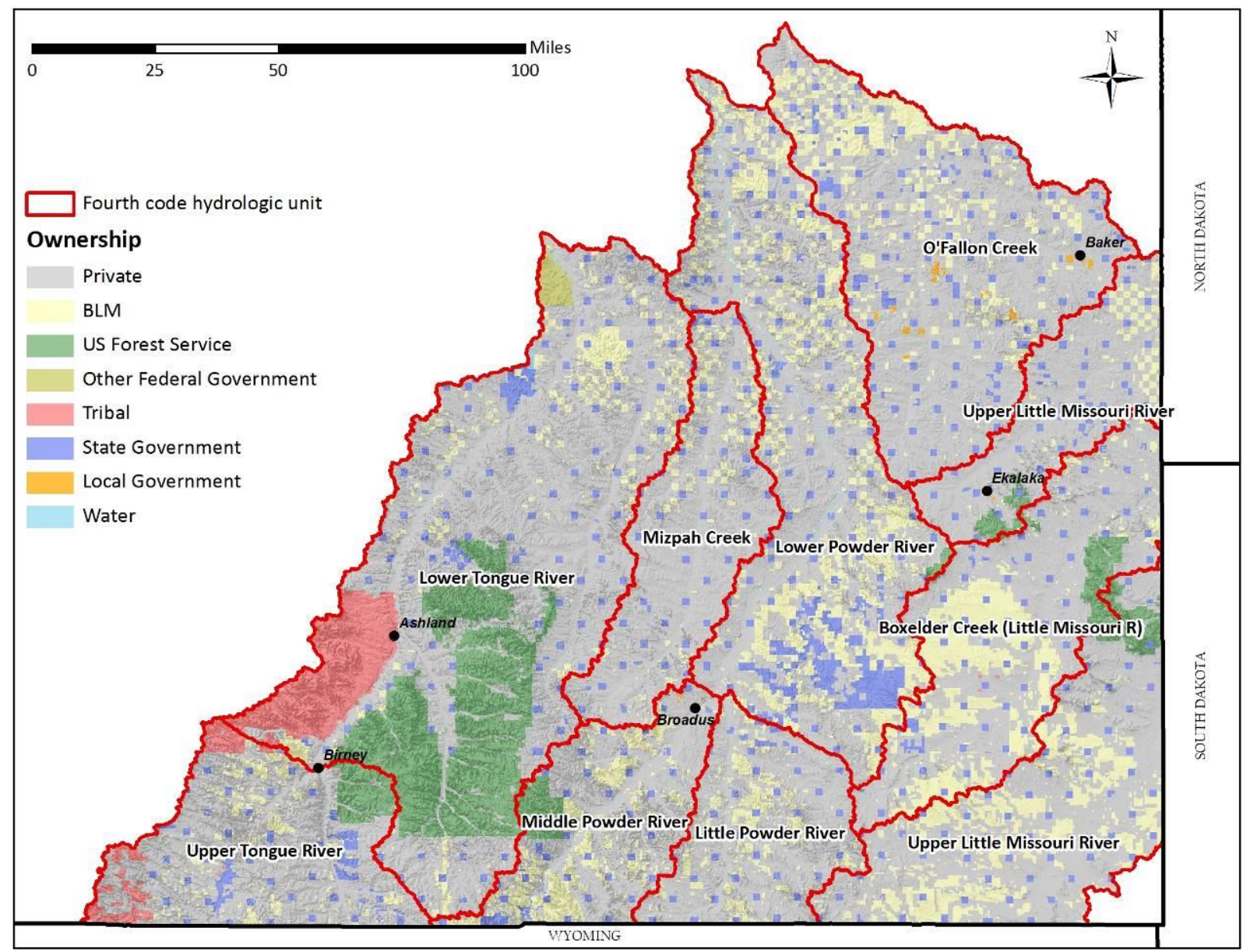

Figure 2. Land ownership within the southeast Montana basin-wide assessment project area

The topography of the study area ranges from gently rolling to deeply dissected plains that are interrupted by steep badlands and buttes. This unglaciated landscape was shaped largely by 
erosion of sedimentary deposits of sandstone, shale, bentonite, and lignite. Geology in the eastern portion of the study area is largely shale and claystones of the Pierre Shale Plains.

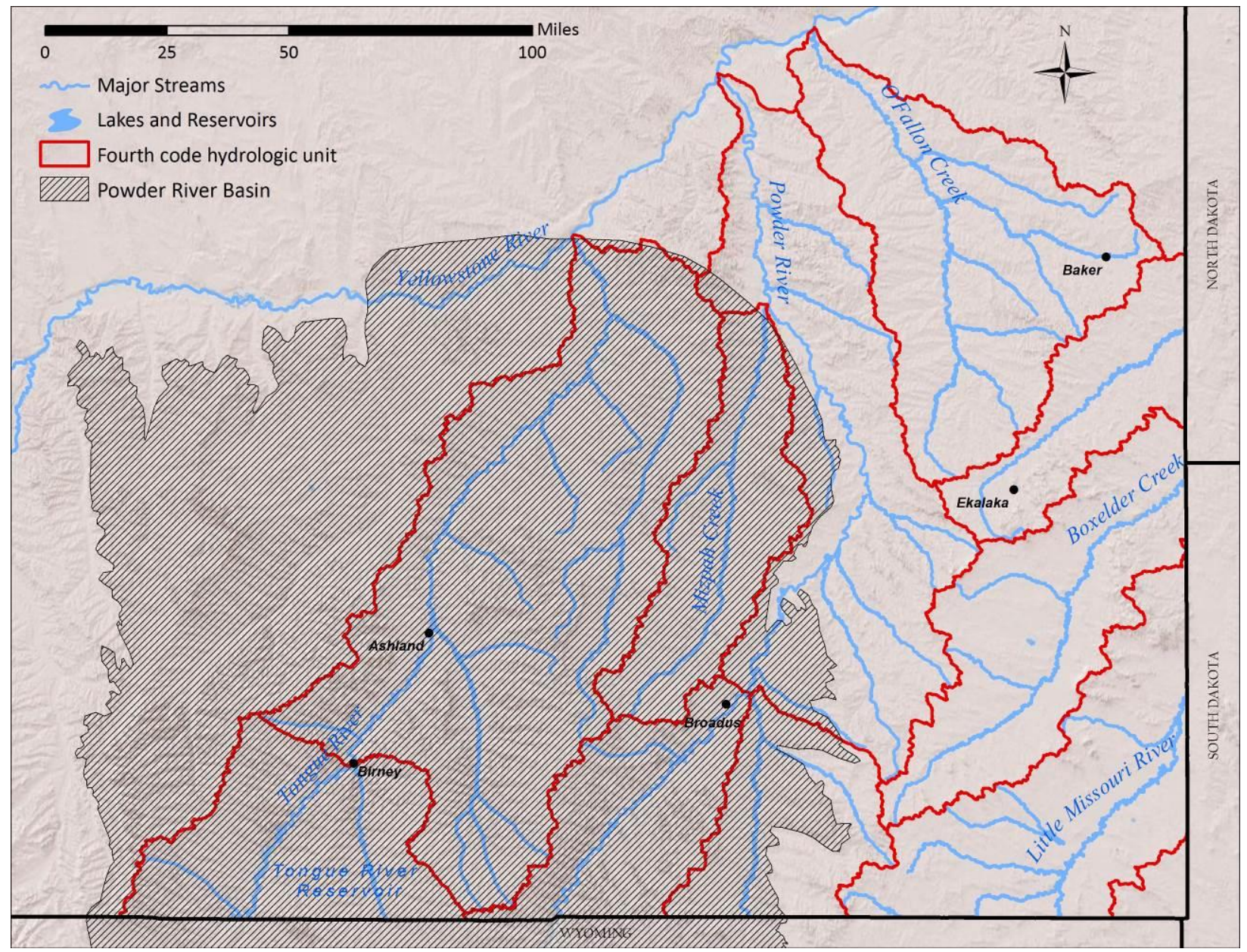

Figure 3. Extent of the Powder River Basin within the southeastern Montana project area.

\subsection{Climate and Hydrology}

The climate of the study area is continental and typical of the Great Plains with cold winters and warm, dry summers (McNab and Avers 1994). Average annual precipitation ranges from 11 to 15 inches (28 to $38 \mathrm{~cm}$ ), with peak precipitation periods occurring in May and June. Highest maximum daily temperatures occur during July and August with temperatures averaging $85^{\circ}$ to $88^{\circ} \mathrm{F}\left(29^{\circ}\right.$ to $\left.31^{\circ} \mathrm{C}\right)$. The relative effective annual precipitation (REAP), which is an indicator of the amount of moisture available at a given location accounting for precipitation, slope, aspect, and soil properties, ranges from a low of 9 inches $(24 \mathrm{~cm})$ in the breaks area in the northern portion of the study area to 22 inches $(55 \mathrm{~cm})$ in the buttes and mesic plains of the east and south (Figure 4).

Major rivers in the study area are the Powder and the Tongue Rivers, both of which begin in Wyoming and flow north into the Yellowstone River. The Little Missouri River flows across the southeastern portion of the study area into the Missouri River in North Dakota. Other major streams include O'Fallon Creek, Mizpah Creek, and Box Elder Creek. The Tongue River 
Reservoir is the largest reservoir in the study area. Many smaller reservoirs occur throughout the study area.

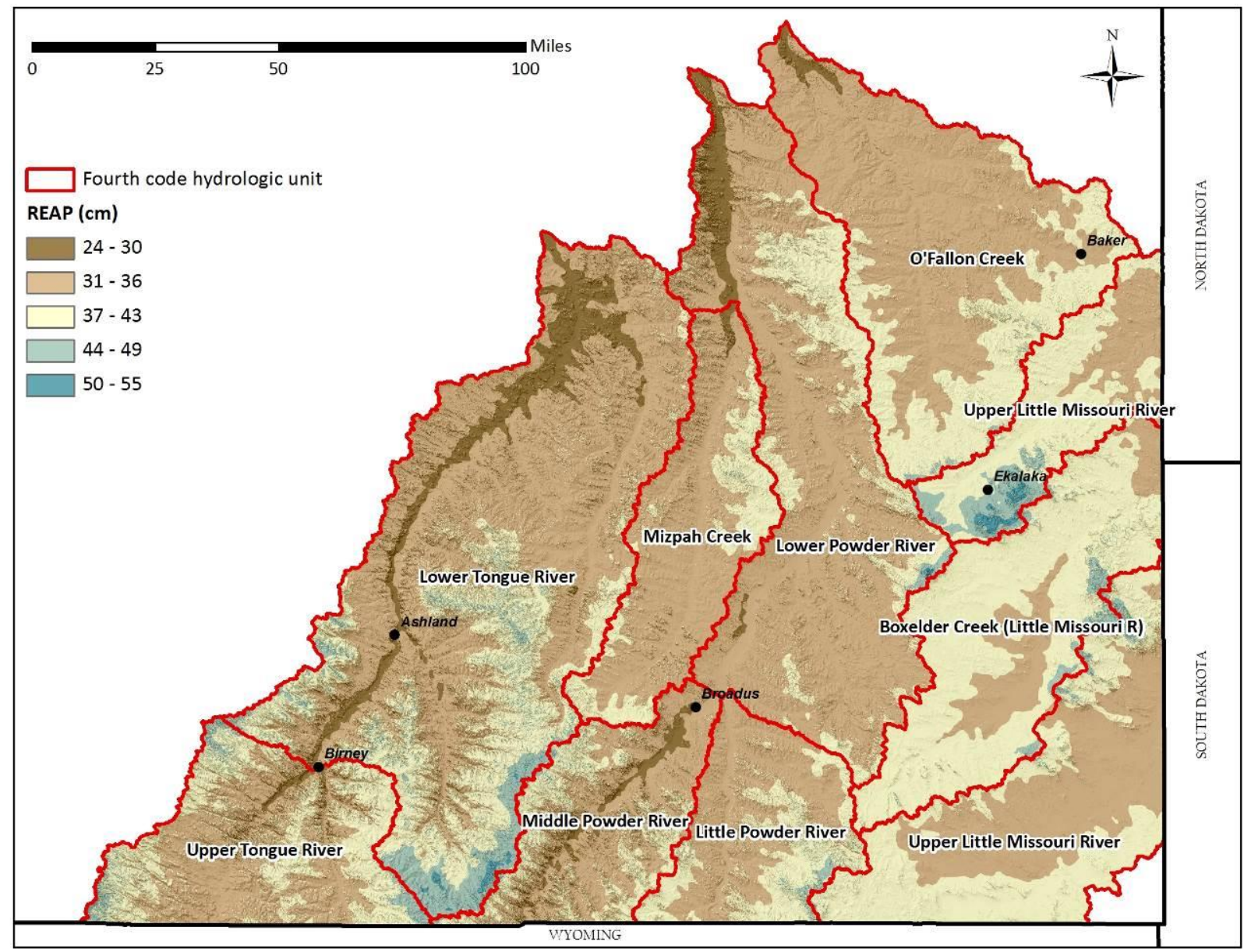

Figure 4. Relative effective annual precipitation (REAP) for the southeast Montana basin-wide assessment project area.

\subsection{Ecoregions and Vegetation}

The study area lies entirely within the Northwestern Great Plains Level III ecoregion (Omernik 1987). Level IV ecoregions further subdivide the area into 10 different units based on geology and dominant vegetation (Figure 5; Table 2). Vegetation is predominantly grasslands and sagebrush steppe (Figure 6). Grasslands of the study area are composed of wheatgrass (Pascopyrum/Elymus) - needlegrass (Nasella/Hesperostipa) or grama (Bouteloua) - needlegrass (Nasella/Hesperostipa) - wheatgrass (Pascopyrum/Elymus) vegetation associations. Buttes support Ponderosa pine (Pinus ponderosa) woodlands with wooded draws dominated by green ash (Fraxinus pennsylvanica) and boxelder (Acer negundo). Areas of sagebrush steppe dominated by Wyoming big sagebrush (Artemisia tridentata spp. wyomingensis) and Gardner's saltbush (Atriplex gardneri) occur in the southeastern portion of the study area. River breaks occur in the northern portion of the study area with Rocky Mountain juniper (Juniperus scopulorum) and green ash and boxelder on the north-facing slopes of draws. 


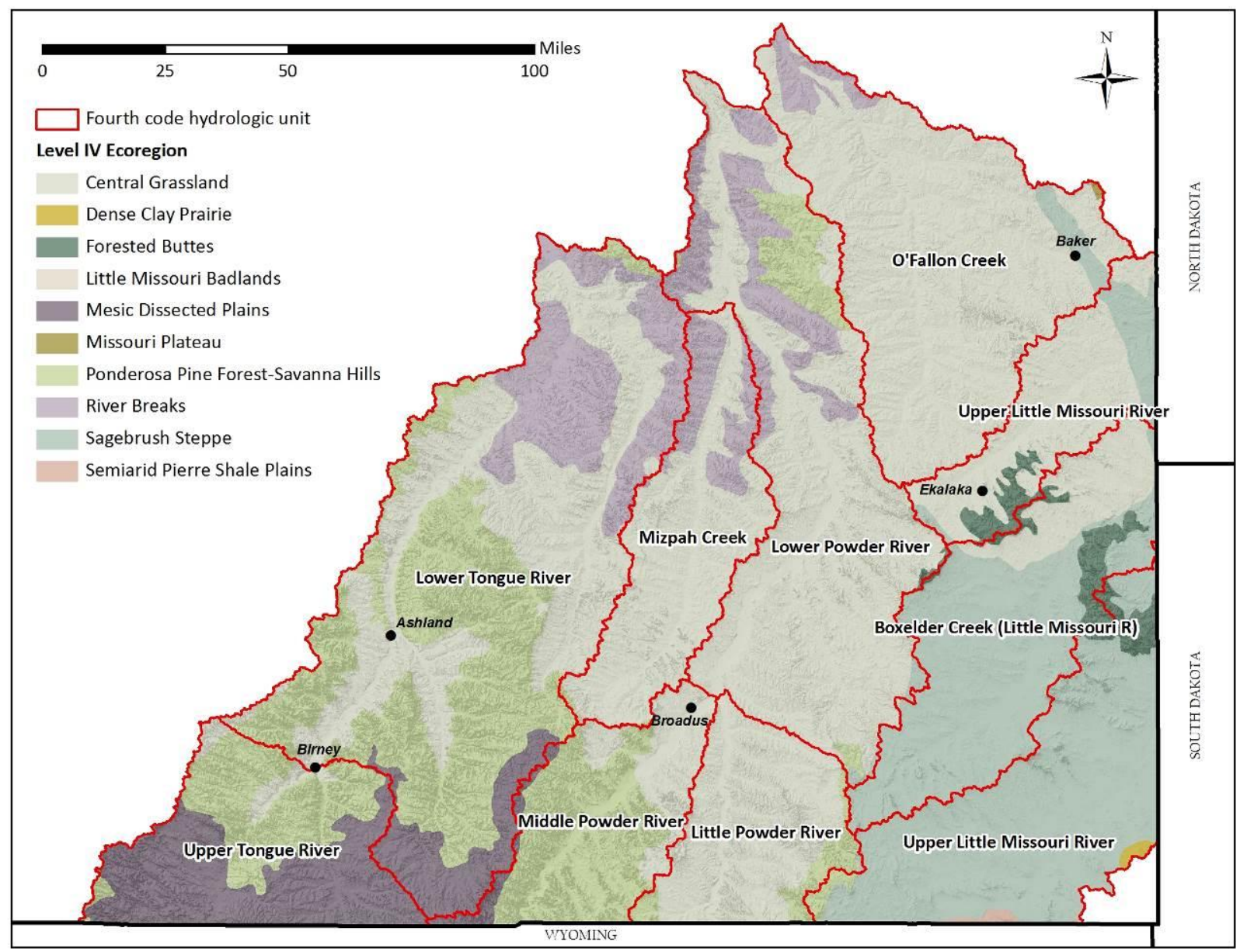

Figure 5. Level IV Ecoregions within the southeast Montana basin-wide assessment project area.

Table 2. Level IV Ecoregions and their corresponding land area within the southeast Montana basin-wide assessment project area.

\begin{tabular}{lcrrr}
\hline Level IV Ecoregion Name & Code & \multicolumn{1}{c}{ Acres } & Hectares & $\begin{array}{c}\text { \% of Project } \\
\text { Area }\end{array}$ \\
\hline Central Grassland & $43 \mathrm{n}$ & $3,883,562$ & $1,571,628$ & $49.4 \%$ \\
Dense Clay Prairie & $43 \mathrm{k}$ & 6,519 & 2,638 & $0.1 \%$ \\
Forested Buttes & $43 \mathrm{~d}$ & 122,291 & 49,490 & $1.6 \%$ \\
Little Missouri Badlands & $43 \mathrm{~b}$ & 6,376 & 2,580 & $0.1 \%$ \\
Mesic Dissected Plains & $43 \mathrm{q}$ & 512,494 & 207,400 & $6.5 \%$ \\
Missouri Plateau & $43 \mathrm{a}$ & 1,590 & 643 & $0.0 \%$ \\
Ponderosa Pine Forest-Savanna Hills & $43 \mathrm{p}$ & $1,358,883$ & 549,923 & $17.3 \%$ \\
River Breaks & $43 \mathrm{c}$ & 650,884 & 263,404 & $8.3 \%$ \\
Sagebrush Steppe & $43 \mathrm{e}$ & $1,314,708$ & 532,046 & $16.7 \%$ \\
Semiarid Pierre Shale Plains & $43 \mathrm{~g}$ & 10,009 & 4,050 & $0.1 \%$ \\
\hline
\end{tabular}




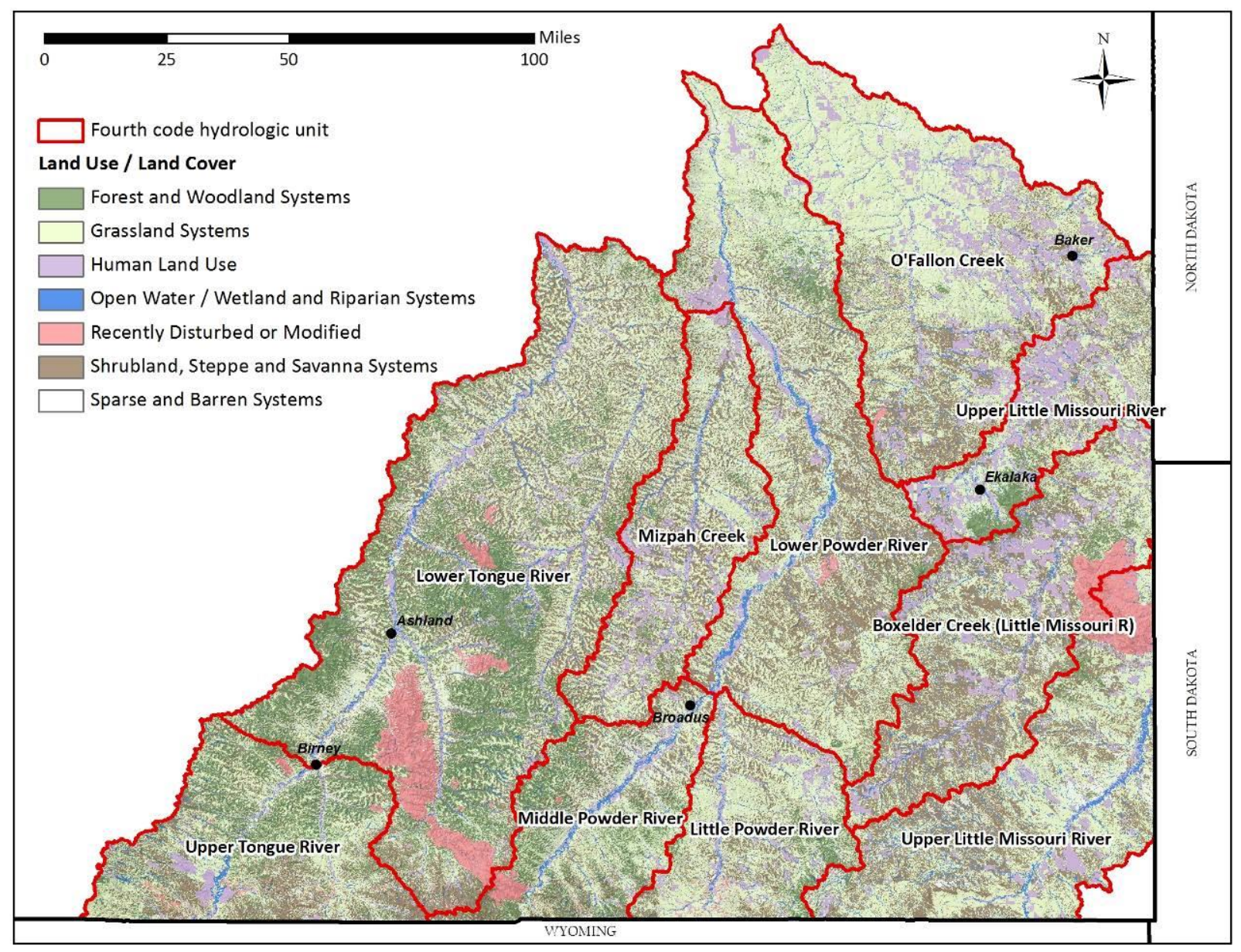

Figure 6. Broad land cover and land use classes of the southeast Montana basin-wide assessment project area (MTNHP 2013). Areas classified as recently disturbed or modified represent areas burned by wildfires in 2011.

\subsection{METHODS}

\subsection{Ecological Integrity Assessment Framework}

The MTNHP uses an Ecological Integrity Assessment (EIA) framework to assess the condition of wetlands. This EIA framework is based on one developed by NatureServe and ecologists from several Natural Heritage Programs across the country (Faber-Langendoen et al. 2011). This framework also applies concepts from established wetland assessment methods, including the California Rapid Assessment Method for Wetlands (CWMW 2013) and the Ohio Rapid Assessment Method (Mack 2001). An EIA relies upon the identification of key ecological indicators or metrics and stressors that can be readily measured, monitored, or observed. The indicators reflect both the structure and function of the wetland. Metrics consist of narrative ratings and are scaled along a gradient reflecting wetland condition relative to a natural or undisturbed state (i.e., reference standard). Ideally, metrics should be unambiguous, mutually exclusive, and equally distributed along a disturbance gradient, allowing the observer to best describe the observed state (Sutula et al. 2006). Metric ratings are assigned on an ordinal scale, 
resulting in reduced measurement error and repeatable results. EIA metric ratings are integrated to produce overall scores for four attributes: 1) Landscape Context; 2) Vegetation; 3)

Physicochemical; and 4) Hydrology. The ratings for these four attributes can be combined to produce an overall EIA score (Table 3).

We assessed wetland integrity at three levels. Level 1 GIS landscape analyses consist of: 1) wetland landscape profiles, which use digital wetland mapping to summarize information on wetland abundance, type, extent, and function across the watershed (Johnson 2005); and 2) a landscape characterization of the distribution of anthropogenic stressors such as roads and land use in relation to wetlands, as well as general information regarding wetland landscape context. Level 2 field-based assessments collect data on the general condition of individual wetlands. Level 3 assessments collect detailed quantitative data using indices of biological integrity.

Table 3. Ecological Integrity Assessment metrics and ecological attributes used in the southeast Montana basin-wide assessment project.

\begin{tabular}{ll}
\hline Attribute & Metric \\
\hline Landscape Context & Landscape Connectivity \\
& Buffer Width \\
& Buffer Length \\
& Buffer Condition \\
Vegetation & Relative Cover of Native Plant Species \\
& Relative Cover of Tolerant Native Plant Species \\
& Relative Cover of Noxious Plant Species \\
& Herbaceous Litter/Woody Debris Accumulation \\
& Interspersion of Plant Zones \\
& Woody Species Establishment and Regeneration \\
& Utilization of Trees and Shrubs \\
& Soil Surface Integrity \\
& Water Quality: Algae, Plants, and Turbidity \\
& Water Inputs \\
& Water Outlets \\
& Hydroperiod \\
& Surface Water Connectivity \\
\hline
\end{tabular}

\subsection{Wetland Classification}

Natural variability occurs both within wetland classes (e.g., wet meadows can occur at either alpine or lower montane elevations but differ in plant diversity and productivity) and among wetland classes (e.g., fens differ in hydrology, soils, and plant communities from freshwater marshes). Providing a classification framework to distinguish wetland systems helps reduce within class variability and enhance detection of differences in condition among wetlands. Common wetland classification systems include the Cowardin classification system (Cowardin et al. 1979) and the hydrogeomorphic (HGM) classification system (Brinson 1993). Standardized classifications have also been developed through the National Vegetation Classification (NVC; 
Grossman et al. 1998) and the Ecological Systems classification in the United States (Comer et al. 2003). For the purpose of this project, we used the Ecological Systems classification. This classification system provides a valuable means of classifying wetland systems because it uses both biotic (e.g., vegetation physiognomy and floristics) and abiotic (e.g., geologic, hydrologic, elevation, edaphic) criteria to define landscape units. Ecological Systems can be crosswalked to other classification systems including the NVC, Cowardin, and HGM systems. Additionally, they capture the range of natural variability in wetlands while organizing them into manageable conceptual units.

\subsection{Sample Design}

The MTNHP completed digital wetland mapping for the project area based on 2005 aerial imagery via a companion project funded by a previous EPA Wetland Program Development Grant. We included all digitally mapped wetlands to produce wetland landscape profiles for the project area. For the Level 1 landscape characterization and Level 2 and Level 3 wetland assessments, the target population included all mapped vegetated wetlands and excluded lacustrine (deepwater lakes), riverine (deepwater habitats contained with the channel), and artificially flooded wetlands from the target population. We also excluded wetlands smaller than 0.1 ha. A list of NWI types included in the sample frame can be found in Appendix A. A list of NWI types excluded from the sample frame can be found in Appendices B and C.

The target number of sample sites was 1,000 wetlands for Level 1 landscape characterization; 100 wetlands for Level 1 and 2 assessments; and 30 wetlands for Level 3 assessment. We followed a spatially balanced sampling approach (see Stevens and Olsen 2004, Stevens and Jensen 2007) to select wetlands for assessment. This approach allowed us to account for the spatial patterning inherent in ecological systems (e.g., sites in close proximity tend to be more similar than widely separated sites). Spatially balanced sampling is also more efficient than simple random sampling by minimizing the redundancy inherent in a simple random sample, which might select multiple proximate sites (Stevens and Jensen 2007). The sample design followed a Generalized Random Tessellation Stratified (GRTS) procedure for discrete objects with reverse hierarchical randomization, where polygons within the sample frame were the discrete objects and their locations were identified by their centroids. We selected approximately 1,000 wetlands, stratifying by Level IV ecoregion. GRTS sampling was performed using package spsurvey (Kincaid and Olsen 2009) in R (R Development Core Team 2009). After this initial site selection, we examined each selected wetland using aerial imagery in a GIS to ensure it still existed and was accessible until we had approximately 100 wetlands selected for Level 2 field assessments. We conducted intensive Level 3 assessments at approximately $30 \%$ of these 100 wetlands.

\subsection{Level 1-2-3 Assessments}

3.4.1 Level 1 - Wetland Landscape Profiling: Using digital wetland mapping, we prepared a wetland landscape profile for the project area. A wetland landscape profile provides a broad landscape characterization of the wetlands within a particular area at the basin, watershed, or subwatershed level. The profile summarizes wetland acreage by: Cowardin system, class, and 
hydrologic regime; land ownership; and the extent of wetlands that have been anthropogenically altered.

3.4.2 Level 1 - Landscape Characterization: We selected a spatially balanced random sample of 1,000 palustrine wetlands from digital wetland mapping. We used a reclassified Montana Land Cover and Land Use data layer (MTNHP 2013) to estimate land cover and land use values around these selected wetlands at three spatial scales: $100 \mathrm{~m}, 300 \mathrm{~m}$, and 1,000 m.

3.4.3 Level 2 Rapid Assessments: Field methods for Level 2 assessments are detailed in the Montana Ecological Integrity Assessment Field Manual (MTNHP 2011). Level 2 assessments take half a day or less to complete. At each sample wetland point, we established an assessment area (AA) for sampling. The AA was established within a portion of the wetland representing the same Ecological System type within a 0.5 ha area around the sample point. Prior to field visits, we created a set of field maps for each targeted sample point. The field maps outlined the potential AA boundary and multiple radial buffers around the AA. These buffers are used in several of the landscape context metrics.

Once at the target sample point, field team members determined the extent of the AA by estimating the approximate boundaries of the wetland within the potential AA. Readily observable ecological criteria such as vegetation, soil, and hydrological characteristics were used to define wetland boundaries, regardless of whether they met jurisdictional criteria for wetlands regulated under the Clean Water Act (sensu U.S. Army Corps of Engineers 2010). Because certain field metrics vary by Ecological System, every attempt was made to include a single Ecological System in the AA. If the target sample point occurred at the edge of a wetland or at the edge of one Ecological System type, then field teams adjusted the point up to $60 \mathrm{~m}$.

The EIA form also contains a list of observed stressors or disturbances commonly found in Montana (Table 4). Stressor lists can provide additional information when evaluating ecological integrity and can aid in further understanding of overall wetland condition. In some cases, stressors may be present at or near a site, but condition metrics may not reflect these impacts. This may be caused by a temporal lag between the impact and its effect on the biotic community, such as a very recent clear cut. Or it may reflect stressors the current biotic metrics do not pick up. In the first case, the stressor list can be used to flag sites that may become degraded in the future. In the second case, the stressor list may indicate that adjustments should be made to the metrics.

Along with recording the occurrence of a stressor, the scope and severity of each stressor were also estimated (Faber-Langendoen et al. 2011; Table 5). Scope is defined as the proportion of the occurrence of an ecosystem that can be expected to be affected by the stress. Severity is the level of damage to the site from the stressor that can be expected with continuation of current circumstances. Stressor scope and severity scores are rolled up into an overall stressor impact score (Appendix D). 
In addition to the EIA indicator metrics and observed stressors, we also collected standard site variables at each sample location. These included:

- UTM coordinates

- Elevation, slope, and aspect

- Ecological System classification (Comer et al. 2003)

- Dominant plant species

- HGM classification (Hauer et al. 2002)

- Cowardin classification (Cowardin et al. 1979)

- Nearby landforms (alluvial fans, narrow bedrock valley, alluvial valley, etc.)

- Description of onsite and adjacent ecological processes and land use

- Description of general site characteristics and a site drawing

- Selected soils data: depth and identification of soil horizons, texture, and color

- Water table depth 
Table 4. Stressor metrics and associated disturbance categories.

\begin{tabular}{|c|c|}
\hline Transportation Disturbances & Land Use Disturbances-Vegetation Removal \\
\hline Paved surfaces (e.g., roads, parking lots) & Chemical vegetation control \\
\hline Unpaved roads & Evidence of intentional burning \\
\hline Railroads & Vegetation conversion \\
\hline $\begin{array}{l}\text { Land Use Disturbances-Development or } \\
\text { Recreation }\end{array}$ & Natural or Environmental Disturbances \\
\hline Domestic or commercial development & Beetle-killed Pinus species \\
\hline Intensively managed sports fields, golf courses & Other diseased conifers \\
\hline Recreation or human visitation & Evidence of recent fire ( $<5$ years) \\
\hline Filling or dumping of sediment or fill & Beaver activity \\
\hline Trash or refuse dumping & Evidence of prolonged drought \\
\hline & $\begin{array}{l}\text { Browsing of woody vegetation by native } \\
\text { ungulates }\end{array}$ \\
\hline Hydrologic Disturbances & Land Use Disturbances-Agriculture \\
\hline \multirow{11}{*}{$\begin{array}{l}\text { Upstream spring box } \\
\text { Impoundment of flowing water } \\
\text { Potential for agricultural runoff } \\
\text { Potential for urban runoff } \\
\text { Upstream dam } \\
\text { Reservoir/Stock pond } \\
\text { Weir or drop structure } \\
\text { Dredged inlet/outlet channel } \\
\text { Engineered channel (e.g., riprap) } \\
\text { Pumps, diversions, or ditches that move water into } \\
\text { wetland } \\
\text { Pumps, diversions, or ditches that move water out } \\
\text { of wetland } \\
\text { Berms/Dikes/Levees }\end{array}$} & Dryland farming \\
\hline & Livestock grazing \\
\hline & Irrigated cropland \\
\hline & Irrigated hay pasture \\
\hline & Permanent tree plantation \\
\hline & $\begin{array}{l}\text { Disturbed fallow lands dominated by exotic } \\
\text { species }\end{array}$ \\
\hline & Haying of native grassland \\
\hline & Fallow fields (no human use in past 10 years) \\
\hline & Plowing or discing \\
\hline & Land Use Disturbances-Resource Extraction \\
\hline & $\begin{array}{l}\text { Gravel pits, open pit mining } \\
\text { Other mining activity or abandoned mines } \\
\text { Resource extraction (oil and gas) } \\
\text { Intensive logging ( } 50-75 \% \text { trees of }>50 \mathrm{~cm} \\
\text { diameter removed) } \\
\text { Selective logging }(<50 \% \text { of trees }>50 \mathrm{~cm} \\
\text { diameter removed) }\end{array}$ \\
\hline
\end{tabular}


Table 5. Scope and severity ratings for stressors observed within the assessment area (AA) and within a 200-m envelope around the AA.

\begin{tabular}{cl}
\hline Scope of Disturbances \\
\hline 5 & Pervasive - Affects nearly all $(>75 \%)$ of the envelope or AA. \\
4 & Large - Affects most $(>50-75 \%)$ of the envelope or AA. \\
3 & Moderate - Affects much $(>25-50 \%)$ of the envelope or AA. \\
2 & Restricted - Affects some $(>10-25 \%)$ of the envelope or AA. \\
1 & Small - Affects a small $(1-10 \%)$ portion of the envelope or AA. \\
0 & Nil - Little or no observed effect $(<1 \%)$ on the envelope or AA. \\
\hline Severity of Disturbances & Extreme - likely to extremely modify, degrade, destroy, or eliminate the wetland. \\
\hline 4 & Serious - likely to seriously modify, degrade or reduce wetland function or condition. \\
2 & Moderate - likely to moderately modify, degrade or reduce wetland function or condition. \\
1 & Slight - likely to only slightly modify, degrade, or reduce wetland function or condition. \\
\hline
\end{tabular}

At least four photos were taken from the AA center at each site (Figure 7). Photos were taken $90^{\circ}$ from each other, and the aspect was recorded to the nearest $5^{\circ}$ at all photo points. Photo placards were placed in the corner of each photo. Additional photos were taken as needed to document the wetland and surrounding landscape.

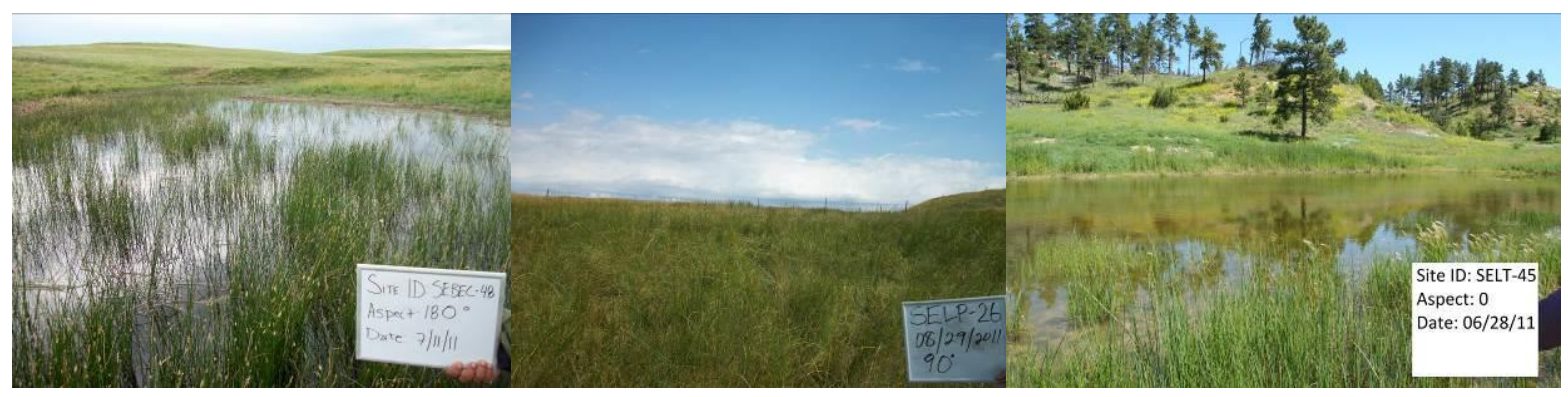

Figure 7. Example plot photos from wetland condition assessments in southeast Montana.

At each sampling location, we collected detailed soil data by excavating a soil pit $45-60 \mathrm{~cm}$ in depth. For each horizon, we recorded depth, soil layers, matrix color, redoximorphic feature color and abundance (\%), and soil texture. Soil color was determined using Munsell Soil Color Charts (Munsell Color Company 2000).

3.4.4 Level 3 Intensive Assessments: Field methods for Level 3 assessments are detailed in the Montana Ecological Integrity Assessment Field Manual (MTNHP 2011). We collected intensive Level 3 vegetation data at approximately $30 \%$ of sites using a $20 \mathrm{~m}$ x $50 \mathrm{~m}$ relevé plot (Peet et al. 1998). This method takes up to six hours per site. The method has been in use by the North Carolina Vegetation Survey for over 10 years (Peet et al. 1998) and has been used to successfully develop a vegetation index of biotic integrity (VIBI) in Ohio (Mack 2004) and Colorado (Rocchio 2006; Rocchio 2007; Lemly and Rocchio 2009). The structure of the plot consists of 10 $10 \mathrm{~m}$ x $10 \mathrm{~m}\left(100 \mathrm{~m}^{2}\right)$ modules typically arranged in a $20 \mathrm{~m}$ x $50 \mathrm{~m}$ array (Figure 8). The plot was subjectively placed within the AA to maximize abiotic/biotic heterogeneity. Capturing heterogeneity within the plot ensures adequate representation of local variations produced by 
hummocks, water tracks, side-channels, pools, wetland edge, microtopography, etc. The following guidelines were used to determine plot locations within the AA:

- The plot was located in a representative area of the AA that incorporates as much microtopographic variation as possible.

- If the AA was homogeneous and there was no direction or orientation evident in the vegetation, the plot was laid out to run either N-S or E-W using the second hand on a watch to randomly determine direction $(00-29 \mathrm{sec}=\mathrm{N}-\mathrm{S}$ orientation; $30-59 \mathrm{sec}=\mathrm{E}-\mathrm{W}$ orientation).

- If the AA was not homogeneous, was oddly shaped, or was directional (i.e., followed a stream), the plot was oriented to adequately represent all wetland features.

- If the wetland had an irregular shape and the $20 \mathrm{~m}$ x $50 \mathrm{~m}$ plot did not fit within the AA, the array of modules was restructured to accommodate the shape of the AA. For example, a $10 \mathrm{~m}$ x $50 \mathrm{~m}$ plot was used for narrow, linear areas and a $20 \mathrm{~m}$ x $20 \mathrm{~m}$ plot was used for small, circular sites.

- The plot captured the range of diversity within the AA, without crossing over into the upland. No more than $20 \%$ of the plot was located in upland areas beyond the wetland. If end modules crossed into the upland, they were not sampled as intensive modules.

- If a small patch of another wetland type was present in the AA (but not large enough to be delineated as a separate Ecological System), the plot was placed so at least a portion of the patch was in the plot.

- Localized, small areas of human-induced disturbance were included in the plot according to their relative representation of the AA.

Absolute cover of all vascular species was estimated within four of the $100 \mathrm{~m}^{2}$ modules, referred to as intensive modules. When all species within a module had been identified, cover was visually estimated for the $100 \mathrm{~m}^{2}$ module using the following cover classes (Peet et al. 1998):

Class $1=$ trace (one individual or two individuals)

Class $2<1 \%$

Class $3 \geq 1-2 \%$

Class $4 \geq 2-5 \%$

Class $5 \geq 5-10 \%$
Class $6 \geq 10-25 \%$

Class $7 \geq 25-50 \%$

Class $8 \geq 50-75 \%$

Class $9 \geq 75-95 \%$

Class $10 \geq 95 \%$ 


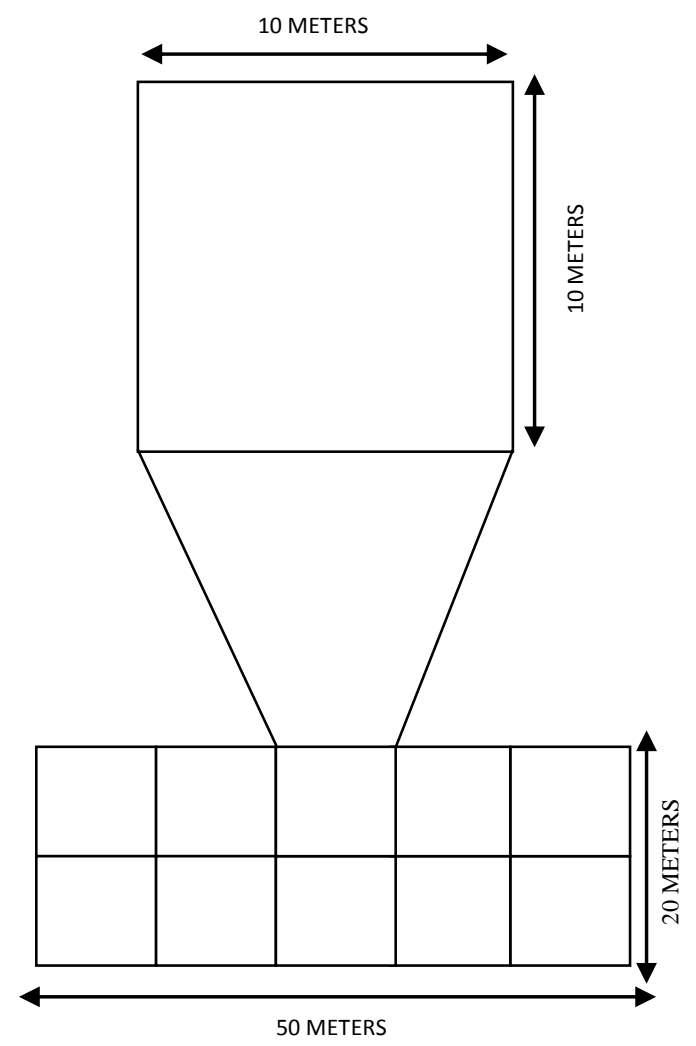

Figure 8. Reléve plot layout (adapted from Peet et al. 1998).

After sampling each of the intensive modules, the remaining, or residual, modules were walked to document presence of any species not recorded in the intensive modules. Percent cover of these species was estimated over the entire $1,000 \mathrm{~m}^{2}$ plot.

In the field, vascular plants were identified using the Vascular Plants of Montana (Dorn 1984) as well as ancillary dichotomous keys specific to certain plant genera (e.g., carices). The state-based nomenclature was crosswalked to nationally accepted nomenclature based on the USDA PLANTS Database (http://plants.usda.gov).

3.4.5 Intensive Assessment of Stressors: To capture the actual spatial extent of stressors observed within the 200-m envelope around the AA perimeter, we estimated the percent of the 200-m envelope affected by each stressor. For linear features such as roads, we estimated the length in meters of each stressor within the 200-m envelope.

\subsection{Data Management}

We created a relational database in Microsoft Access ${ }^{\circledR}$. All EIA data and vegetation plot data were entered into the database after field data collection was complete. For vegetation data, plant species mean cover values were averaged across modules to get an average cover value for each 
plant species for the entire vegetation plot. Unknown species or ambiguous species (e.g., Carex sp.) were entered into the database, but these were not included in data analysis.

\subsection{Data Analysis}

3.6.1 Level 2 Assessments: Scores were calculated for each site using metric narrative ratings and scoring formulas (Appendix E). A score was calculated for the site overall as well as separately for each major attribute.

We calculated descriptive statistics for and assessed the range and distribution of each metric by examining frequency histograms. We created correlation matrices using Spearman's correlation coefficients to investigate relationships and to evaluate any redundancy among metrics.

Similarly, we calculated Spearman's correlation coefficients of attribute scores and final wetland condition scores to determine the amount of variability explained by each attribute and each metric.

3.6.2 Level 3 Vegetation Assessments: We calculated multiple vegetation metrics (Appendix F) to conduct a floristic quality assessment (FQA). The FQA accounts for the presence of both native and exotic species, as well as individual plant species' tolerance of disturbance (Cronk and Fennessy 2001, Miller and Wardrop 2006). Coefficients of conservatism (C-values) are assigned to taxa identified to species and represent the relative tolerance of a species to disturbance, ranging from 0 to 10 (after Andreas et al. 2004). Native species that exhibit high degrees of ecological specificity and sensitivity to disturbance have C-values of 9-10. Native species that are typical of well-established communities that have undergone minimal disturbance have C-values of 6-8. Native species that have some degree of habitat specificity but can tolerate moderate disturbance have $\mathrm{C}$-values of 3-5. Widespread native species that occur in a variety of communities and are common in disturbed sites have values of 1-2. Finally, exotic species were assigned C-values of 0 . C-values have not been assigned specifically for wetland plant species in the Northern Great Plains of Montana, so C-values for plant species observed at southeast Montana wetland sites were taken from the Northern Great Plains Floristic Quality Assessment Panel (2001).

We also calculated a wetland index that is based upon species' wetland indicator status from the National Wetland Plant List (Lichvar 2012). Each wetland indicator status category was assigned a value from +2 (UPL) to -2 (OBL), representing a coefficient of wetness for each taxa identified to species. These coefficients of wetness are averaged and the mean is considered a wetness index. A wetness index of zero or less indicates a predominance of wetland species. Only native species are considered in this calculation, as exotic species tend to skew the distribution of wetland indicators towards upland categories (Herman et al. 1997).

We calculated descriptive statistics for and assessed the range and distribution of vegetation metrics by examining frequency histograms. We created correlation matrices using Spearman's correlation coefficients to investigate relationships and to evaluate any redundancy among metrics. We also used Spearman's correlation coefficients to evaluate the relationship of metrics to observed stressors as well as the ability of metrics to discriminate among wetland sites of varying condition. 


\subsection{RESULTS}

\subsection{Wetland Landscape Profile}

Based on digital mapping, wetlands and other waterbodies within the study area totaled 78,529 acres (31,780 hectares). These totals include deepwater areas such as lakes and river channels, which provide critical aquatic habitat and other valuable ecosystem services but are not considered wetlands. Mapped wetlands within the study area totaled 55,926 acres (22,633 hectares), comprising $0.7 \%$ of the land area. By system, the majority (71\%) of the mapped acres are palustrine wetlands (Figure 9). By class, freshwater emergent wetlands make up the majority (53\%) of wetland acres (Figure 10). By water regime, temporarily and seasonally flooded wetlands are the most common (Figure 11). These wetlands typically have surface water for a few days or weeks during the growing season but dry down later in the season.

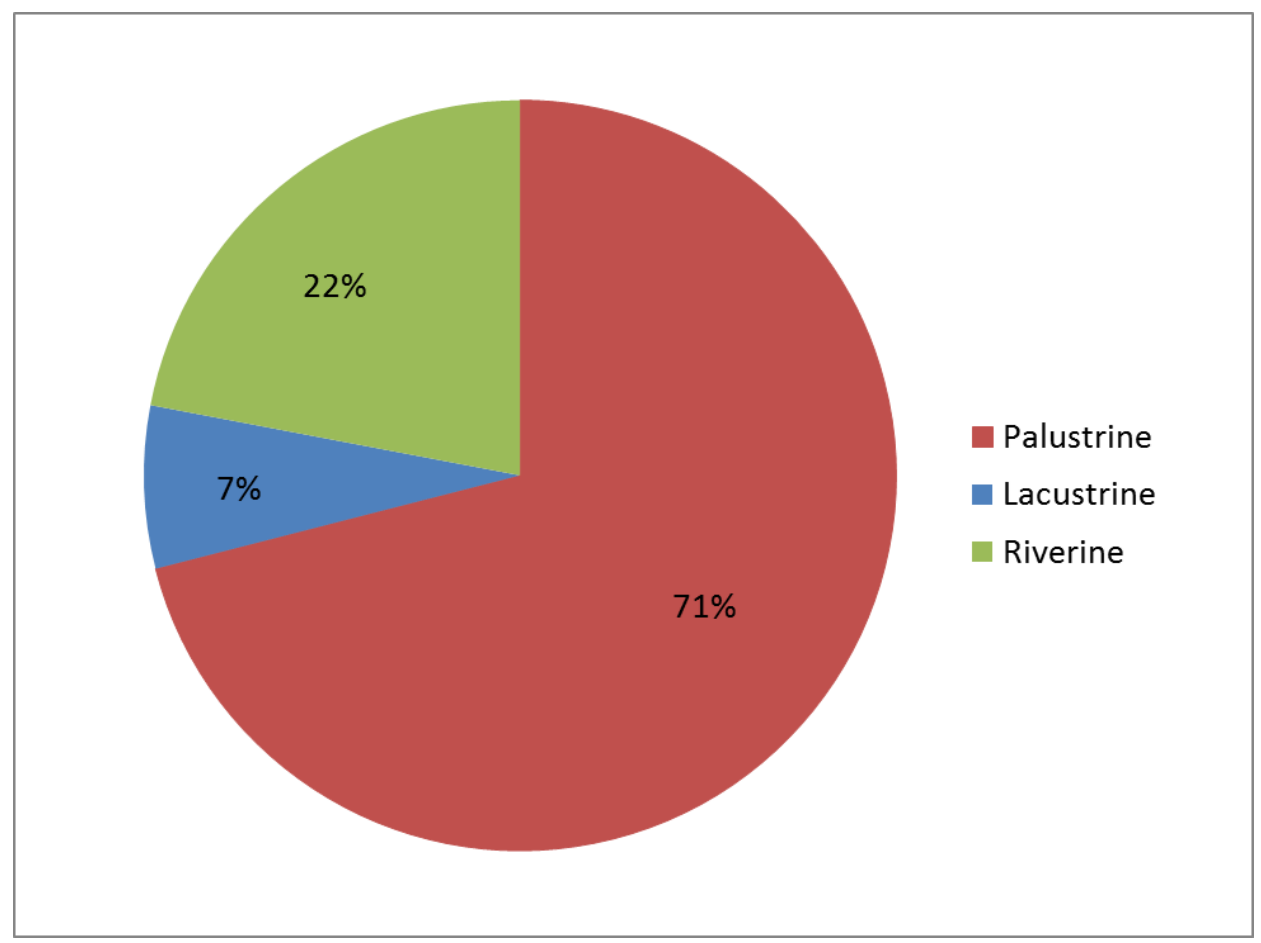

Figure 9. Percent of mapped wetland acres by Cowardin system in the southeast Montana basinwide assessment project area. 


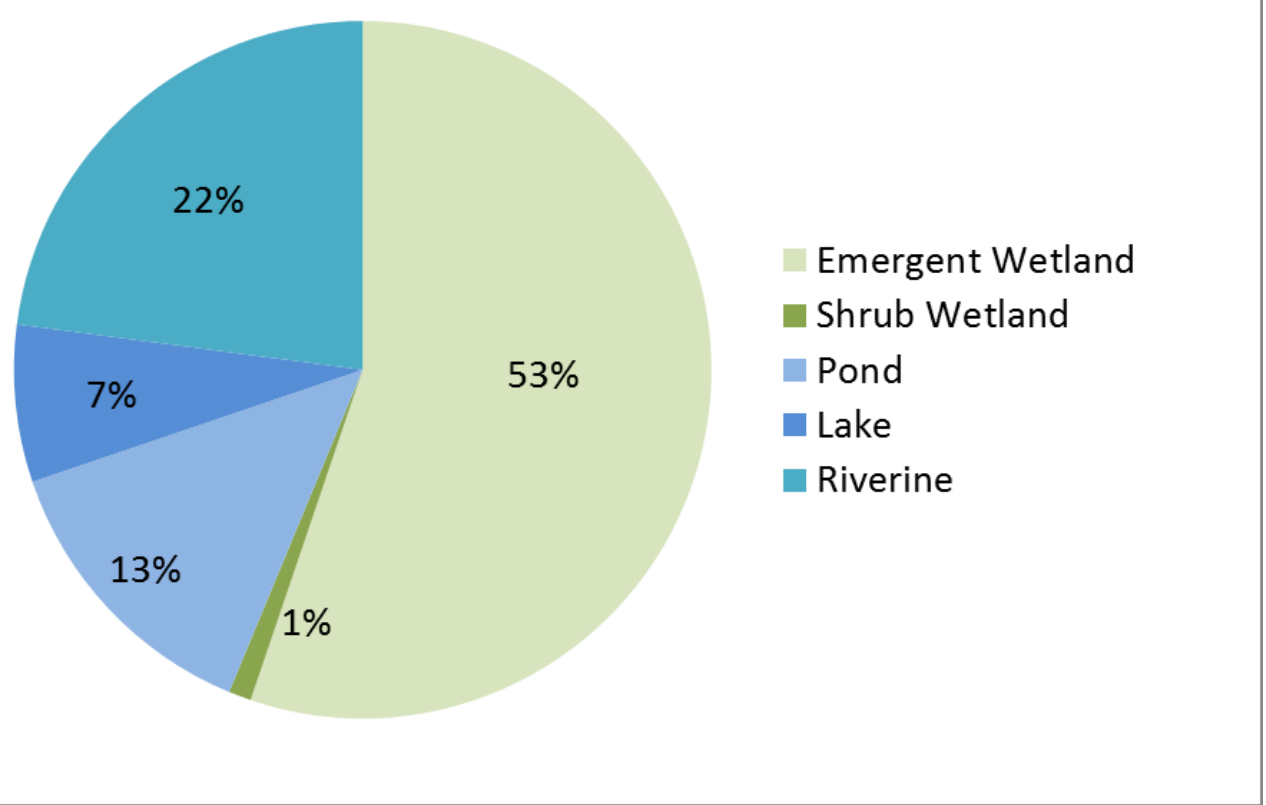

Figure 10. Percent of mapped wetland acres by Cowardin class in the southeast Montana basinwide assessment project area.

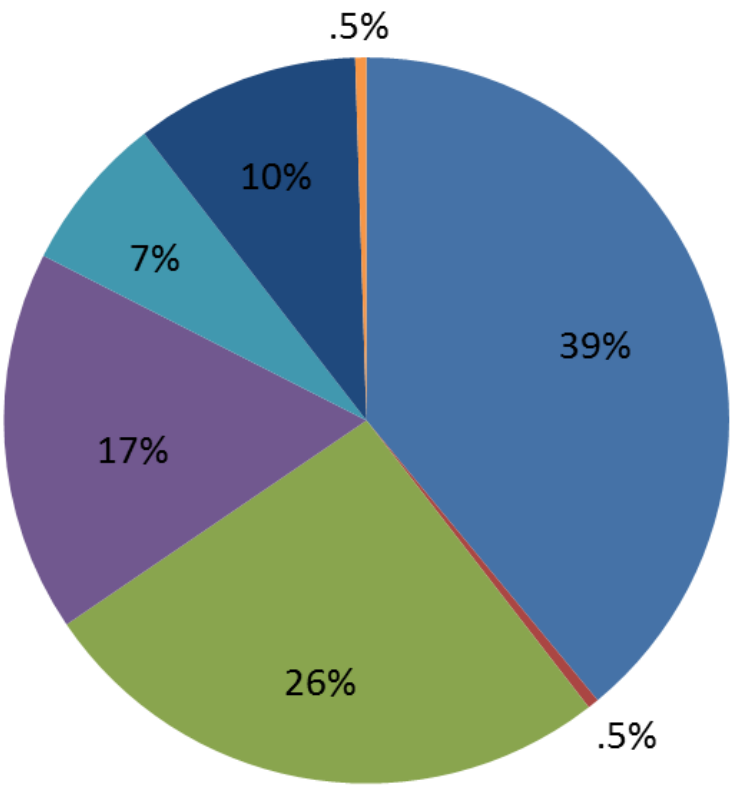

- Temporarily Flooded - A

- Saturated - B

Seasonally Flooded - C

- Semipermanently

Flooded - F

- Intermittently Exposed G

- Permanently Flooded $\mathrm{H}$

Artificially Flooded - K

Figure 11. Percent of mapped wetland acres by Cowardin water regime in the southeast Montana basin-wide assessment project area. 
Most anthropogenically altered wetlands in the project area fell into the Palustrine System, as these mapped wetland types represent reservoirs created by stream impoundments or excavated wetlands (Figure 12). Altered lacustrine wetlands represent large reservoirs created by stream impoundments. The spatial distribution of palustrine wetlands by watershed is included in Appendix G.

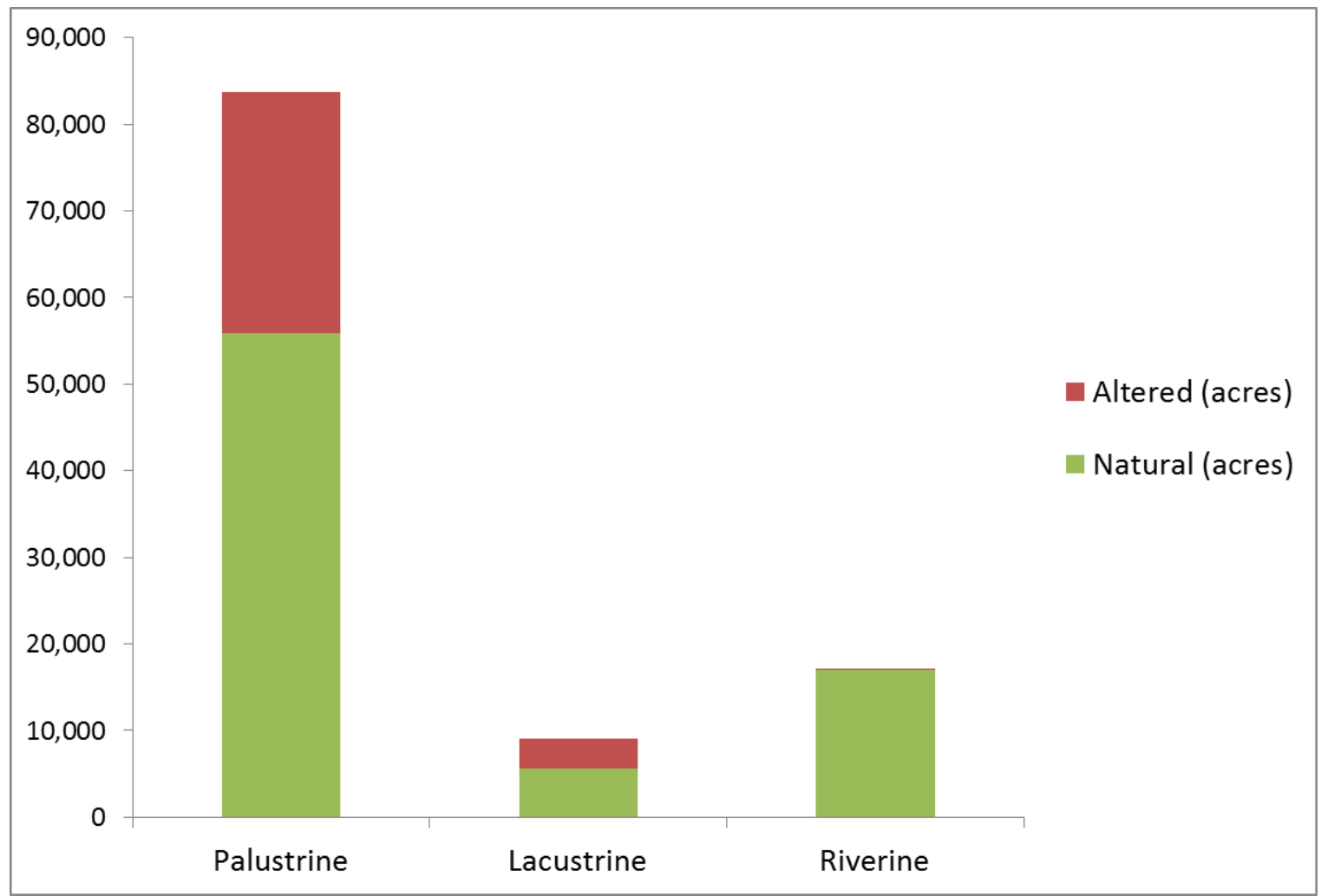

Figure 12. Proportion of mapped wetlands classified as anthropogenically altered by Cowardin system in the southeast Montana basin-wide assessment project area.

\subsection{Level 1 Landscape Characterization}

Most randomly selected wetland polygons were surrounded by natural vegetation classes at all three spatial scales (Table 6). Anthropogenic land uses at these scales were mostly cultivated crops or pasture/hay with minor areas of commercial and residential development. 
Table 6. Area (ha; \pm 1 SD) of land cover and land use around selected wetlands within $100 \mathrm{~m}, 300 \mathrm{~m}$, and 1,000 m envelopes around the wetland by Cowardin wetland class.

\begin{tabular}{|c|c|c|c|c|c|c|c|c|c|c|c|c|c|c|c|c|c|c|}
\hline & \multicolumn{6}{|c|}{100 m envelope } & \multicolumn{6}{|c|}{300 m envelope } & \multicolumn{6}{|c|}{$1,000 \mathrm{~m}$ envelope } \\
\hline & \multicolumn{2}{|c|}{ Aquatic Bed } & \multicolumn{2}{|c|}{ Emergent } & \multicolumn{2}{|c|}{ Scrub-shrub } & \multicolumn{2}{|c|}{ Aquatic Bed } & \multicolumn{2}{|c|}{ Emergent } & \multicolumn{2}{|c|}{ Scrub-shrub } & \multicolumn{2}{|c|}{ Aquatic Bed } & \multicolumn{2}{|c|}{ Emergent } & \multicolumn{2}{|c|}{ Scrub-shrub } \\
\hline & Mean & SD & Mean & SD & Mean & $\mathrm{SD}$ & Mean & SD & Mean & $\mathrm{SD}$ & Mean & SD & Mean & SD & Mean & SD & Mean & $\mathrm{SD}$ \\
\hline Natural Vegetation & 2.88 & 0.65 & 2.78 & 0.75 & 3.15 & 0.00 & 24.87 & 6.00 & 23.94 & 6.89 & 26.73 & 2.16 & 261.27 & 62.00 & 252.87 & 68.96 & 280.89 & 47.48 \\
\hline Resource Extraction & 0.00 & 0.01 & $*$ & $*$ & $*$ & $*$ & 0.01 & 0.03 & 0.00 & 0.02 & $*$ & $*$ & 0.07 & 0.30 & 0.03 & 0.19 & $*$ & $*$ \\
\hline Cultivated Crops & 0.11 & 0.45 & 0.17 & 0.54 & $*$ & $*$ & 1.35 & 4.18 & 2.24 & 5.41 & 0.18 & 0.25 & 16.41 & 34.93 & 27.45 & 49.49 & 19.89 & 28.13 \\
\hline Commercial/Industrial & $*$ & $*$ & 0.00 & 0.04 & $*$ & $*$ & 0.02 & 0.36 & 0.01 & 0.36 & $*$ & $*$ & 0.30 & 3.24 & 0.05 & 0.89 & $*$ & $*$ \\
\hline Developed Open Space & 0.00 & 0.01 & 0.00 & 0.01 & $*$ & $*$ & 0.02 & 0.27 & 0.02 & 0.40 & $*$ & $*$ & 0.22 & 2.08 & 0.11 & 1.47 & $*$ & $*$ \\
\hline High Intensity Residential & $*$ & $*$ & $*$ & $*$ & $*$ & $*$ & $*$ & $*$ & 0.00 & 0.01 & $*$ & $*$ & 0.02 & 0.16 & 0.01 & 0.19 & $*$ & $*$ \\
\hline Transportation & 0.02 & 0.13 & 0.03 & 0.16 & $*$ & $*$ & 0.28 & 0.77 & 0.28 & 0.78 & 0.63 & 0.89 & 3.08 & 5.31 & 2.84 & 4.88 & 7.74 & 10.95 \\
\hline Introduced Vegetation & 0.01 & 0.06 & 0.01 & 0.11 & $*$ & $*$ & 0.05 & 0.50 & 0.06 & 0.59 & 0.63 & 0.89 & 0.54 & 2.97 & 0.65 & 4.22 & 1.71 & 2.42 \\
\hline Low Intensity Residential & 0.00 & 0.04 & 0.00 & 0.04 & $*$ & $*$ & 0.03 & 0.13 & 0.02 & 0.14 & $*$ & $*$ & 0.29 & 1.43 & 0.16 & 0.83 & 0.45 & 0.64 \\
\hline Pasture/Hay & 0.09 & 0.34 & 0.15 & 0.52 & $*$ & $*$ & 1.18 & 3.26 & 1.59 & 4.32 & $*$ & $*$ & 14.51 & 25.78 & 16.50 & 30.94 & 3.74 & 5.28 \\
\hline Quarries/Gravel Pits & 0.03 & 0.28 & $*$ & $*$ & $*$ & $*$ & 0.27 & 2.49 & 0.00 & 0.09 & $*$ & $*$ & 2.15 & 21.27 & 0.11 & 2.74 & $*$ & $*$ \\
\hline
\end{tabular}




\subsection{Level 2 Assessments}

We visited 83 sites during the summer of 2011. Of these, 16 wetlands did not meet the criteria for further assessment, so 67 wetlands were sampled using the MTNHP EIA protocol. Additional sites were planned for sampling during the summer of 2012, but wildfires and related closures prohibited us from accessing any additional sites. The greatest proportion of sites sampled (41\%) was located on State Trust lands (Figure 13). Sampled wetlands represented several Ecological Systems (Table 7). Most sites sampled (45 sites) were classified as Western North American Emergent Marsh (Figure 14). Common species occurring in emergent marshes in the area were common threesquare (Schoenoplectus pungens), hardstem bulrush (Schoenoplectus acutus), common spikerush (Eleocharis palustris), and broadleaf cattail (Typha latifolia). Open water areas had floating-leaved aquatic species including water knotweed (Polygonum amphibium), broadleaf arrowhead (Sagittaria latifolia), and northern water plantain (Alisma triviale).

Wetlands associated with bermed intermittent streams were typically classified as emergent marsh. The second most commonly sampled ecological system (19 sites) was Western Great Plains Open Freshwater Depression (Figure 15). These sites were characterized by common spikerush, western wheatgrass (Pascopyrum smithii), foxtail barley (Hordeum jubatum), and American sloughgrass (Beckmannia syzigachne). We sampled two sites classified as Western Great Plains Saline Depression (Figure 16). These sites were dominated by prairie cordgrass (Spartina pectinata), foxtail barley, inland saltgrass (Distichlis spicata), and Nuttall's alkaligrass (Puccinellia nuttalliana). We sampled one site classified as Northwestern Great Plains Riparian Woodland and Shrubland (Figure 17). Plains cottonwood (Populus deltoides), western snowberry (Symphoricarpos occidentalis), Kentucky bluegrass (Poa pratensis), and foxtail barley were common at this site. Wetlands sampled were also classified by hydrogeomorphic (HGM) system in the field. The depressional HGM class was assigned most frequently (31 sites), although slope wetlands were also common (26 sites; Table 8). Hydrology of these slope wetlands was largely dominated by seeps and springs. 


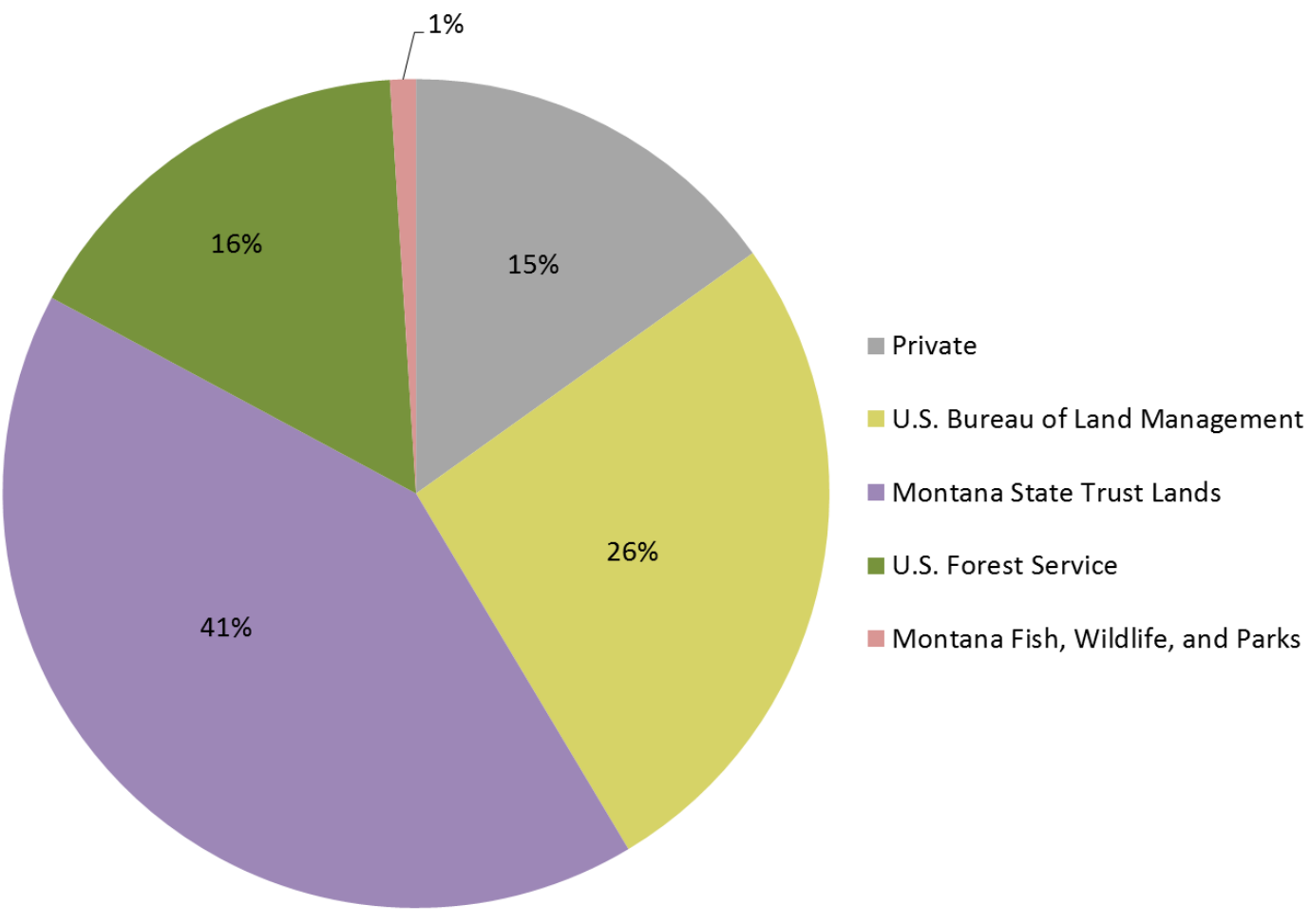

Figure 13. Sampled wetlands by land ownership in the southeast Montana basin-wide assessment project area.

Table 7. Sampled wetlands by Ecological System in the southeast Montana basin-wide assessment project area.

\begin{tabular}{lc} 
Ecological System & $\begin{array}{c}\text { Number of Sites } \\
\text { Surveyed }\end{array}$ \\
\hline Northwestern Great Plains Riparian Woodland and Shrubland & 1 \\
Western Great Plains Open Freshwater Depression Wetland & 19 \\
Western Great Plains Saline Depression Wetland & 2 \\
Western North American Emergent Marsh & 45 \\
\hline
\end{tabular}




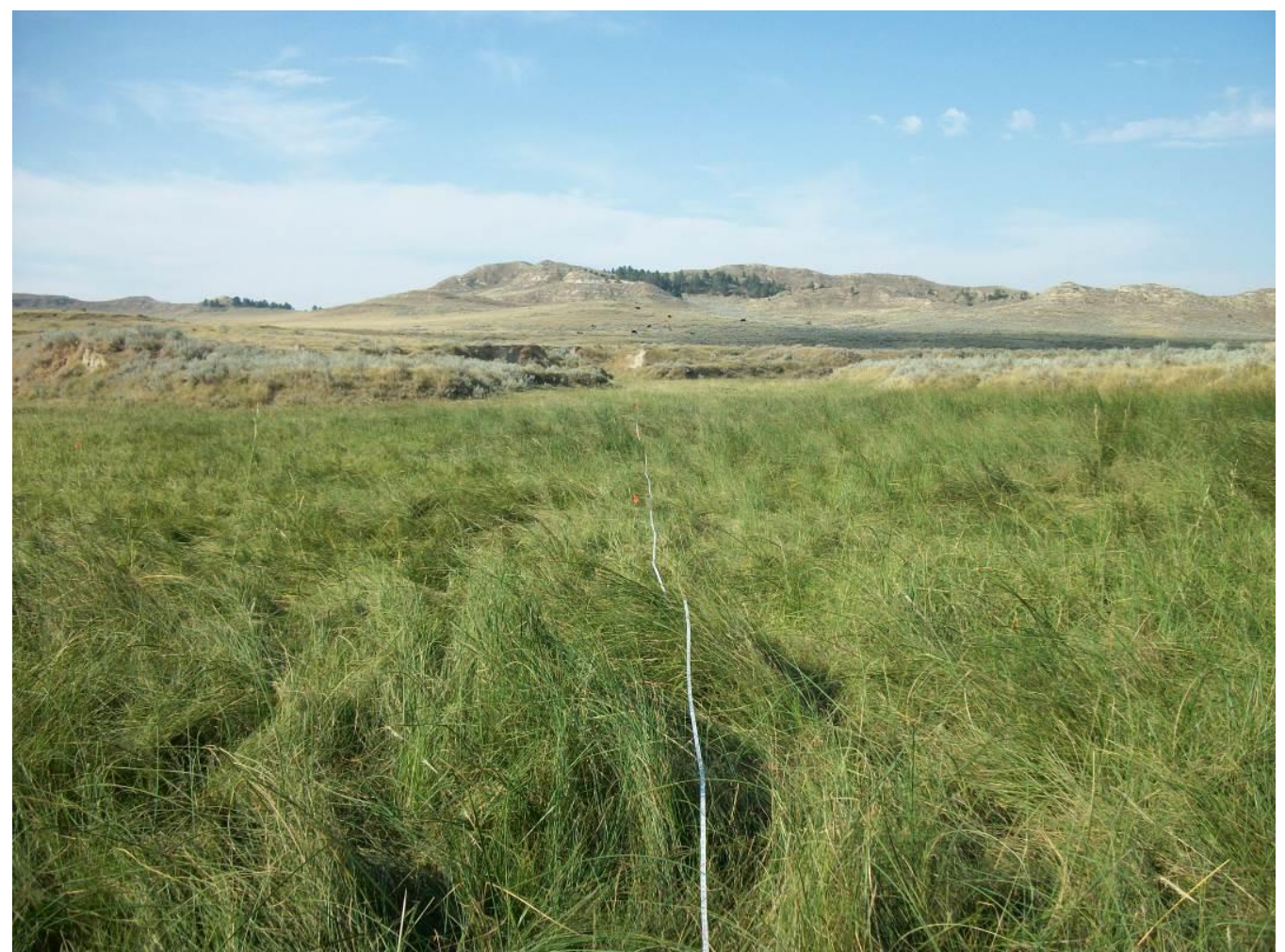

Figure 14. A Western North American Emergent Marsh sampled as part of the southeast Montana basin-wide assessment project.

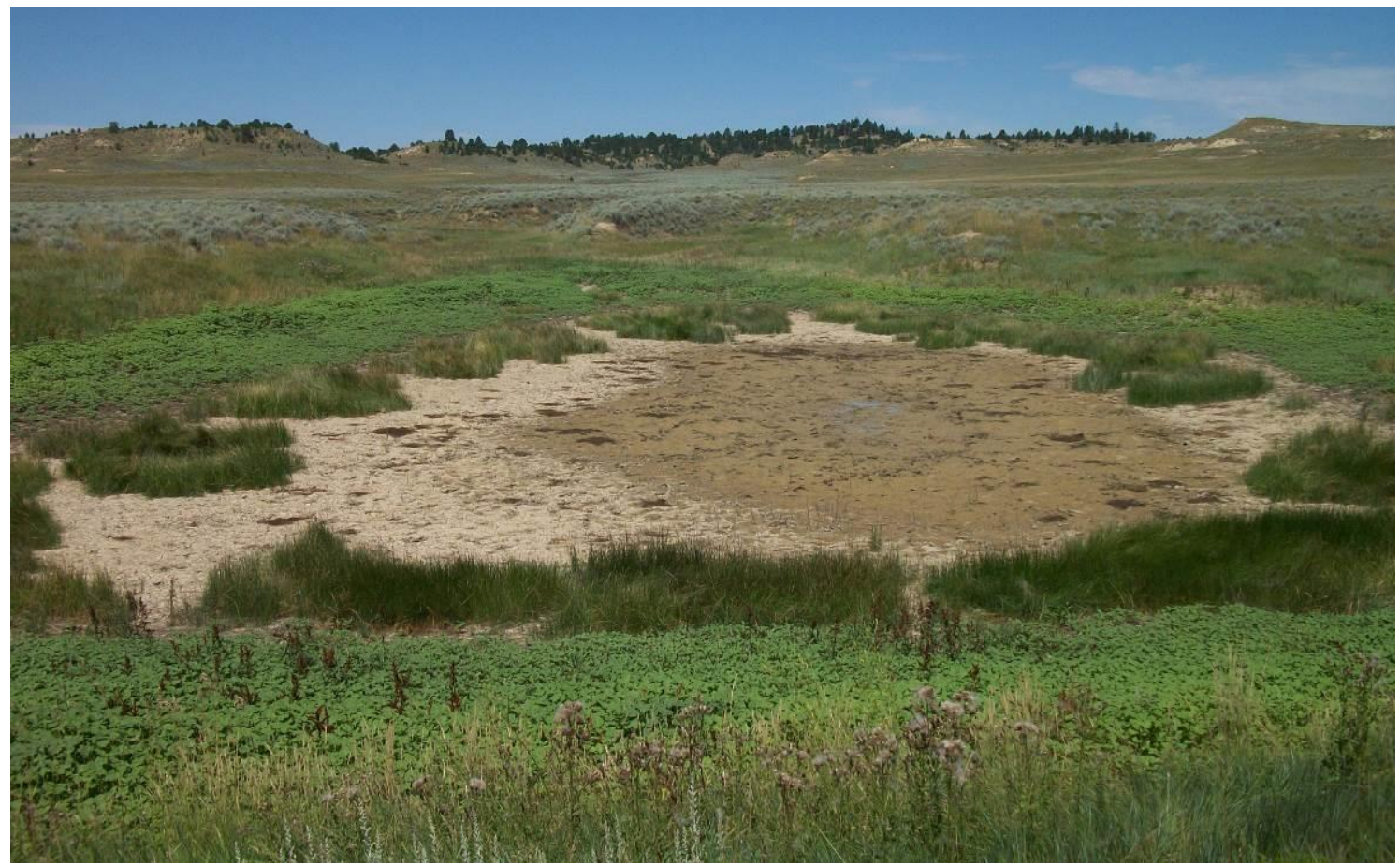

Figure 15. A Western Great Plains Open Depression Wetland sampled as part of the southeast Montana basin-wide assessment project. 


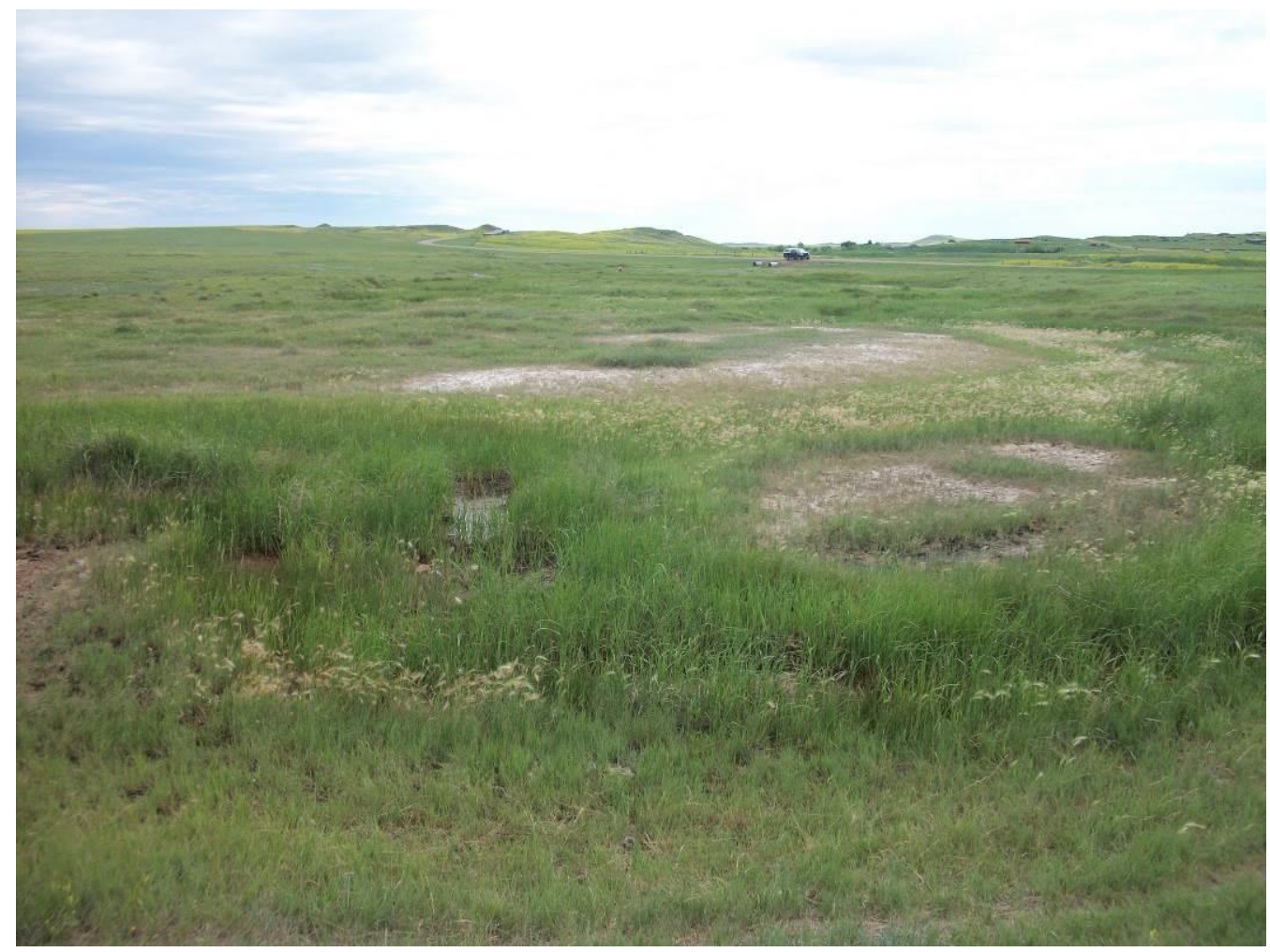

Figure 16. A Western Great Plains Saline Depression Wetland sampled as part of the southeast Montana basin-wide assessment project.

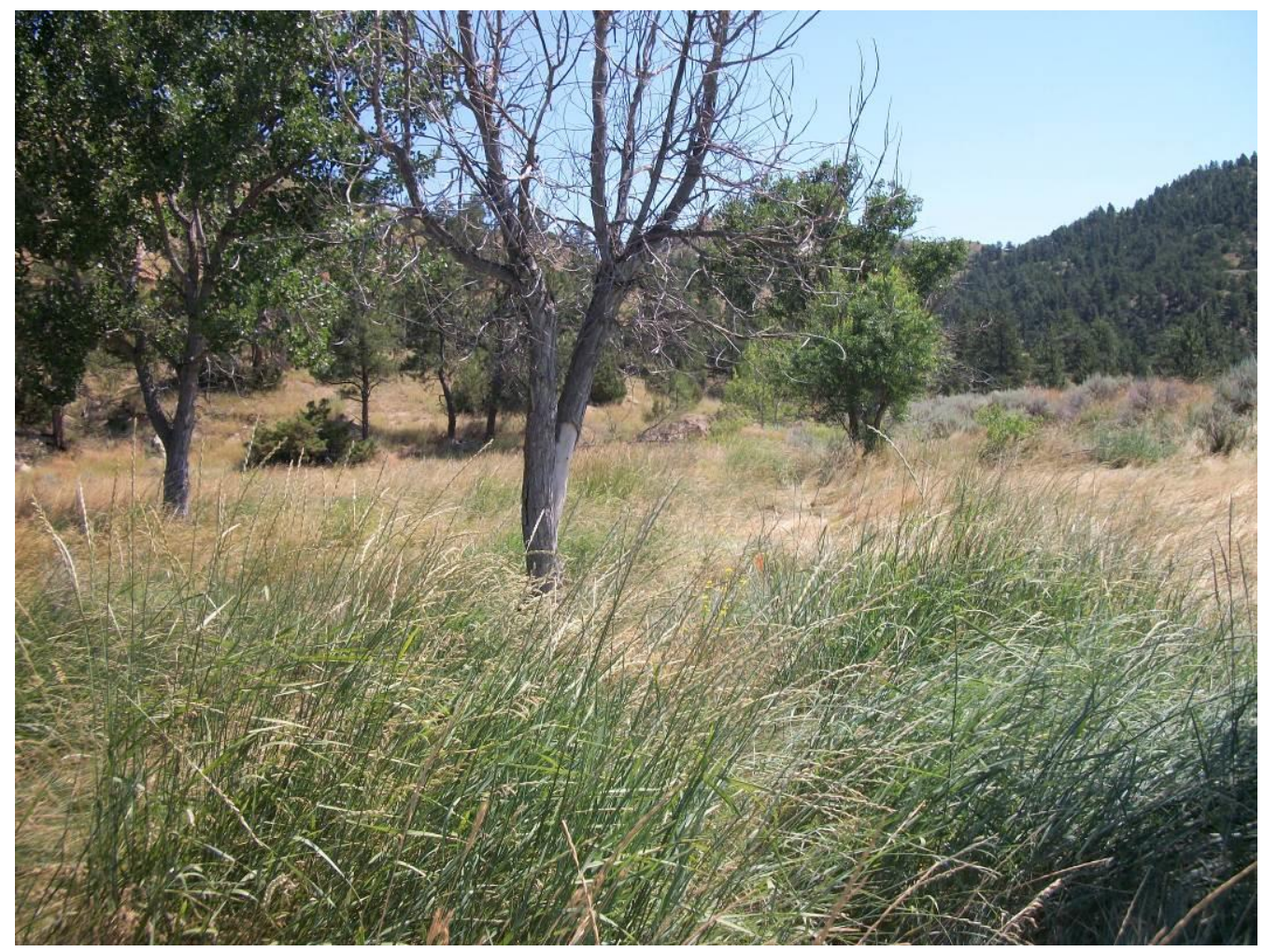

Figure 17. A Western Great Plains Riparian Woodland and Shrubland sampled as part of the southeast Montana basin-wide assessment project. 
Table 8. Sampled wetlands by hydrogeomorphic system in the southeast Montana basin-wide assessment project area.

\begin{tabular}{lc}
\hline Hydrogeomorphic System & $\begin{array}{c}\text { Number of Sites } \\
\text { Surveyed }\end{array}$ \\
\hline Depressional & 31 \\
Lacustrine Fringe & 3 \\
Riverine & 7 \\
Slope & 26 \\
\hline
\end{tabular}

Level 2 condition scores were calculated for all 67 wetlands sampled. Scores ranged from 49-93 out of a possible range of 21.5-100 (Figure 18). We divided our assessment scores into four categories defined relative to their departure from reference standard: 1) at or near expected reference standard (scores $=90-100$ ); 2 ) slight departure from expected reference standard (scores $=80-89$ ); 3) moderate departure from expected reference standard (scores $=70-79$ ); and 4) severe departure from expected reference standard (scores $<70$ ). Most sites fell into the slight to moderate departure from reference condition category (Table 9).

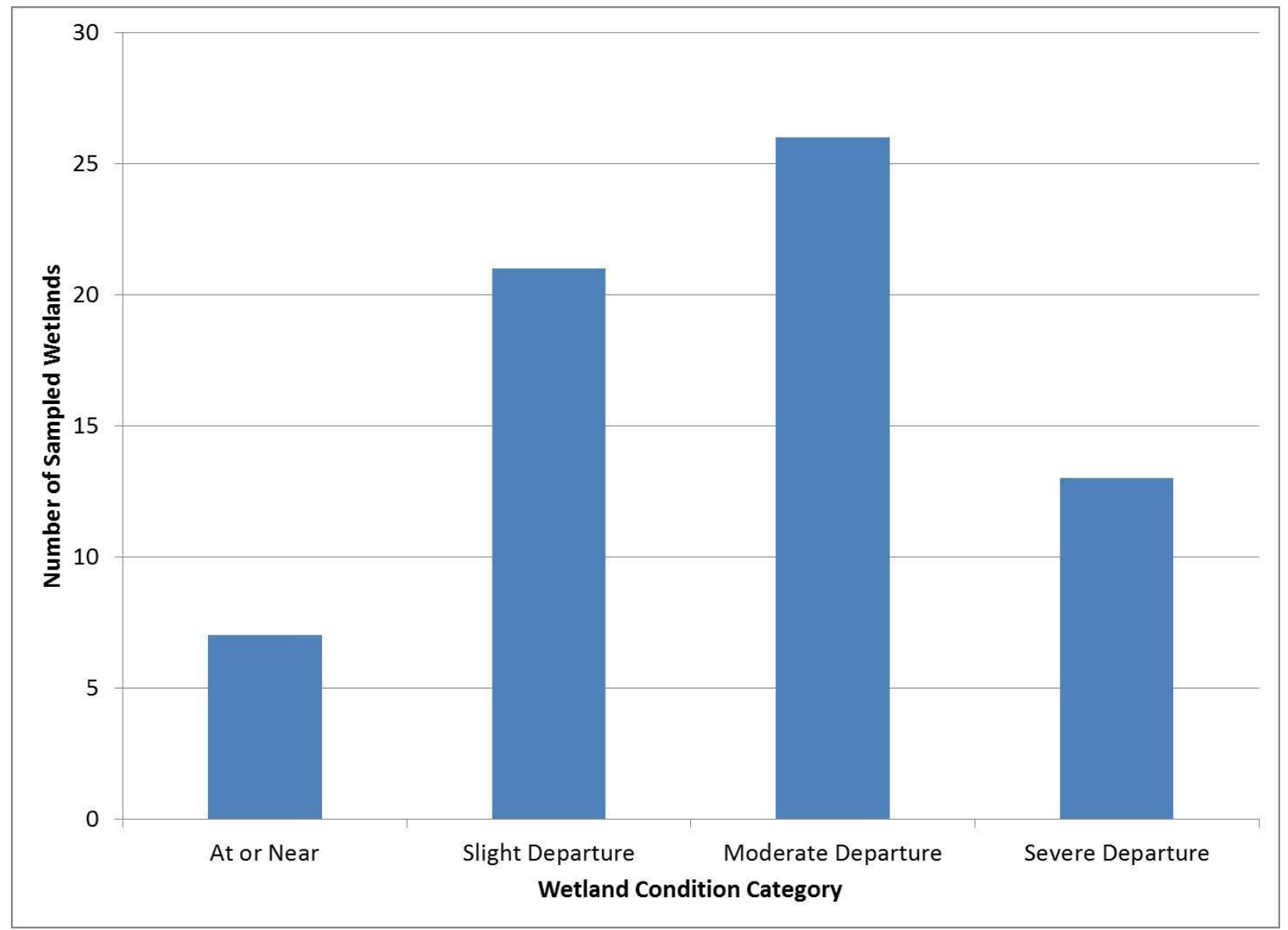

Figure 18. Level 2 assessment condition categories for wetlands assessed as part of the southeast Montana basin-wide assessment. Condition categories are relative to reference standard. 
Table 9. Wetland condition category by wetland ecological system for the southeast Montana basin-wide assessment project area. Condition categories are interpreted as: at or near reference standard; slight departure from reference standard; moderate departure from reference standard; and severe departure from reference standard.

\begin{tabular}{lcccc}
\hline \multirow{2}{*}{ Overall AA Score } & \multicolumn{4}{c}{ Condition Category } \\
& $\begin{array}{c}\text { At or Near } \\
\text { Reference }\end{array}$ & Slight & Moderate & Severe \\
\hline Northwestern Great Plains Riparian Woodland & & & & 1 \\
Western Great Plains Open Freshwater Depression Wetland & 1 & 3 & 10 & 5 \\
Western Great Plains Saline Depression Wetland & & 2 & & \\
Western North American Emergent Marsh & 6 & 16 & 16 & 7 \\
Totals & $\mathbf{7}$ & $\mathbf{2 1}$ & $\mathbf{2 6}$ & $\mathbf{1 3}$ \\
\hline
\end{tabular}

The scores for each of the four attributes comprising the overall condition score (Landscape Context, Vegetation, Physicochemical, and Hydrologic attributes) showed variable patterns (Table 10). Landscape Context and Vegetation attribute scores ranged across condition categories for open depressions and emergent marshes. Physicochemical scores were generally low for these two systems; this was largely due to the reduced soil surface integrity and poor water quality indicators (e.g., algae). Hydrologic attribute scores exhibited a severe departure from reference standard for 13 of 19 open depression sites due to hydrologic alterations as a result of impoundments and excavations. Emergent marshes showed a bimodal pattern of condition. Marshes adjacent to streams typically had high hydrologic scores (23 sites), whereas those sites adjacent to reservoirs scored lowest (19 sites). 
Table 10. Ecological Integrity Assessment (EIA) attribute condition category by wetland ecological system for the southeast Montana basin-wide assessment project area. Condition categories are interpreted as: at or near reference standard; slight departure from reference standard; moderate departure from reference standard; and severe departure from reference standard.

\begin{tabular}{|c|c|c|c|c|}
\hline & \multicolumn{4}{|c|}{ Condition Category } \\
\hline & $\begin{array}{l}\text { At or Near } \\
\text { Reference }\end{array}$ & Slight & Moderate & Severe \\
\hline \multicolumn{5}{|l|}{ Landscape Context Attribute } \\
\hline Northwestern Great Plains Riparian Woodland & & & 1 & \\
\hline Western Great Plains Open Freshwater Depression Wetland & 4 & 4 & 4 & 7 \\
\hline Western Great Plains Saline Depression Wetland & 1 & & 1 & \\
\hline Western North American Emergent Marsh & 13 & 9 & 16 & 7 \\
\hline \multicolumn{5}{|l|}{ Vegetation Attribute } \\
\hline Northwestern Great Plains Riparian Woodland & & & 1 & \\
\hline Western Great Plains Open Freshwater Depression Wetland & 2 & 8 & 6 & 3 \\
\hline Western Great Plains Saline Depression Wetland & 2 & & & \\
\hline Western North American Emergent Marsh & 13 & 17 & 13 & 2 \\
\hline \multicolumn{5}{|l|}{ Physicochemical Attribute } \\
\hline Northwestern Great Plains Riparian Woodland & & & & 1 \\
\hline Western Great Plains Open Freshwater Depression Wetland & 3 & 1 & 4 & 11 \\
\hline Western Great Plains Saline Depression Wetland & & 1 & & 1 \\
\hline Western North American Emergent Marsh & 4 & 13 & 14 & 14 \\
\hline \multicolumn{5}{|l|}{ Hydrologic Attribute } \\
\hline Northwestern Great Plains Riparian Woodland & & & & 1 \\
\hline Western Great Plains Open Freshwater Depression Wetland & 3 & 3 & & 13 \\
\hline Western Great Plains Saline Depression Wetland & & 1 & 1 & \\
\hline Western North American Emergent Marsh & 23 & 2 & 1 & 19 \\
\hline
\end{tabular}


Table 11. Stressors observed in the assessment area (AA) and the 200-m envelope around the AA and the corresponding number of sampled wetland sites, categorized by Ecological Integrity Assessment (EIA) attribute. Note that some stressors are considered to impact more than one attribute.

\begin{tabular}{lcc}
\hline & Number of Sites \\
\cline { 2 - 3 } Landscape Context & AA & $\mathbf{2 0 0}$ \\
\hline Paved surfaces & - & 1 \\
Unpaved roads & 26 & 42 \\
Recreation or human visitation & 4 & 6 \\
Filling or dumping of sediment or fill & 1 & 1 \\
Trash or refuse dumping & 1 & 3 \\
Dryland farming & 2 & 3 \\
Livestock grazing & 46 & 48 \\
Haying of native grassland & 2 & 4 \\
Plowing or discing & 1 & 2 \\
Resource extraction & 1 & 2 \\
Beetle-killed Pinus species & 1 & 1 \\
\hline Vegetation & & \\
\hline Vegetation conversion & -- & 1 \\
Livestock grazing & 46 & 48 \\
Haying of native grassland & 2 & 4 \\
Browsing of woody vegetation by native ungulates & 3 & 3 \\
\hline Physicochemical & & \\
\hline Trash or refuse dumping & 1 & 3 \\
Plowing or discing & 1 & 2 \\
\hline Hydrologic & & \\
\hline Upstream spring box & 1 & 1 \\
Impoundment of flowing water & 32 & 38 \\
Potential for agricultural runoff & 3 & 3 \\
Reservoir/stock pond & 1 & 26 \\
Pumps, diversions, or ditches that move water into wetland & 33 & 37 \\
Pumps, diversions, or ditches that move water out of wetland & 1 \\
Berms/Dikes/Levees & & \\
\hline & & 3 \\
\hline
\end{tabular}

\subsection{Stressors}

The scope and severity of each observed stressor were recorded both within the AA and within a 200-m envelope around the AA to help identify potential impacts to wetland condition. Fewer stressors were recorded in the AA than in the 200-m envelope around the AA (Table 11). This is partially attributable to the requirement that at least $90 \%$ of the AA be placed within a wetland, so stressors like paved roads cannot be included in an AA. Only 17 sites had no observed stressors in the AA (Table 12), and 15 sites had no observed stressors within the 200-m envelope (Table 13). Stressor impact ratings spanned No Impact to Medium Impact at both scales. When 
examined by attribute, sites occurred across a broader range of impact categories within the AA and within the 200-m envelope (Tables 14 and Table 15).

Livestock grazing and unpaved roads were the most common stressors potentially impacting Landscape Context and Vegetation for both the AA and the 200-m envelope. Hydrologic stressors were observed at $48 \%$ of AAs and $57 \%$ of $200-\mathrm{m}$ envelopes, due largely to impoundments and berms creating reservoirs or stock ponds. Sites had few observed Physicochemical stressors.

Table 12. Count of overall assessment area (AA) stressor impact ratings by wetland ecological system for the southeast Montana basin-wide assessment project area.

\begin{tabular}{|c|c|c|c|c|c|c|}
\hline & \multicolumn{5}{|c|}{ Impact Rating } & \multirow[b]{2}{*}{$\begin{array}{l}\text { Number } \\
\text { of Sites }\end{array}$} \\
\hline & $\begin{array}{l}\text { No } \\
\text { Impact }\end{array}$ & $\begin{array}{l}\text { Low } \\
\text { Impact }\end{array}$ & $\begin{array}{l}\text { Medium } \\
\text { Impact }\end{array}$ & $\begin{array}{l}\text { High } \\
\text { Impact }\end{array}$ & $\begin{array}{c}\text { Very } \\
\text { High } \\
\text { Impact }\end{array}$ & \\
\hline Northwestern Great Plains Riparian & & 1 & & & & 1 \\
\hline $\begin{array}{l}\text { Western Great Plains Open Freshwater } \\
\text { Depression Wetland }\end{array}$ & 5 & 9 & 5 & & & 19 \\
\hline $\begin{array}{l}\text { Western Great Plains Saline Depression } \\
\text { Wetland }\end{array}$ & & 1 & 1 & & & 2 \\
\hline Western North American Emergent Marsh & 12 & 25 & 8 & & & 45 \\
\hline
\end{tabular}

Table 13. Overall stressor impact rating within the 200-m envelope around the assessment (AA) by wetland ecological system for the southeast Montana basin-wide assessment project area.

\begin{tabular}{|c|c|c|c|c|c|}
\hline & \multicolumn{5}{|c|}{ Impact Rating } \\
\hline & $\begin{array}{c}\text { No } \\
\text { Impact }\end{array}$ & $\begin{array}{c}\text { Low } \\
\text { Impact }\end{array}$ & $\begin{array}{c}\text { Medium } \\
\text { Impact }\end{array}$ & $\begin{array}{l}\text { High } \\
\text { Impact }\end{array}$ & $\begin{array}{l}\text { Very } \\
\text { High } \\
\text { Impact }\end{array}$ \\
\hline Northwestern Great Plains Riparian & & 1 & & & \\
\hline $\begin{array}{l}\text { Western Great Plains Open Freshwater } \\
\text { Depression Wetland } \\
\text { Western Great Plains Saline Depression }\end{array}$ & 5 & 12 & 2 & & \\
\hline Wetland & & 1 & 1 & & \\
\hline Western North American Emergent Marsh & 10 & 32 & 3 & & \\
\hline
\end{tabular}


Table 14. Ecological Integrity Assessment (EIA) attribute stressor impact rating within the assessment area (AA) by wetland ecological system for the southeast Montana basin-wide assessment project area.

\begin{tabular}{|c|c|c|c|c|c|}
\hline & \multicolumn{5}{|c|}{ Impact Rating } \\
\hline & $\begin{array}{c}\text { No } \\
\text { Impact }\end{array}$ & $\begin{array}{l}\text { Low } \\
\text { Impact }\end{array}$ & $\begin{array}{l}\text { Medium } \\
\text { Impact }\end{array}$ & $\begin{array}{l}\text { High } \\
\text { Impact }\end{array}$ & $\begin{array}{l}\text { Very } \\
\text { High } \\
\text { Impact }\end{array}$ \\
\hline \multicolumn{6}{|l|}{ Landscape Context } \\
\hline Northwestern Great Plains Riparian & & 1 & & & \\
\hline $\begin{array}{l}\text { Western Great Plains Open Freshwater } \\
\text { Depression Wetland } \\
\text { Western Great Plains Saline Depression }\end{array}$ & 1 & 9 & 4 & 5 & \\
\hline Wetland & & 1 & & 1 & \\
\hline Western North American Emergent Marsh & 2 & 23 & 14 & 6 & \\
\hline \multicolumn{6}{|l|}{ Vegetation } \\
\hline $\begin{array}{l}\text { Northwestern Great Plains Riparian } \\
\text { Western Great Plains Open Freshwater }\end{array}$ & 1 & & & & \\
\hline $\begin{array}{l}\text { Depression Wetland } \\
\text { Western Great Plains Saline Depression }\end{array}$ & 6 & 4 & 4 & 5 & \\
\hline Wetland & & 1 & & 1 & \\
\hline Western North American Emergent Marsh & 10 & 17 & 12 & 6 & \\
\hline \multicolumn{6}{|l|}{ Physicochemical } \\
\hline $\begin{array}{l}\text { Northwestern Great Plains Riparian } \\
\text { Western Great Plains Open Freshwater }\end{array}$ & & 1 & & & \\
\hline $\begin{array}{l}\text { Depression Wetland } \\
\text { Western Great Plains Saline Depression }\end{array}$ & 18 & 1 & & & \\
\hline Wetland & 1 & 1 & & & \\
\hline Western North American Emergent Marsh & 40 & 3 & 2 & & \\
\hline \multicolumn{6}{|l|}{ Hydrologic } \\
\hline $\begin{array}{l}\text { Northwestern Great Plains Riparian } \\
\text { Western Great Plains Open Freshwater }\end{array}$ & & 1 & & & \\
\hline $\begin{array}{l}\text { Depression Wetland } \\
\text { Western Great Plains Saline Depression }\end{array}$ & 3 & 10 & 5 & 1 & \\
\hline Wetland & & 2 & & & \\
\hline Western North American Emergent Marsh & 17 & 21 & 5 & 1 & 1 \\
\hline
\end{tabular}


Table 15. Ecological Integrity Assessment (EIA) attribute stressor impact rating within the 200$m$ envelope around the assessment area (AA) by wetland ecological system for the southeast Montana basin-wide assessment project area.

\begin{tabular}{|c|c|c|c|c|c|}
\hline & \multicolumn{5}{|c|}{ Impact Rating } \\
\hline & $\begin{array}{c}\text { No } \\
\text { Impact }\end{array}$ & $\begin{array}{l}\text { Low } \\
\text { Impact }\end{array}$ & $\begin{array}{c}\text { Medium } \\
\text { Impact }\end{array}$ & $\begin{array}{c}\text { High } \\
\text { Impact }\end{array}$ & $\begin{array}{l}\text { Very } \\
\text { High } \\
\text { Impact }\end{array}$ \\
\hline \multicolumn{6}{|l|}{ Landscape Context } \\
\hline Northwestern Great Plains Riparian & & 1 & & & \\
\hline Western Great Plains Open Freshwater & & & & & \\
\hline Depression Wetland & 1 & 9 & 4 & 5 & \\
\hline Western Great Plains Saline Depression & & & & & \\
\hline Wetland & & 1 & & 1 & \\
\hline Western North American Emergent Marsh & 2 & 23 & 14 & 6 & \\
\hline \multicolumn{6}{|l|}{ Vegetation } \\
\hline $\begin{array}{l}\text { Northwestern Great Plains Riparian } \\
\text { Western Great Plains Open Freshwater }\end{array}$ & 1 & & & & \\
\hline Depression Wetland & 6 & 4 & 4 & 5 & \\
\hline Western Great Plains Saline Depression & & & & & \\
\hline Wetland & & 1 & & 1 & \\
\hline Western North American Emergent Marsh & 10 & 17 & 12 & 6 & \\
\hline \multicolumn{6}{|l|}{ Physicochemical } \\
\hline Northwestern Great Plains Riparian & & 1 & & & \\
\hline Western Great Plains Open Freshwater & & & & & \\
\hline Depression Wetland & 18 & 1 & & & \\
\hline Western Great Plains Saline Depression & & & & & \\
\hline Wetland & 1 & 1 & & & \\
\hline Western North American Emergent Marsh & 40 & 3 & 2 & & \\
\hline \multicolumn{6}{|l|}{ Hydrologic } \\
\hline Northwestern Great Plains Riparian & & 1 & & & \\
\hline $\begin{array}{l}\text { Western Great Plains Open Freshwater } \\
\text { Depression Wetland } \\
\text { Western Great Plains Saline Depression }\end{array}$ & 3 & 10 & 5 & 1 & \\
\hline Wetland & & 2 & & & \\
\hline Western North American Emergent Marsh & 17 & 21 & 5 & 1 & 1 \\
\hline
\end{tabular}

\subsection{Level 3 Assessments}

We completed 19 Level 3 intensive assessments within the project area, encountering 161 plant taxa. Of these, 140 taxa were identified to the species level. Of the 161 total plant taxa encountered, 71 species were encountered at only one site and 25 species were encountered at only two sites. The average number of species encountered per site was 18 (range 1-45). Of the 140 taxa identified to species, 111 (79\%) were native species and 29 were exotic species. 
The most commonly encountered plant species was foxtail barley (Hordeum jubatum; Table 16). This species is a facultative wetland species that inhabits a variety of wetland systems in the Great Plains.

Table 16. Five most commonly encountered plant species during Level 3 intensive assessments in the southeast Montana basin-wide assessment project area.

\begin{tabular}{|c|c|c|c|c|c|}
\hline Scientific Name & Common name & $\begin{array}{l}\text { Number of } \\
\text { Sites } \\
\text { Encountered }\end{array}$ & C-Value & $\begin{array}{l}\text { Wetland } \\
\text { Indicator } \\
\text { Status }\end{array}$ & Native Status \\
\hline Hordeum jubatum & foxtail barley & 17 & 2 & FACW & Native \\
\hline Poa pratensis & Kentucky bluegrass & 15 & 0 & FACU & Exotic \\
\hline Eleocharis palustris & common spikerush & 12 & 4 & OBL & Native \\
\hline Elymus smithii & western wheatgrass & 12 & 3 & FACU & Native \\
\hline Carex praegracilis & clustered field sedge & 10 & 4 & FACW & Native \\
\hline
\end{tabular}

\subsection{Floristic Quality Assessment}

We calculated floristic quality assessment (FQA) metrics for all 19 Level 3 assessment sites (Table 17). These metrics can be used as a measure of biotic condition. Mean $\mathrm{C}$-value across these sites was 3.18 (range 1.55 - 6.00). Most C-values for native species encountered fell between 3 and 5, indicating most species observed had some degree of habitat specificity but had a moderate tolerance to disturbance (Figure 19). 
Table 17. Means and standard deviations of all floristic quality assessment (FQA) metrics considered by Ecological System for Level 3 assessments completed in the southeast Montana basin-wide assessment project area.

\begin{tabular}{|c|c|c|c|c|c|c|c|c|}
\hline & \multicolumn{2}{|c|}{$\begin{array}{c}\text { Northwestern Great } \\
\text { Plains Riparian } \\
\text { Woodland and Shrubland } \\
\quad(n=1)\end{array}$} & \multicolumn{2}{|c|}{$\begin{array}{c}\text { Western Great Plains } \\
\text { Open Freshwater } \\
\text { Depression Wetland } \\
(n=5)\end{array}$} & \multicolumn{2}{|c|}{$\begin{array}{c}\text { Western Great Plains } \\
\text { Saline Depression } \\
\text { Wetland }(\mathrm{n}=1)\end{array}$} & \multicolumn{2}{|c|}{$\begin{array}{l}\text { Western North } \\
\text { American Emergent } \\
\text { Marsh }(\mathrm{n}=12)\end{array}$} \\
\hline & Mean & $\mathrm{SD}$ & Mean & SD & Mean & $\mathrm{SD}$ & Mean & $\mathrm{SD}$ \\
\hline Total species richness & 20.00 & $*$ & 8.60 & 6.54 & 15.00 & $*$ & 21.75 & 10.15 \\
\hline Native species richness & 9.00 & $*$ & 5.40 & 5.13 & 12.00 & $*$ & 16.17 & 7.07 \\
\hline Non-native species richness & 11.00 & $*$ & 3.75 & 0.50 & 2.00 & $*$ & 5.81 & 3.52 \\
\hline Cover of native graminoids & 3.97 & $*$ & 6.74 & 5.03 & 6.81 & $*$ & 5.68 & 1.88 \\
\hline Mean C-value of all species & 1.55 & $*$ & 3.04 & 1.75 & 3.80 & $*$ & 3.26 & 0.81 \\
\hline Mean C-value of native species & 3.44 & $*$ & 4.46 & 1.05 & 4.38 & $*$ & 4.15 & 0.50 \\
\hline $\begin{array}{l}\text { Cover-weighted Mean C-value of all } \\
\text { species }\end{array}$ & 1.40 & $*$ & 3.01 & 1.73 & 4.40 & $*$ & 3.91 & 1.34 \\
\hline $\begin{array}{l}\text { Cover-weighted Mean C-value of } \\
\text { native species }\end{array}$ & 3.74 & $*$ & 4.74 & 1.36 & 4.45 & * & 4.43 & 0.83 \\
\hline FQI of all species & 6.93 & $*$ & 7.16 & 2.90 & 14.72 & $*$ & 14.40 & 3.68 \\
\hline FQI of native species & 10.33 & $*$ & 8.85 & 2.92 & 15.19 & $*$ & 16.29 & 4.07 \\
\hline Cover-weighted FQI of all species & 6.25 & $*$ & 7.02 & 2.45 & 17.06 & $*$ & 17.14 & 5.62 \\
\hline Cover-weighted FQI of native species & 11.21 & $*$ & 9.45 & 3.39 & 16.04 & $*$ & 17.40 & 4.27 \\
\hline Adjusted FQI of native species & 23.11 & $*$ & 36.21 & 14.25 & 39.22 & $*$ & 36.49 & 6.58 \\
\hline $\begin{array}{l}\text { Adjusted cover-weighted FQI of } \\
\text { native species }\end{array}$ & 25.08 & $*$ & 37.92 & 13.86 & 39.80 & $*$ & 39.18 & 9.39 \\
\hline Average Wetness Index & 0.20 & $*$ & -1.08 & 0.66 & -1.25 & $*$ & -0.29 & 0.76 \\
\hline Percent of Total Species FAC or OBL & 10.00 & $*$ & 54.87 & 27.06 & 80.00 & $*$ & 44.16 & 25.16 \\
\hline
\end{tabular}




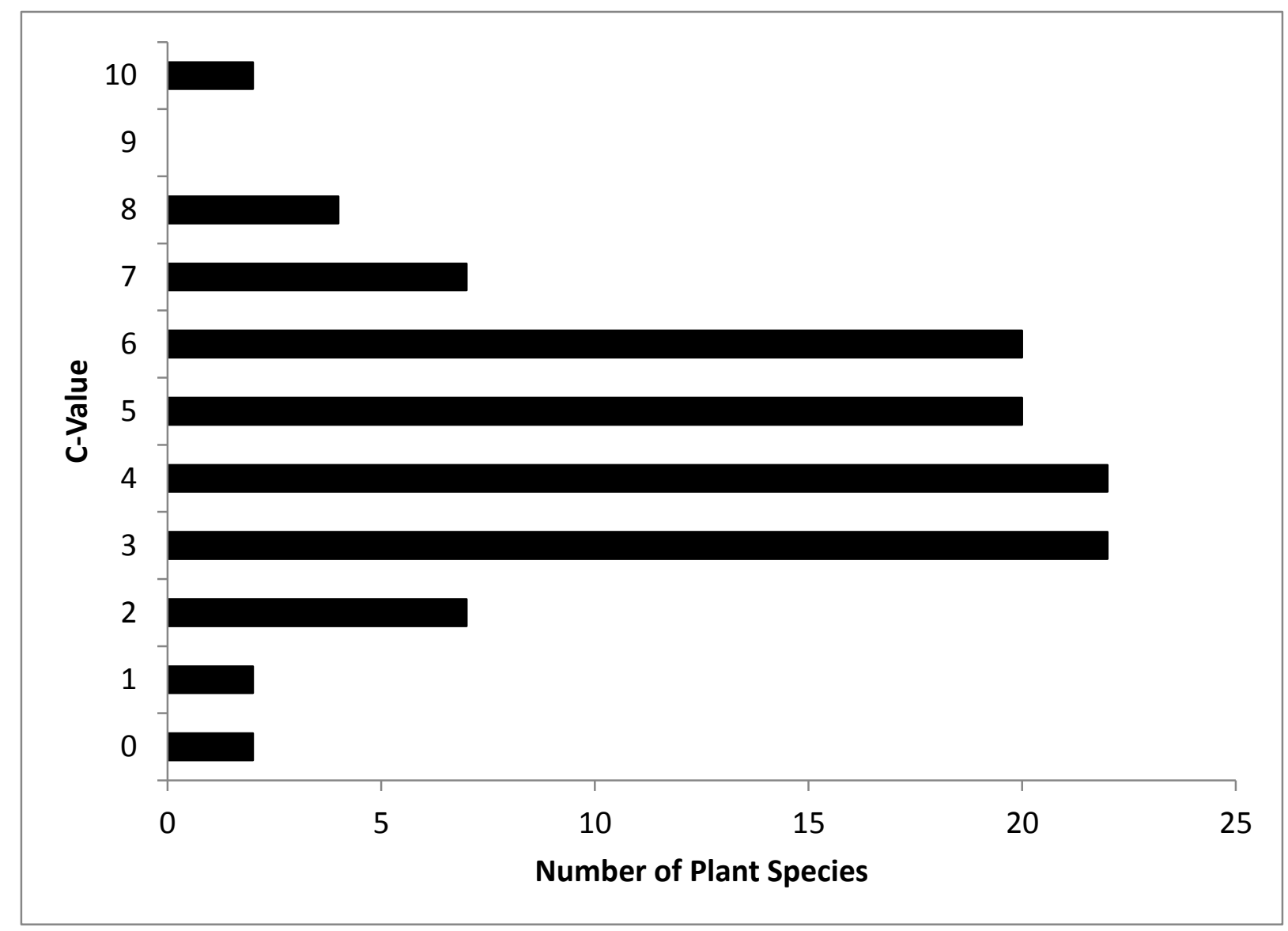

Figure 19. Frequency distribution of $C$-values of plant species encountered during Level 3 assessments in the southeast Montana basin-wide assessment project.

\subsection{Comparisons of Level 2 \& 3 Results}

To understand the effectiveness of this assessment framework in determining the condition of wetlands in the southeast Montana project area, we compared Level 3 assessment results with Level 2 assessment results.

Impact ratings within the 200-m envelope around the AA and within the AA showed moderate negative correlations with overall Level 2 assessment scores $(r=-0.49$ and $r=-0.58$, respectively; Tables 18 and 19). However, only the Hydrologic attribute score showed more than a weak correlation with overall impact rating. 
Table 18. Spearman's correlation coefficients of Impact Category scores calculated within a 200-m envelope of the assessment area with Level 2 assessment attribute and overall scores.

\begin{tabular}{lrrrrr}
\hline & \multicolumn{5}{c}{ Level 2 Assessment Scores } \\
\cline { 2 - 6 } Impact Category & $\begin{array}{c}\text { Landscape } \\
\text { Context }\end{array}$ & \multicolumn{1}{c}{ Vegetation } & Physicochemical & Hydrologic & $\begin{array}{c}\text { Overall } \\
\text { Condition }\end{array}$ \\
\hline Landscape Context & -0.14 & -0.17 & -0.31 & -0.01 & -0.22 \\
Vegetation & 0.00 & 0.00 & -0.28 & 0.10 & -0.08 \\
Physicochemical & -0.13 & 0.12 & -0.08 & 0.02 & -0.05 \\
Hydrologic & -0.20 & -0.04 & 0.00 & -0.66 & -0.45 \\
Overall Impact Rating & -0.32 & -0.14 & -0.27 & -0.42 & -0.49 \\
\hline
\end{tabular}

Table 19. Spearman's correlation coefficients of Impact Category scores calculated within the assessment area (AA) with Level 2 assessment attribute and overall scores.

\begin{tabular}{lrrrrr}
\hline & \multicolumn{6}{c}{ Level 2 Assessment Scores } \\
\cline { 2 - 6 } Impact Category & $\begin{array}{c}\text { Landscape } \\
\text { Context }\end{array}$ & \multicolumn{1}{c}{ Vegetation } & Physicochemical & Hydrologic & $\begin{array}{c}\text { Overall } \\
\text { Condition }\end{array}$ \\
\hline Landscape Context & -0.09 & -0.19 & -0.28 & 0.05 & -0.17 \\
Vegetation & 0.01 & -0.11 & -0.32 & 0.06 & -0.13 \\
Physicochemical & -0.05 & -0.06 & -0.19 & -0.07 & -0.14 \\
Hydrologic & -0.28 & 0.00 & -0.06 & -0.71 & -0.55 \\
Overall Impact Rating & -0.30 & -0.15 & -0.25 & -0.57 & -0.58 \\
\hline
\end{tabular}

We evaluated 16 vegetation metrics in the FQA. Several of these metrics were highly correlated $(r \geq 0.9)$ with each other (Table 20). Of the 16 vegetation metrics evaluated in the FQA, only three were correlated with either stressors or overall wetland condition (Table 21). 
Table 20. Spearman's correlation coefficients of metrics included in the floristic quality assessment (FQA). Correlation coefficients of 0.90 or greater are in bold.

\begin{tabular}{|c|c|c|c|c|c|c|c|c|c|c|c|c|c|c|c|c|}
\hline & $\begin{array}{c}\text { Total } \\
\text { species } \\
\text { richness }\end{array}$ & $\begin{array}{c}\text { Native } \\
\text { species } \\
\text { richness }\end{array}$ & $\begin{array}{c}\text { Non- } \\
\text { native } \\
\text { species } \\
\text { richness }\end{array}$ & $\begin{array}{c}\text { Cover of } \\
\text { native } \\
\text { graminoids }\end{array}$ & $\begin{array}{c}\text { Mean C- } \\
\text { value of all } \\
\text { species }\end{array}$ & $\begin{array}{c}\text { Mean C- } \\
\text { value of } \\
\text { native species }\end{array}$ & $\begin{array}{c}\text { Cover- } \\
\text { weighted } \\
\text { Mean C- } \\
\text { value of all } \\
\text { species } \\
\end{array}$ & $\begin{array}{c}\text { Cover-weighted } \\
\text { Mean C-value } \\
\text { of native species }\end{array}$ & $\begin{array}{c}\begin{array}{c}\text { FQI of } \\
\text { all } \\
\text { species }\end{array} \\
\end{array}$ & $\begin{array}{c}\text { FQI of } \\
\text { native } \\
\text { species }\end{array}$ & $\begin{array}{c}\text { Cover- } \\
\text { weighted } \\
\text { FQI of all } \\
\text { species }\end{array}$ & $\begin{array}{c}\text { Cover- } \\
\text { weighted } \\
\text { FQI of native } \\
\text { species } \\
\end{array}$ & $\begin{array}{c}\text { Adjusted } \\
\text { FQI }\end{array}$ & $\begin{array}{l}\text { Adjusted cover- } \\
\text { weighted FQI }\end{array}$ & $\begin{array}{l}\text { - Wetness } \\
\text { Index }\end{array}$ & $\begin{array}{c}\text { Percent of } \\
\text { Total } \\
\text { Species } \\
\text { FAC or } \\
\text { OBL } \\
\end{array}$ \\
\hline Total species richness & 1.00 & & & & & & & & & & & & & & & \\
\hline Native species richness & 0.95 & 1.00 & & & & & & & & & & & & & & \\
\hline Non-native species richness & 0.78 & 0.61 & 1.00 & & & & & & & & & & & & & \\
\hline Cover of native graminoids & -0.08 & 0.00 & -0.23 & 1.00 & & & & & & & & & & & & \\
\hline Mean C-value of all species & -0.14 & 0.06 & -0.63 & -0.07 & 1.00 & & & & & & & & & & & \\
\hline Mean C-value of native species & -0.32 & -0.24 & -0.44 & -0.46 & 0.67 & 1.00 & & & & & & & & & & \\
\hline $\begin{array}{l}\text { Cover-weighted Mean C-value of all } \\
\text { species }\end{array}$ & -0.21 & -0.01 & -0.59 & -0.04 & 0.67 & 0.32 & 1.00 & & & & & & & & & \\
\hline $\begin{array}{l}\text { Cover-weighted Mean C-value of } \\
\text { native species }\end{array}$ & -0.37 & -0.24 & -0.50 & -0.47 & 0.50 & 0.61 & 0.69 & 1.00 & & & & & & & & \\
\hline FQI of all species & 0.66 & 0.81 & 0.16 & 0.03 & 0.54 & 0.23 & 0.30 & 0.10 & 1.00 & & & & & & & \\
\hline FQI of native species & 0.82 & 0.92 & 0.42 & 0.00 & 0.29 & 0.06 & 0.11 & -0.05 & 0.94 & 1.00 & & & & & & \\
\hline Cover-weighted FQI of all species & 0.60 & 0.75 & 0.18 & 0.05 & 0.27 & -0.13 & 0.52 & 0.17 & 0.76 & 0.76 & 1.00 & & & & & \\
\hline Cover-weighted FQI of native species & 0.74 & 0.86 & 0.36 & -0.12 & 0.23 & -0.03 & 0.30 & 0.19 & 0.86 & 0.89 & 0.90 & 1.00 & & & & \\
\hline Adjusted FQI & -0.13 & 0.02 & -0.51 & -0.27 & 0.92 & 0.85 & 0.56 & 0.52 & 0.51 & 0.27 & 0.18 & 0.19 & 1.00 & & & \\
\hline Adjusted cover-weighted FQI & -0.37 & -0.20 & -0.59 & -0.33 & 0.60 & 0.55 & 0.82 & 0.96 & 0.16 & -0.02 & 0.27 & 0.22 & 0.57 & 1.00 & & \\
\hline Wetness Index & 0.71 & 0.55 & 0.85 & -0.20 & -0.57 & -0.46 & -0.40 & -0.26 & 0.13 & 0.36 & 0.24 & 0.40 & -0.50 & -0.31 & 1.00 & \\
\hline Percent of Total Species FAC or OBL & -0.51 & -0.30 & -0.88 & 0.19 & 0.82 & 0.53 & 0.60 & 0.36 & 0.18 & -0.10 & 0.01 & -0.14 & 0.72 & 0.47 & -0.90 & 1.00 \\
\hline
\end{tabular}


Table 21. Vegetation metrics included in the floristic quality assessment (FQA), and their response to stressors within the assessment area (AA), within the 200-m envelope surrounding the $A A$, and their relationship with overall wetland condition scores. Response categories are defined as follows: poor correlation refers to metrics with weak correlation $(r<0.3)$ with stressors at either scale and/or overall condition scores. Correlated indicates metrics that show a response ( $r \geq 0.3)$ to either stressors and/or overall wetland condition scores. FQA metrics that were highly correlated ( $r \geq 0.9)$ with other FQA metrics were not considered.

\begin{tabular}{|c|c|c|c|c|}
\hline Metric & Response & $\begin{array}{l}\text { Response } \\
\text { to } \\
\text { stressors } \\
\text { (AA) }\end{array}$ & $\begin{array}{c}\text { Response } \\
\text { to } \\
\text { stressors } \\
(200 \mathrm{~m}) \\
\end{array}$ & $\begin{array}{c}\text { Overall } \\
\text { Condition } \\
\text { Score }\end{array}$ \\
\hline Non-native species richness & poor correlation & -0.20 & -0.12 & 0.01 \\
\hline Cover of native graminoids & correlated & -0.09 & -0.07 & 0.42 \\
\hline Mean C-value of native species & poor correlation & 0.13 & 0.00 & -0.18 \\
\hline $\begin{array}{l}\text { Cover-weighted Mean C-value of all } \\
\text { species }\end{array}$ & poor correlation & -0.20 & -0.17 & 0.18 \\
\hline $\begin{array}{l}\text { Cover-weighted Mean C-value of } \\
\text { native species }\end{array}$ & poor correlation & -0.14 & 0.01 & -0.15 \\
\hline FQI of native species & correlated & -0.42 & -0.19 & 0.47 \\
\hline Cover-weighted FQI of native species & correlated & -0.49 & -0.12 & 0.31 \\
\hline Wetness Index & poor correlation & -0.24 & -0.25 & 0.05 \\
\hline
\end{tabular}

Although some FQA metrics showed poor correlation with overall condition scores, they did show some weak to moderate correlations with individual Level 2 attribute scores (Table 22). Non-native species richness showed a negative correlation with the Vegetation attribute score.

Table 22. Spearman's correlation coefficients of floristic quality assessment (FQA) metrics with Level 2 assessment attribute scores. FQA metrics that were highly correlated $(r \geq 0.9)$ with other FQA metrics were not considered.

\begin{tabular}{lrrrr}
\hline & $\begin{array}{c}\text { Landscape } \\
\text { Context }\end{array}$ & Vegetation & Physicochemical & Hydrologic \\
\hline Non-native species richness & 0.09 & -0.37 & -0.25 & -0.03 \\
Cover of native graminoids & 0.36 & 0.64 & 0.22 & 0.27 \\
Mean C-value of native species & -0.16 & -0.13 & -0.02 & -0.06 \\
$\begin{array}{l}\text { Cover-weighted Mean C-value } \\
\text { of all species }\end{array}$ & -0.12 & 0.35 & & \\
Cover-weighted Mean C-value & & & 0.38 & 0.10 \\
of native species & -0.31 & -0.10 & & \\
FQI of native species & 0.42 & 0.33 & -0.02 & -0.06 \\
Cover-weighted FQI of native & & & 0.25 & 0.02 \\
species & 0.27 & 0.19 & 0.12 & -0.03 \\
Wetland Index & -0.03 & -0.32 & -0.21 & 0.02 \\
\hline
\end{tabular}


Cover-weighted Mean C-value of all species showed a positive correlation with both the vegetation and Physicochemical attribute scores. Mean C-value of native species showed poor correlation with all Level 2 attributes as well as stressors and overall condition score. All FQA metrics showed poor correlation with the Hydrologic attribute score

\section{DISCUSSION}

The MTNHP completed digital wetland mapping for the southeastern Montana project area with funding from a companion EPA Wetland Program Development Grant as well as through funding from other partners. This mapping represents the first digital wetland data available for much of this area, allowing for up-to-date estimates of wetland acreage. Results from the wetland landscape profile revealed that wetlands are extremely limited in extent in the southeastern Montana project area, making up just $0.7 \%$ of the total project area. Palustrine wetlands with temporary or seasonal water regimes made up $65 \%$ of all mapped wetlands. These wetlands serve important water storage and groundwater recharge functions, as well as provide critical wildlife habitat, particularly early in the growing season. Wetland alterations in the project area were extensive with $43 \%$ of palustrine wetlands having some sort of anthropogenic alteration. These alterations were in the form of impoundments or excavations, primarily to increase water availability for livestock.

Private land access continues to be a challenge in aquatic resource monitoring (Leibowitz et al. 1991, Fellows and Buhl 1995, Adamus 2001). Over $79 \%$ of mapped palustrine wetlands in the project area occurred on privately owned lands, yet only 15\% of Level 2 assessment sites visited were on private land. In our original probabilistic selection of sites, the percentage of privately owned sites selected for assessment in each watershed ranged from $67 \%$ to $94 \%$; however, we were highly unsuccessful in receiving responses from and/or receiving permission to access sites from individual property owners. As a result, we had to make a second random selection of sites, limiting the target population to those wetlands occurring on public lands. Inability to access wetlands on private lands prohibited extrapolation of wetland condition across the population of wetlands in the project area.

Our Level 1 landscape characterization of the project area showed the primary land use is agricultural practices related to irrigated hay pastures and cropland. The Level 1 landscape characterization does not reflect the site-level impacts associated livestock grazing and hydrologic alterations.

Overall, 70\% of wetlands sampled with Level 2 assessments were classified as having a slight to moderate departure from reference standard. Another $19 \%$ of sampled wetlands had severe departures from reference standard. Over half of the wetlands assessed had observed impacts affecting physicochemical and Hydrologic attributes related to livestock grazing and impoundments and berms that impact wetland hydrology. Landscape context, particularly the buffer around the wetland, was also impacted by these impoundments as well as by unpaved roads. The cover of non-native species also affected the Vegetation attribute, although we did not differentiate these species based on their ecological amplitude, impact, or degree of invasiveness. 
We classified wetlands associated with impounded intermittent streams as emergent marsh, although some of these sites had drier water regimes than would typically be assigned to a marsh. Modifications to wetlands can alter several wetland characteristics including hydroperiod and vegetation composition and structure. These modifications can result in a change in wetland classification, making it difficult to differentiate variability due to environmental factors from variability in response to anthropogenic disturbance (Dvorett et al. 2013).

Most (77\%) of the native species observed during Level 3 wetland assessments had a C-value of $\leq 5$, indicating that most of the observed species were considered tolerant of moderate disturbance. As a result, we saw relatively poor or weak correlations between most of the FQA metrics that we calculated and overall wetland condition and stressors. In particular, FQA metrics were not correlated with the Hydrologic attribute, yet impacts to wetland hydrology had the strongest correlation with wetland condition. Additionally, small sample sizes within each Ecological System limited our ability to assess within-class relationships between FQA metrics and condition. Hence, our ability to minimize the potential effects of natural variability on FQA metrics was also limited.

Because we do not have C-values that were developed for wetland species in eastern Montana, we incorporated a wetness index into our FQA metrics, which considers the wetland indicator status of native species. We observed poor correlation between this metric and overall wetland condition and poor correlation between wetness index and disturbance. One possible explanation is that sites with hydrological alterations have artificially increased hydroperiods, influencing the occurrence of wetland plant species at these sites.

In previous studies in the Northern Glaciated Plains, we also observed poor correlations between FQA metrics and wetland condition (McIntyre et al. 2011, Newlon and Vance 2011). Wetland plant species in the semi-arid Plains evolved with a high degree of natural disturbance and widely fluctuating climatic conditions, so it is unsurprising that many of the native plant species present in these environments are relatively tolerant of disturbance. Additionally, these FQA metrics may covary with both environmental variation and anthropogenic disturbances, limiting the utility of these metrics in assessing wetland condition (Wilcox et al. 2002, Euliss and Mushet 2011). In these drought-prone environments that can experience dramatic climatic fluctuations both seasonally and annually, it is difficult to develop indices of floristic integrity that are relatively insensitive to seasonal and inter-annual environmental variation (Johnston et al. 2008, Euliss and Mushet 2011, Wilson et al. 2013). In particular, chemical and physical properties associated with wetland soils may provide an additional tool to assess wetland condition (Reddy and Clark 2008, Rokosch et al. 2009, Stapanian et al. 2013). Because many soil properties take decades to develop and can reflect average wetland conditions over many years (National Research Council 1995), they are relatively insensitive to rapid temporal changes associated with precipitation and other environmental variables. Further refinement of our EIA protocol to examine both biotic and abiotic characteristics of wetlands may be advantageous in these environments to adequately partition the response of wetland vegetation to anthropogenic disturbances. 


\section{LITERATURE CITED}

Adamus, P. R., T. J. Danielson, and A. Gonyaw. 2001. Indicators of monitoring biological integrity of inland freshwater wetlands: a survey of North American Technical Literature (1990-2000). Office of Wetlands, Oceans, and Watersheds, U.S. Environmental Protection Agency, Washington, D.C. EPA-843-R-01.

Andreas, B. K., J. J. Mack, and J. S. McCormac. 2004. Floristic quality assessment index (FQAI) for vascular plants and mosses for the State of Ohio. Ohio Environmental Protection Agency, Division of Surface Water, Wetland Ecology Group, Columbus, Ohio.

Brinson, M. M. 1993. A hydrogeomorphic classification for wetlands. Technical Report WRPDE-4, Waterways Experiment Station, Army Corps of Engineers, Vicksburg, Mississippi.

California Wetlands Monitoring Workgroup (CWMW). 2013. California Rapid Assessment Method (CRAM) for Wetlands, version 6.1.

Comer, P., D. Faber-Langendoen, R. Evans, S. Gawler, C. Josse, G. Kittel, S. Menard, M. Pyne, M. Reid, K. Schulz, K. Snow, and J. Teague. 2003. Ecological Systems of the United States: A Working Classification of U.S. Terrestrial Systems. NatureServe, Arlington, VA.

Cowardin, L. M., V. Carter, F. C. Golet, and E. T. LaRoe. 1979. Classification of wetlands and deepwater habitats of the United States. U.S. Fish and Wildlife Service, Washington, D.C. FWS/OBS-79/31.

Cronk, J. K., M. S. Fennessy. 2001. Wetlands plants: biology and ecology. CRC Press, Boca Raton, FL.

Dorn, R. D. 1984. Vascular plants of Montana. Mountain West Publishing, Cheyenne, WY.

Dvorett, D., J. Bidwell, C. Davis, and C. DuBois. 2013. Assessing natural and anthropogenic variability in wetland structure for two hydrogeomorphic riverine wetland subclasses. Environmental Management 52:1009-1022.

Engle, M. A., L. F. Radke, E. L. Heffern, J. M. K. O’Keefe, J. C. Hower, C. D. Smeltzer, J. M. Hower, R. A. Olea, R. J. Eatwell, D. R. Blake, S. D. Emsbo-Mattingly, S. A. Stout, G. Queen, K. L. Aggen, A. Kolker, A. Prakash, K. R. Henke, G. B. Stracher, P. A. Schroeder, Y. Roman-Colon, A. ter Schure. 2012. Gas emissions, minerals, and tars associated with three coal fires, Powder River Basin, USA. Science of the Total Environment 420:146-159.

Euliss, N. H., Jr., and D. M. Mushet. 2011. A multi-year comparison of IPCI scores for prairie pothole wetlands: implications of temporal and spatial variation. Wetlands. Advanced online publication. DOI: 10.1007/s13157-011-0187-2. 
Faber-Langendoen, D., C. Hedge, M. Kost, S. Thomas, L. Smart, R. Smyth, J. Drake, and S. Menard, 2011. Assessment of wetland ecosystem condition across landscape regions: a multi-metric approach. NatureServe, Arlington, VA. + Appendices.

Fellows, D. P., and T. K. Buhl. 1995. Research access to privately owned wetland basins in the Prairie Pothole Region of the United States. Wetlands 15:330-335.

Grossman, D. H., D. Faber-Langendoen, A. S. Weakley, M. Anderson, P. Bourgeron, R. Crawford, K. Goodin, S. Landaal, K. Metzler, K. D. Patterson, M. Pyne, M. Reid, and L. Sneddon. 1998. International classification of ecological communities: terrestrial vegetation of the United States. Volume I. The National Vegetation Classification System: development, status, and applications. The Nature Conservancy, Arlington, Virginia, USA.

Hauer, F. R., B. J. Cook, M. C. Gilbert, E. J. Clairain, Jr., and R. D. Smith. 2002. A regional guidebook for applying the hydrogeomorphic approach to assessing wetland functions of intermontane prairie pothole wetlands in the northern Rocky Mountains. ERDC/EL TR$02-7$.

Herman, K. D., L. A. Masters, M. R. Penskar, A. A. Reznicek, G. S. Wilhelm, and W. W. Brodowicz. 1997. Floristic quality assessment: development and application in the State of Michigan (USA). Natural Areas Journal 17:256-279.

Johnson, B. 2005. Hydrogeomorphic wetland profiling: an approach to landscape and cumulative impacts analysis. EPA/620/R05/001. U.S. Environmental Protection Agency, Washington, D.C.

Johnston, C. A., D. M. Ghicoa, M. Tulbure, B. L. Bedford, M. Bourdaghs, C. B. Frieswyk, L. Vaccaro, and J. B. Zedler. 2008. Partitioning vegetation response to anthropogenic stress to develop multi-taxa wetland indicators. Ecological Applications 18:983-1001.

Kincaid, T., and T. Olsen. 2009. spsurvey: Spatial survey design and analysis. R package version 2.1.

Lemly, J. L., and J. Rocchio. 2009. Vegetation index of biotic integrity (VIBI) for headwater wetlands in the southern Rocky Mountains. Version 2.0: Calibration of selected VIBI models. Colorado Natural Heritage Program.

Leibowitz, N., L. Squires, and J. Baker, 1991. Research plan for monitoring wetland ecosystems. EPA/600/3-91/010. US Environmental Protection Agency, Environmental Research Laboratory, Corvallis, Oregon 157 pp plus appendices.

Lichvar, R.W. 2012. The national wetland plant list. ERDC/CRREL TR-12-11. U.S. Army Engineer Research and Development Center, Cold Regions Research and Engineering Laboratory, Hanover, New Hampshire. 
Mack, J. J. 2001. Ohio Rapid Assessment Method for Wetlands, manual for using version 5.0. Ohio EPA Technical Bulletin Wetland/2001-1-1. Ohio Environmental Protection Agency, Division of Surface Water, 401 Wetland Ecology Unit, Columbus, Ohio.

Mack, J. J. 2004. Integrated Wetland Assessment Program. Part 4: Vegetation Index of Biotic Integrity (VIBI) and Tiered Aquatic Life Uses (TALUs) for Ohio wetlands. Ohio EPA Technical Report WET/2004-4. Ohio Environmental Protection Agency, Wetland Ecology Group, Division of Surface Water, Columbus, Ohio.

McIntyre, C., K. R. Newlon, L. K.Vance, and M. D. Burns. 2011. Milk, Marias, and St. Mary monitoring: developing a long-term rotating basin wetland assessment and monitoring strategy for Montana. Helena, Montana: Montana Natural Heritage Program.

McNab, W. H., and P. E. Avers, eds. 1994. Ecological subregions of the United States: section descriptions. U.S. Department of Agriculture, Forest Service. Publication WO-WSA-5, Washington, D.C.

Miller, S. J., and D. H. Wardrop. 2006. Adapting a floristic quality assessment index to indicate anthropogenic disturbance in central Pennsylvania wetlands. Ecological Indicators 6:313-326.

Montana Natural Heritage Program (MTNHP). 2011. Montana Ecological Integrity Assessment Field Manual.

Montana Natural Heritage Program (MTNHP). 2013. Montana Land Cover/Land Use Theme. Based on classifications originally developed by the University of Idaho, Sanborn and the MTNHP for the Pacific Northwest ReGAP project. Helena, Montana.

Munsell Color Company. 2000. Munsell Soil Color Charts. Revised washable edition. New Windsor, Gretag Macbeth.

National Research Council. 1995. Wetlands: characteristics and boundaries. National Academy Press, Washington D.C., USA.

Newlon, K. R., and L. K. Vance. 2011. A reference wetland network for assessment and monitoring of Montana's herbaceous wetlands. Report to the U.S. Environmental Protection Agency. Montana Natural Heritage Program, Helena, Montana. 23 pp. plus appendices.

Northern Great Plains Floristic Quality Assessment Panel. 2001. Floristic quality assessment for plant communities of North Dakota, South Dakota (excluding the Black Hills), and adjacent grasslands. Jamestown, ND: Northern Prairie Wildlife Research Center Online. http://www.npwrc.usgs.gov/resource/plants/fqa/index.htm (Version 26JAN2001).

Omernik, J. M. 1987. Ecoregions of the conterminous United States. Map (scale 1:7,500,00). Annals of the Association of American Geographers 77:118-125. 
Peet, R.K., T.R. Wentworth, and P.S. White. 1998. A flexible, multipurpose method for recording vegetation composition and structure. Castanea 63: 262-274.

R Development Core Team. 2009. R: A language and environment for statistical computing. R Foundation for Statistical Computing, Vienna, Austria. ISBN 3-900051-07-0, URL http://www.R-project.org.

Reddy, K. R., and M. W. Clark. 2008. Methods for evaluating wetland condition: biogeochemical indicators. Office of Wetlands, Oceans, and Watersheds, U.S. Environmental Protection Agency, Washington, D.C., EPA-822-R-08-022.

Rocchio, J. 2006. Vegetation index of biotic integrity for Southern Rocky Mountain fens, wet meadows, and riparian shrublands: phase 1 final report. Unpublished report prepared for the Colorado Department of Natural Resources and US EPA Region 8. Colorado Natural Heritage Program, Colorado State University, Fort Collins, Colorado.

Rocchio, J. 2007. Assessing ecological condition of headwater wetlands in the Southern Rocky Mountains using a vegetation index of biotic integrity. (Version 1.0). Unpublished report prepared for the Colorado Department of Natural Resources and US EPA Region 8. Colorado Natural Heritage Program, Colorado State University, Fort Collins, Colorado.

Rokosch, A. E., V. Bouchard, S. Fennessy, and R. Dick. 2009. The use of soil parameters as indicators of quality in forested depressional wetlands. Wetlands 29:666-677.

Stapanian, M. A., J. V. Adams, M. S. Fennessy, J. Mack, and M. Micacchion. 2013. Candidate soil indicators for monitoring the progress of constructed wetlands toward a natural state: a statistical approach. Wetlands. Advanced online publication. DOI: 10.1007/s13157013-0464-3.

Stevens, D.L., Jr., and A.R. Olsen. 2004. Spatially balanced sampling of natural resources. Journal of American Statistical Association 99:262-278.

Stevens, D. L. Jr., and S. F. Jensen. 2007. Sample design, execution, and analysis for wetland assessment. Wetlands 27:515-523.

Sutula, M. A., E. D. Stein, J. N. Collins, A. E. Fetscher, and R. Clark. 2006. A practical guide for the development of a wetland assessment method: the California experience. Journal of the American Water Resources Association 42:157-175.

U.S. Army Corps of Engineers. 2010. Regional supplement to the Corps of Engineers Wetland Delineation Manual: western mountains, valleys, and coast region (Version 2.0), J.S. Wakeley, R. W. Lichvar, and C. V. Noble (eds.). ERDC.EL TR-10-3. Vicksburg, Mississippi: U.S. Army Engineer Research and Development Center. 
Wilcox, D. A., J. E. Meeker, P. L. Hudson, B. J. Armitage, M. G. Black, and D. G. Uzarski. 2002. Hydrologic variability and the application of the index of biotic integrity metrics to wetlands: a Great Lakes evaluation. Wetlands 22:588-615. 
Appendix A. National Wetland Inventory (NWI) attribute codes included in the southeastern Montana basin-wide wetland assessment sample frame.

\begin{tabular}{|c|c|c|c|c|}
\hline Attribute & System & Class & Regime & Modifier \\
\hline PABF & Palustrine & Aquatic Bed & Semipermanently Flooded & \\
\hline PABFb & Palustrine & Aquatic Bed & Semipermanently Flooded & Beaver \\
\hline PABFh & Palustrine & Aquatic Bed & Semipermanently Flooded & Diked/Impounded \\
\hline PABFx & Palustrine & Aquatic Bed & Semipermanently Flooded & Excavated \\
\hline PABG & Palustrine & Aquatic Bed & Intermittently Exposed & \\
\hline PABGb & Palustrine & Aquatic Bed & Intermittently Exposed & Beaver \\
\hline PABGh & Palustrine & Aquatic Bed & Intermittently Exposed & Diked/Impounded \\
\hline PEMA & Palustrine & Emergent & Temporarily Flooded & \\
\hline PEMAd & Palustrine & Emergent & Temporarily Flooded & Partially Drained/Ditched \\
\hline PEMAh & Palustrine & Emergent & Temporarily Flooded & Diked/Impounded \\
\hline PEMAx & Palustrine & Emergent & Temporarily Flooded & Excavated \\
\hline PEMB & Palustrine & Emergent & Saturated & \\
\hline PEMBb & Palustrine & Emergent & Saturated & Beaver \\
\hline PEMC & Palustrine & Emergent & Seasonally Flooded & \\
\hline PEMCh & Palustrine & Emergent & Seasonally Flooded & Diked/Impounded \\
\hline PEMCx & Palustrine & Emergent & Seasonally Flooded & Excavated \\
\hline PEMF & Palustrine & Emergent & Semipermanently Flooded & \\
\hline PEMFh & Palustrine & Emergent & Semipermanently Flooded & Diked/Impounded \\
\hline PEMFx & Palustrine & Emergent & Semipermanently Flooded & Excavated \\
\hline PFOA & Palustrine & Forested & Temporarily Flooded & \\
\hline PFOAh & Palustrine & Forested & Temporarily Flooded & Diked/Impounded \\
\hline PFOAx & Palustrine & Forested & Temporarily Flooded & Excavated \\
\hline PFOB & Palustrine & Forested & Saturated & \\
\hline PFOBb & Palustrine & Forested & Saturated & Beaver \\
\hline PSSA & Palustrine & Scrub-Shrub & Temporarily Flooded & \\
\hline PSSAh & Palustrine & Scrub-Shrub & Temporarily Flooded & Diked/Impounded \\
\hline PSSAx & Palustrine & Scrub-Shrub & Temporarily Flooded & Excavated \\
\hline PSSB & Palustrine & Scrub-Shrub & Saturated & \\
\hline $\mathrm{PSSBb}$ & Palustrine & Scrub-Shrub & Saturated & Beaver \\
\hline PSSBd & Palustrine & Scrub-Shrub & Saturated & Partially Drained/Ditched \\
\hline PSSC & Palustrine & Scrub-Shrub & Seasonally Flooded & \\
\hline PSSCh & Palustrine & Scrub-Shrub & Seasonally Flooded & Diked/Impounded \\
\hline
\end{tabular}


Appendix B. Palustrine National Wetland Inventory (NWI) attribute codes excluded from the southeastern Montana basin-wide wetland assessment sample frame.

\begin{tabular}{|l|l|l|l|l|}
\hline Attribute & System & \multicolumn{1}{c|}{ Class } & \multicolumn{1}{c|}{ Regime } & \multicolumn{1}{c|}{ Modifier } \\
\hline PUBF & Palustrine & Unconsolidated Bottom & Semipermanently Flooded & \\
\hline PUBFx & Palustrine & Unconsolidated Bottom & Semipermanently Flooded & Excavated \\
\hline PUBG & Palustrine & Unconsolidated Bottom & Intermittently Exposed & \\
\hline PUSA & Palustrine & Unconsolidated Shore & Temporarily Flooded & \\
\hline PUSAh & Palustrine & Unconsolidated Shore & Temporarily Flooded & Diked/Impounded \\
\hline PUSAx & Palustrine & Unconsolidated Shore & Temporarily Flooded & Excavated \\
\hline PUSC & Palustrine & Unconsolidated Shore & Seasonally Flooded & \\
\hline PUSCd & Palustrine & Unconsolidated Shore & Seasonally Flooded & Partially Drained/Ditched \\
\hline PUSCh & Palustrine & Unconsolidated Shore & Seasonally Flooded & Diked/Impounded \\
\hline PUSCx & Palustrine & Unconsolidated Shore & Seasonally Flooded & Excavated \\
PABKx & Palustrine & Aquatic Bed & Artificially Flooded & Excavated \\
\hline
\end{tabular}


Appendix C. Lacustrine and riverine National Wetland Inventory (NWI) attribute codes excluded from the southeastern Montana basin-wide wetland assessment sample frame.

\begin{tabular}{|c|c|c|c|c|c|}
\hline \begin{tabular}{|l} 
Attribute \\
\end{tabular} & System & Subsystem & Class & Regime & Modifier \\
\hline L1UBG & Lacustrine & Limnetic & Unconsolidated Bottom & Intermittently Exposed & \\
\hline L1UBH & Lacustrine & Limnetic & Unconsolidated Bottom & Permanently Flooded & \\
\hline L1UBHh & Lacustrine & Limnetic & Unconsolidated Bottom & Permanently Flooded & Diked/Impounded \\
\hline $\mathrm{L} 2 \mathrm{ABF}$ & Lacustrine & Littoral & Aquatic Bed & Semipermanently Flooded & \\
\hline L2ABFh & Lacustrine & Littoral & Aquatic Bed & Semipermanently Flooded & Diked/Impounded \\
\hline $\mathrm{L} 2 \mathrm{ABG}$ & Lacustrine & Littoral & Aquatic Bed & Intermittently Exposed & \\
\hline $\mathrm{L} 2 \mathrm{ABGh}$ & Lacustrine & Littoral & Aquatic Bed & Intermittently Exposed & Diked/Impounded \\
\hline L2UBF & Lacustrine & Littoral & Unconsolidated Bottom & Semipermanently Flooded & \\
\hline L2UBG & Lacustrine & Littoral & Unconsolidated Bottom & Intermittently Exposed & \\
\hline L2USA & Lacustrine & Littoral & Unconsolidated Shore & Temporarily Flooded & \\
\hline L2USAh & Lacustrine & Littoral & Unconsolidated Shore & Temporarily Flooded & Diked/Impounded \\
\hline L2USC & Lacustrine & Littoral & Unconsolidated Shore & Seasonally Flooded & \\
\hline L2USCh & Lacustrine & Littoral & Unconsolidated Shore & Seasonally Flooded & Diked/Impounded \\
\hline R2UBG & Riverine & Lower Perennial & Unconsolidated Bottom & Intermittently Exposed & \\
\hline R2UBH & Riverine & Lower Perennial & Unconsolidated Bottom & Seasonally Flooded & \\
\hline R2USA & Riverine & Lower Perennial & Unconsolidated Shore & Temporarily Flooded & \\
\hline R3UBF & Riverine & Upper Perennial & Unconsolidated Bottom & Semipermanently Flooded & \\
\hline R3UBFx & Riverine & Upper Perennial & Unconsolidated Bottom & Semipermanently Flooded & Excavated \\
\hline R3UBG & Riverine & Upper Perennial & Unconsolidated Bottom & Intermittently Exposed & \\
\hline R3UBH & Riverine & Upper Perennial & Unconsolidated Bottom & Seasonally Flooded & \\
\hline R3USA & Riverine & Upper Perennial & Unconsolidated Shore & Temporarily Flooded & \\
\hline R3USC & Riverine & Upper Perennial & Unconsolidated Shore & Seasonally Flooded & \\
\hline R4SBA & Riverine & Intermittent & Streambed & Temporarily Flooded & \\
\hline $\mathrm{R} 4 \mathrm{SBC}$ & Riverine & Intermittent & Streambed & Seasonally Flooded & \\
\hline R4SBCx & Riverine & Intermittent & Streambed & Seasonally Flooded & Excavated \\
\hline R4USA & Riverine & Intermittent & Unconsolidated Shore & Temporarily Flooded & \\
\hline
\end{tabular}


Appendix D. Scoring procedure for calculating stressor impact ratings (sensu Faber-Langendoen et al. 2011).

Table 1. Stressor impact ratings calculations.

\begin{tabular}{lllllllll}
\hline & & & \multicolumn{9}{c}{ Scope } \\
\hline \multirow{3}{*}{ Severity } & Pervasive & Large & Restricted & Moderate & Small & Nil \\
& Extreme & Very High & High & Medium & Medium & Low & Low \\
& Serious & High & High & Medium & Medium & Low & Low \\
& Moderate & Medium & Medium & Low & Low & Low & Low \\
& Slight & Low & Low & Low & Low & Low & Low \\
\hline
\end{tabular}

Table 2. Stressor impact rating numerical conversions.

\begin{tabular}{rrrrrrrrrr}
\hline & \multicolumn{10}{c}{ Scope } \\
\hline \multirow{4}{*}{ Severity } & $\mathbf{5}$ & $\mathbf{4}$ & $\mathbf{3}$ & $\mathbf{2}$ & $\mathbf{1}$ & \multicolumn{1}{c}{$\mathbf{0}$} \\
& $\mathbf{4}$ & 20 & & 16 & 12 & 8 & 4 & 0 \\
& $\mathbf{3}$ & 15 & & 12 & 9 & & 6 & 3 & 0 \\
& $\mathbf{2}$ & 10 & 8 & 6 & 4 & 2 & 0 \\
& $\mathbf{1}$ & 5 & 4 & 3 & 2 & 1 & 0 \\
\hline
\end{tabular}

Table 3. Rollup procedure for calculating an overall stressor impact rating.

\begin{tabular}{ll}
\hline Impact Values of Stressor Categories & Overall Stressor Rating \\
\hline 1 or more Very High Stressors, OR 2 or more & \\
High, OR 1 High + 2 or more Medium & Very High (1) \\
$\begin{array}{l}\text { 1 High Stressor, OR 3 or more Medium, OR 2 } \\
\text { Medium + 2 or more Low, OR 1 Medium, + 3 or }\end{array}$ & \\
more Low & High (2) \\
$\begin{array}{l}\text { 1 Medium Stressor + 5 or more Low, OR 8 or } \\
\text { more Low }\end{array}$ & Medium (3) \\
$\begin{array}{l}\text { 1 Medium Stressor + 1-4 Low, OR 1-7 Low } \\
\text { Stressors }\end{array}$ & Low (4) \\
0 Stressors & Absent (0) \\
\hline
\end{tabular}


Appendix E. Scoring formulas for Level 2 attribute and overall wetland condition scores.

1. For each metric, convert narrative rating score (1, 2, 3, 4, and 5) into the corresponding metric score: $1=12,2=9,3=6,4=3$, and $5=1$.If metric has only four narrative ratings, then $1=12,2=9$, $3=6,4=3$. If metric had only three narrative ratings, then $1=12,2=6$, and $3=1$.

2. Each final attribute score was calculated according to the following:

$\underline{\text { Landscape Context (LC) Attribute Score: }}$

Raw score $=[(($ Buffer Condition_Plants + Buffer Condition_Soils + Buffer

Condition_Trash)/3) $\left.x(\text { Buffer width } x \text { Buffer length })^{1 / 2}\right]^{1 / 2}+$ Landscape Connectivity

Final Attribute score $=\quad \frac{\text { Raw Landscape Context Score }}{\text { Total possible points allowed (24) }} \times 100$

Vegetation Attribute Score:

Raw score $=[(($ Invasive native + Native + Noxious $) / 3)+$ Litter or woody debris accumulation + Patch Interspersion $+(($ Woody vegetation $)+$ Browse $) / 2)]$

Final Attribute Score $=$

Raw Biotic Score x 100

Total possible points allowed (48)

Physicochemical Attribute Score:

Raw score $=[$ Soil Surface Integrity $+(($ Water Quality_Algae + Water Quality_Plants + Water Quality_Turbidity)/3)]

Final Attribute Score $=$

Raw Physicochemical Score x 100

Total possible points allowed (24)

Hydrology Attribute Score:

Raw score $=[($ Hydrologic Input + Hydrologic Output $) / 2)+$ Hydroperiod + Surface Water Connectivity scores

Final Attribute Score $=$ Raw Hydrology Score x 100

Total possible points allowed (36)

3. Final AA Score $=$ Final LC + Final Vegetation + Final Physico + Final Hydro/4 
Appendix F. Terminology, description, and calculation of the floristic quality assessment metrics.

$N_{n}=$ count of native species, $N_{a}=$ count of all species, $N_{e}=$ count of non-native species, $C_{i}=$ index of conservatism for the $i^{\text {th }}$ species, $x_{i}=$ percent cover for the $i^{\text {th }}$ species, $W=$ coefficient of wetness.

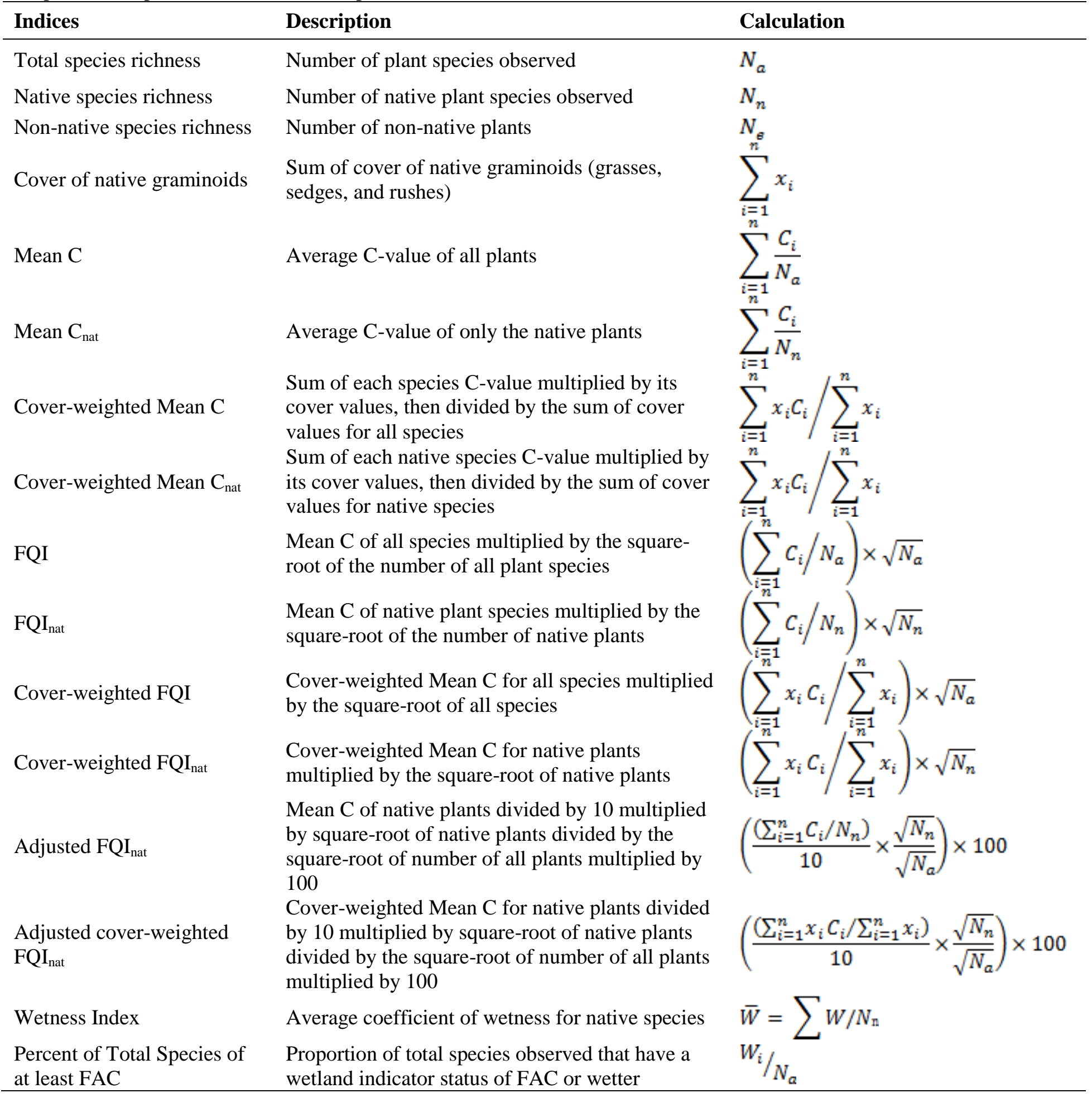


Appendix G. Wetland landscape profile for palustrine wetlands in the southeast Montana basinwide assessment project area.

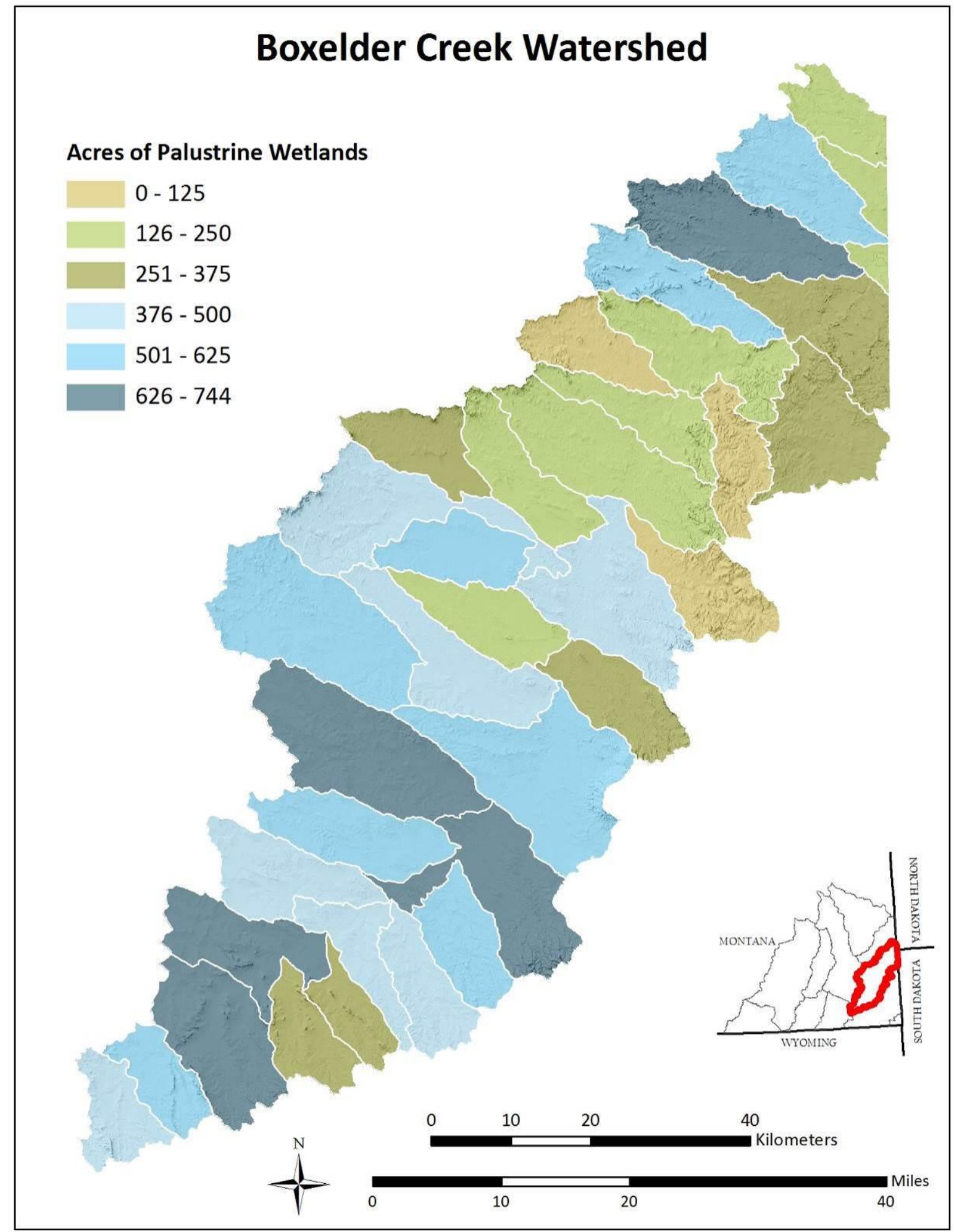

Figure 1. Acres of palustrine wetland by sixth code hydrologic unit in the Boxelder Creek watershed. 


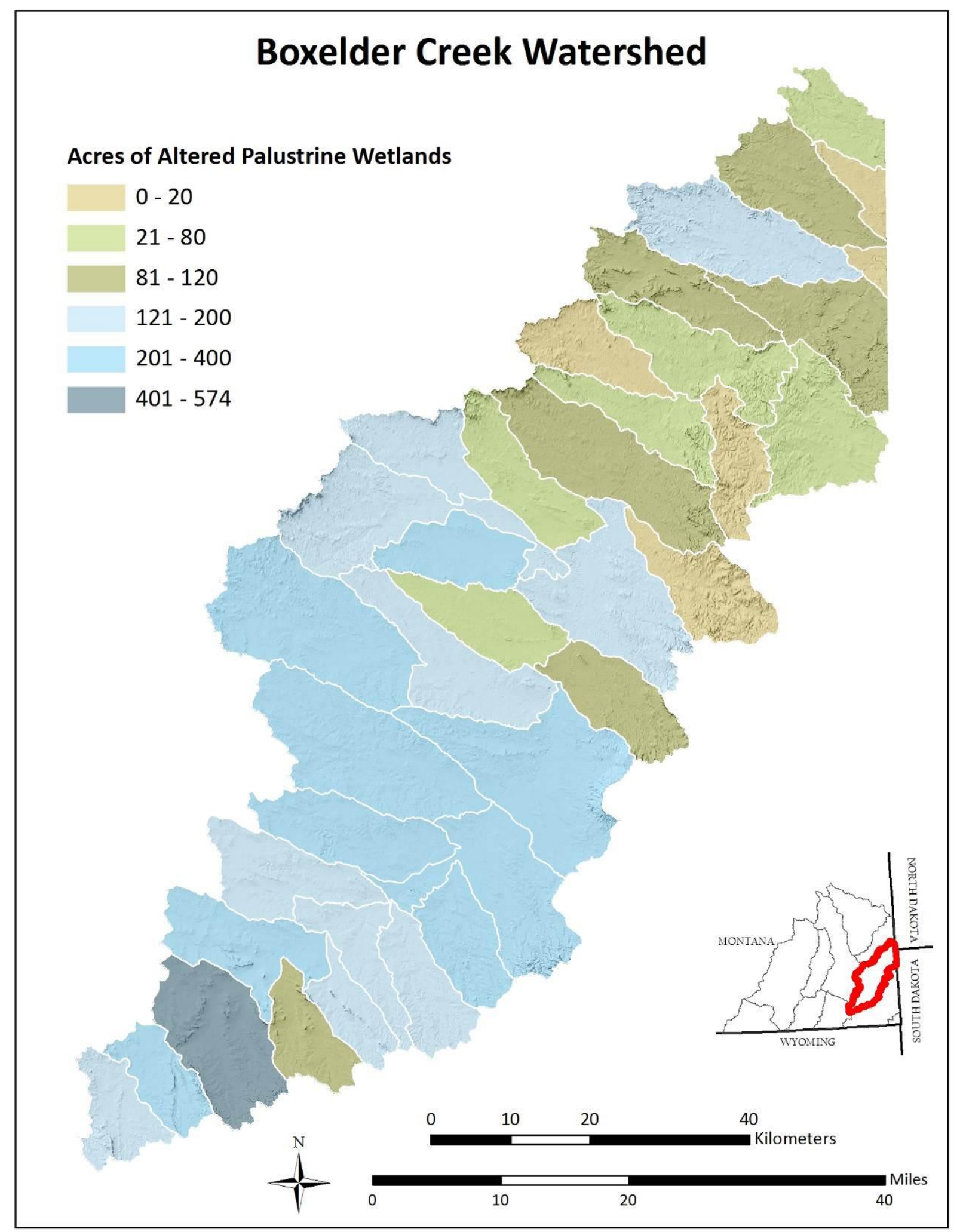

Figure 2. Acres of anthropogenically altered palustrine wetlands (i.e., ditched, drained, impounded, excavated, farmed) by sixth code hydrologic unit in the Boxelder Creek watershed. 


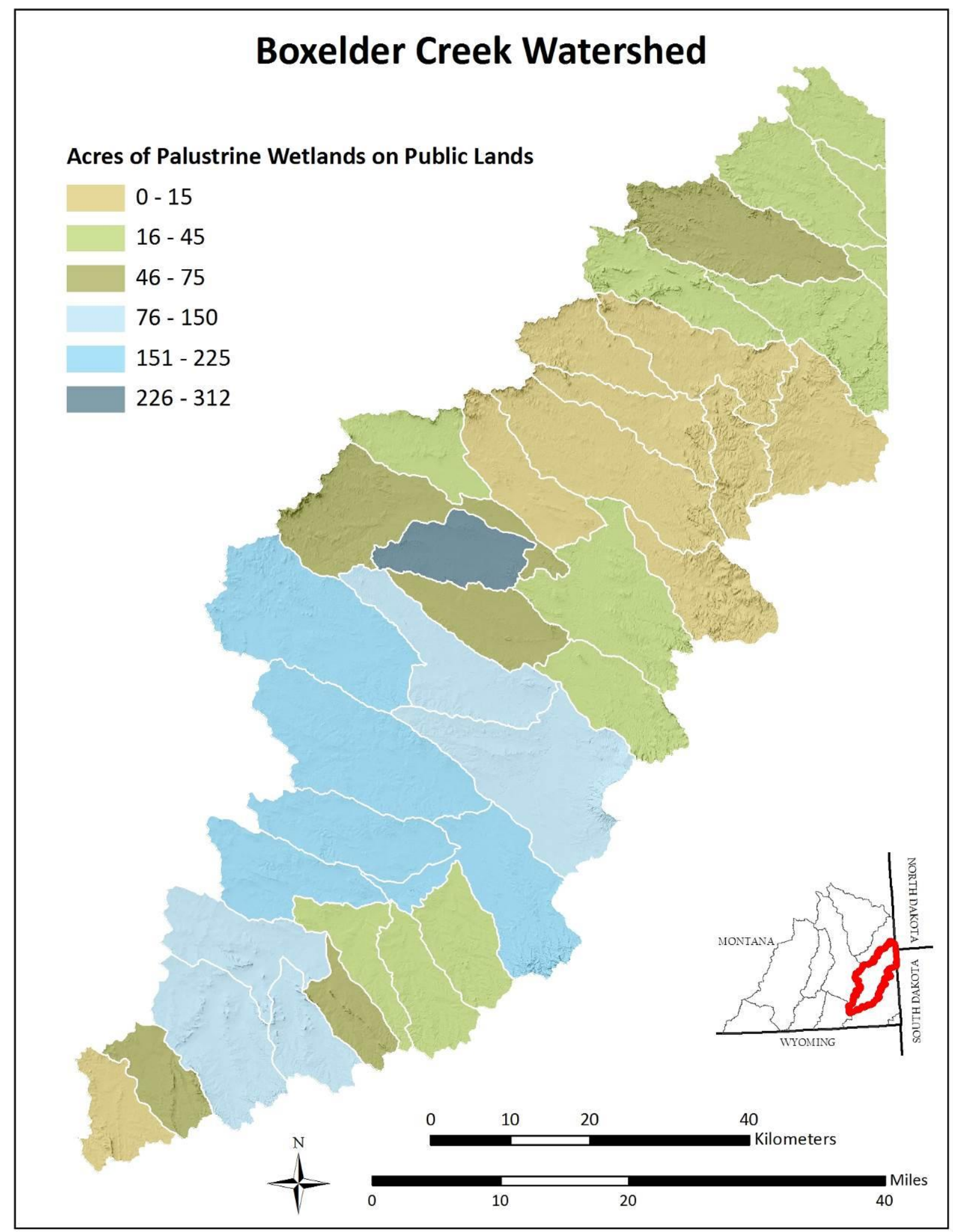

Figure 3. Acres of palustrine wetlands on publicly owned lands by sixth code hydrologic unit in the Boxelder Creek watershed. 


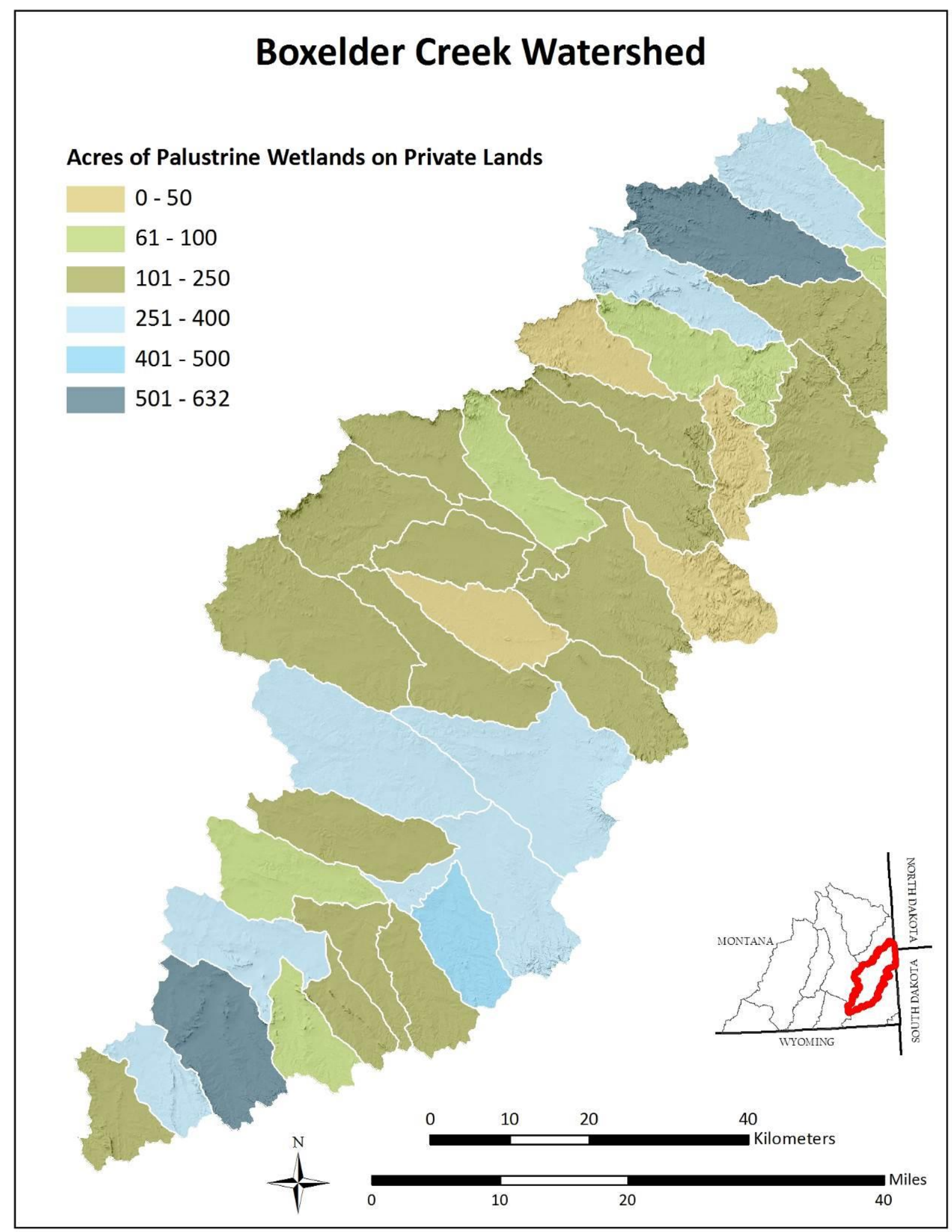

Figure 4. Acres of palustrine wetlands on privately owned lands by sixth code hydrologic unit in the Boxelder Creek watershed. 


\section{Little Powder River Watershed}

Acres of Palustrine Wetlands

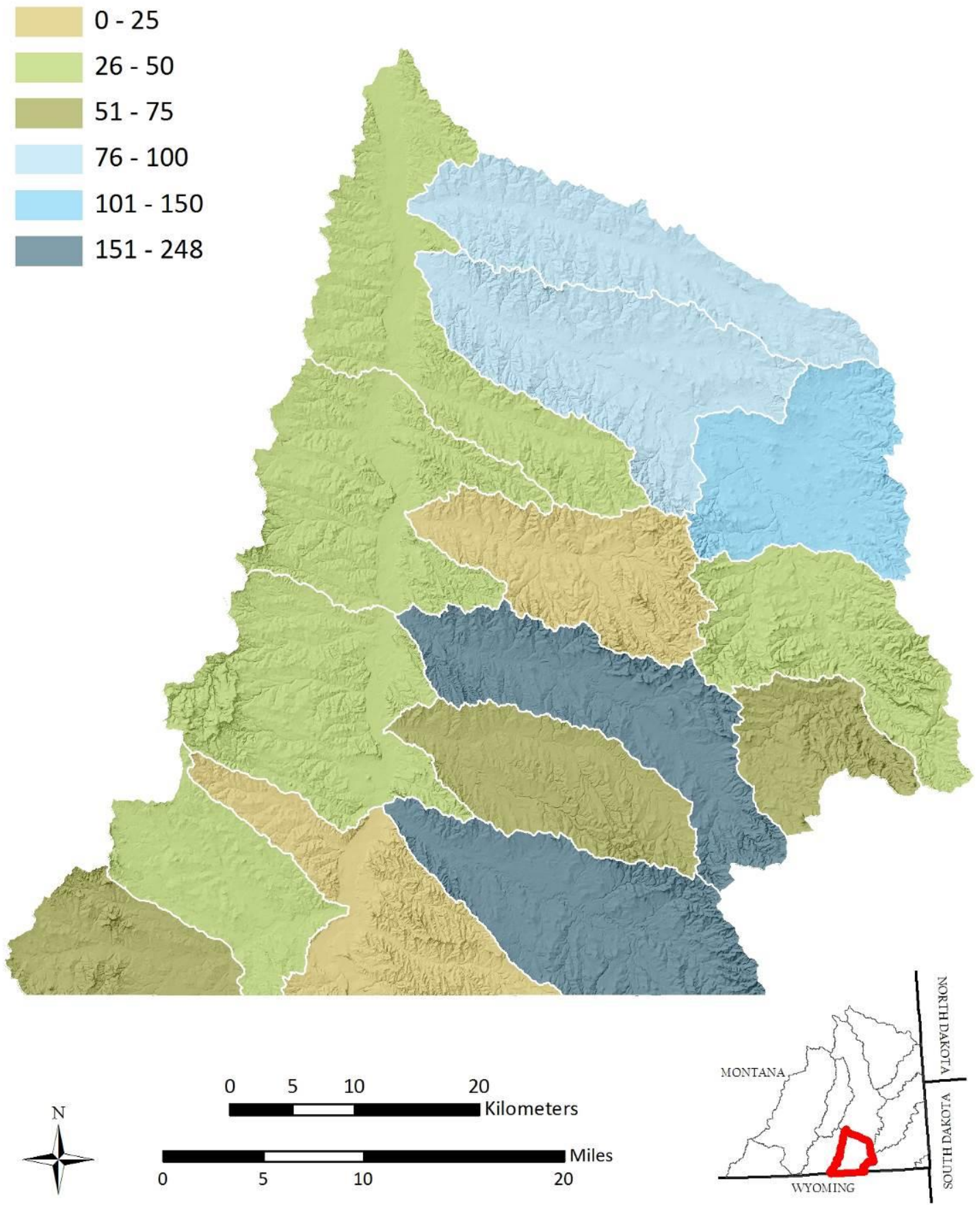

Figure 5. Acres of palustrine wetland by sixth code hydrologic unit in the Little Powder River watershed. 


\section{Little Powder River Watershed}

Acres of Altered Palustrine Wetlands

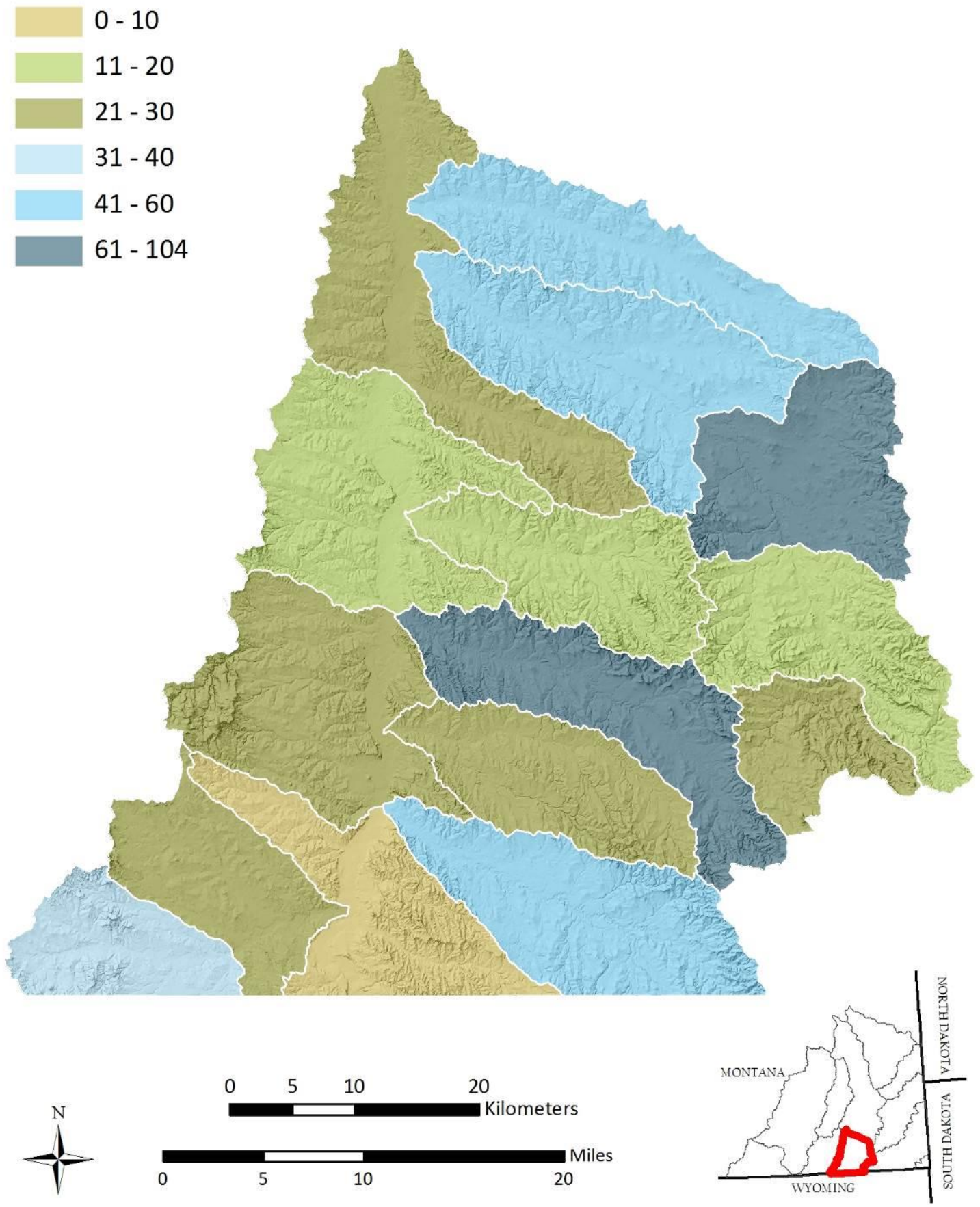

Figure 6. Acres of anthropogenically altered palustrine wetlands (i.e., ditched, drained, impounded, excavated, farmed) by sixth code hydrologic unit in the Little Powder River watershed. 


\section{Little Powder River Watershed}

Acres of Palustrine Wetlands on Public Lands

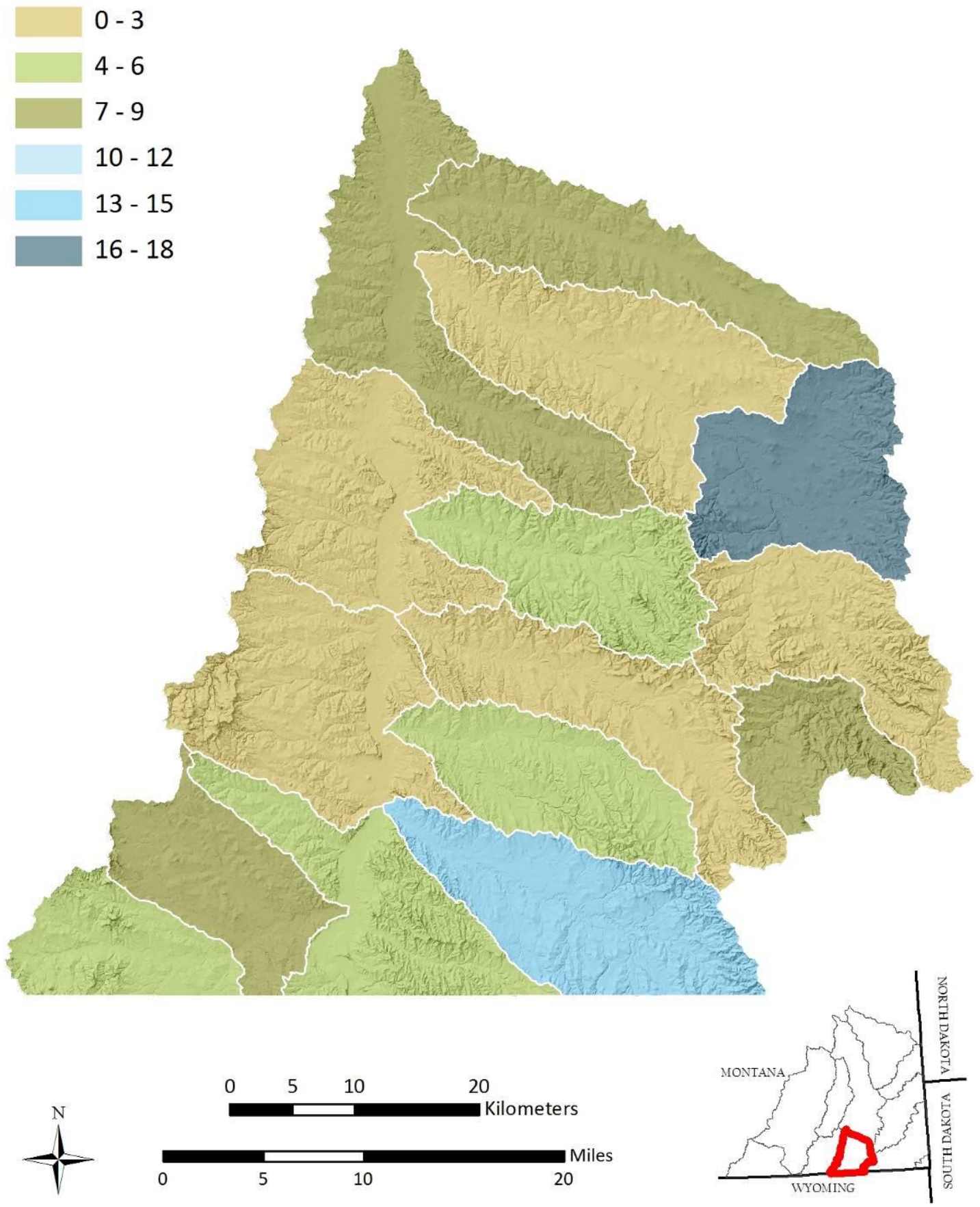

Figure 7. Acres of palustrine wetlands on publicly owned lands by sixth code hydrologic unit in the Little Powder River watershed. 


\section{Little Powder River Watershed}

\section{Acres of Palustrine Wetlands on Private Lands}

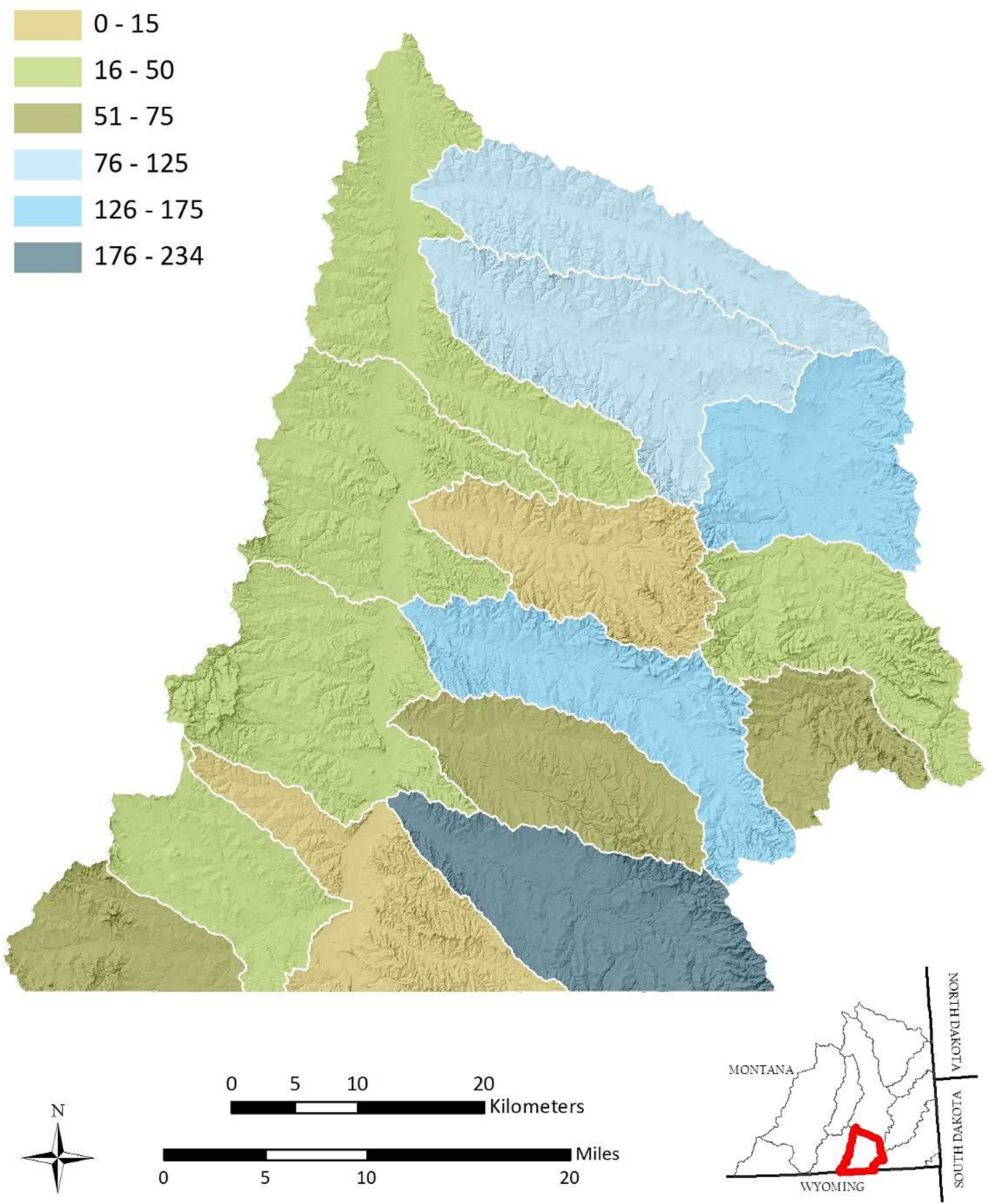

Figure 8. Acres of palustrine wetlands on privately owned lands by sixth code hydrologic unit in the Little Powder River watershed. 


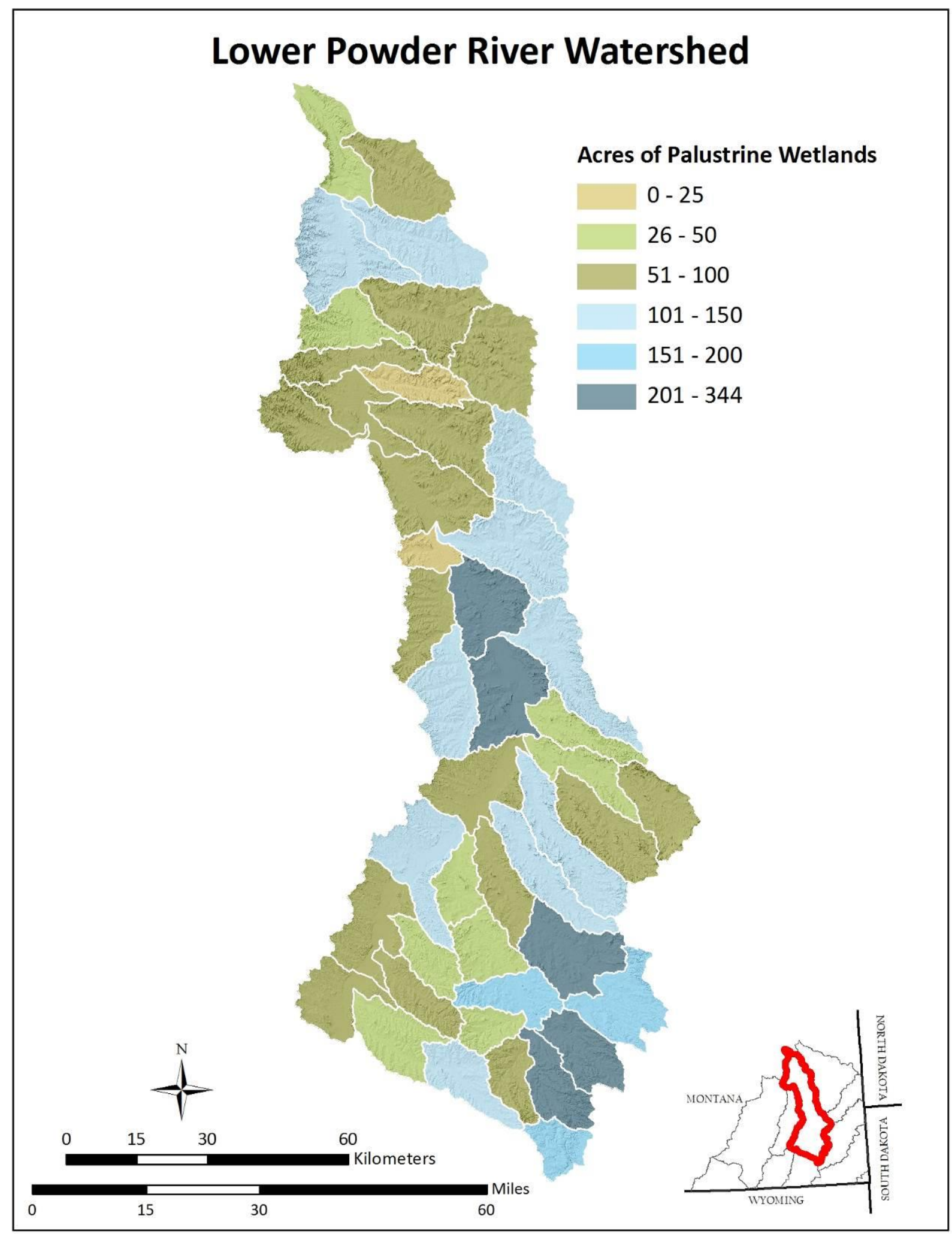

Figure 9. Acres of palustrine wetland by sixth code hydrologic unit in the Lower Powder River watershed. 


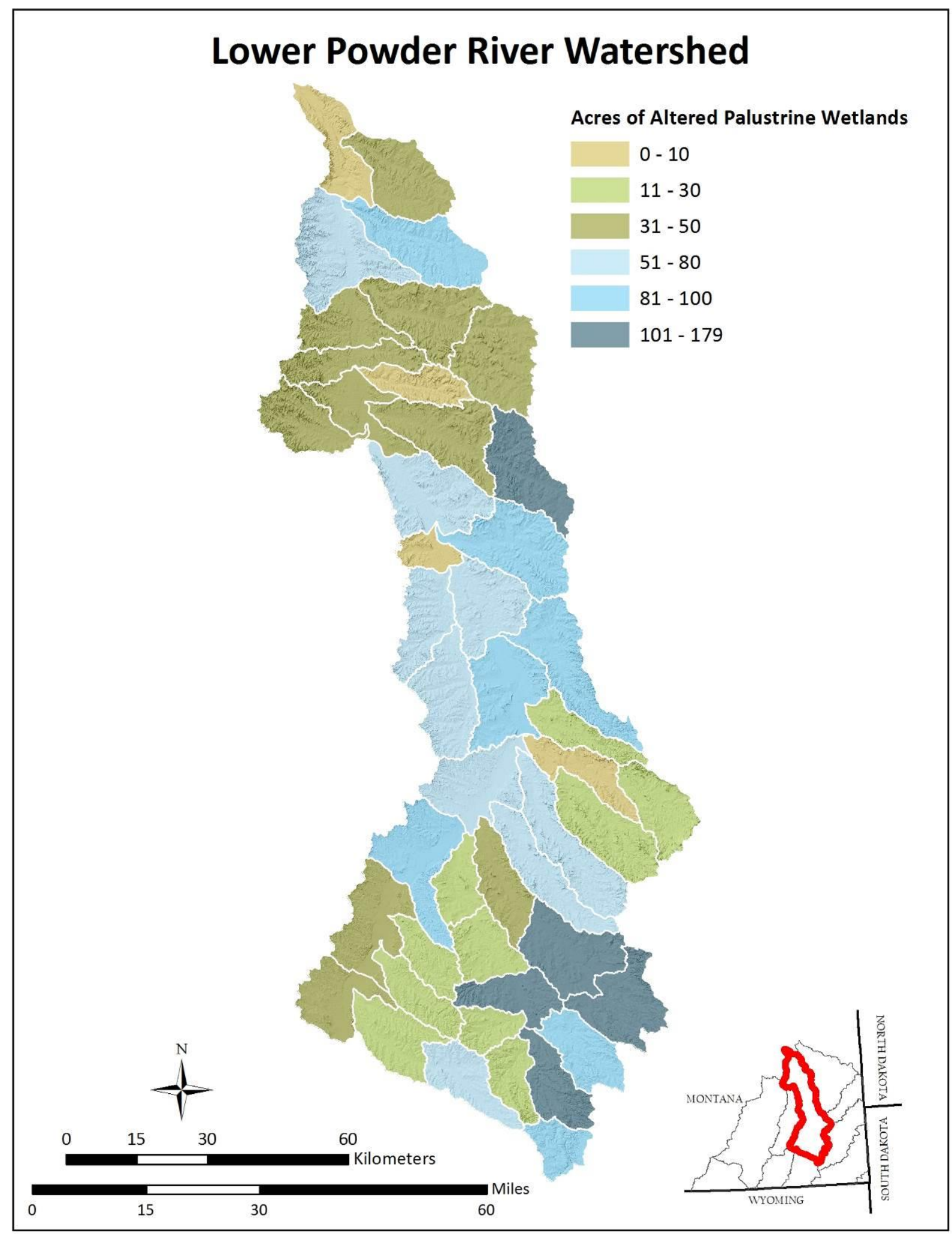

Figure 10. Acres of anthropogenically altered palustrine wetlands (i.e., ditched, drained, impounded, excavated, farmed) by sixth code hydrologic unit in the Lower Powder River watershed. 


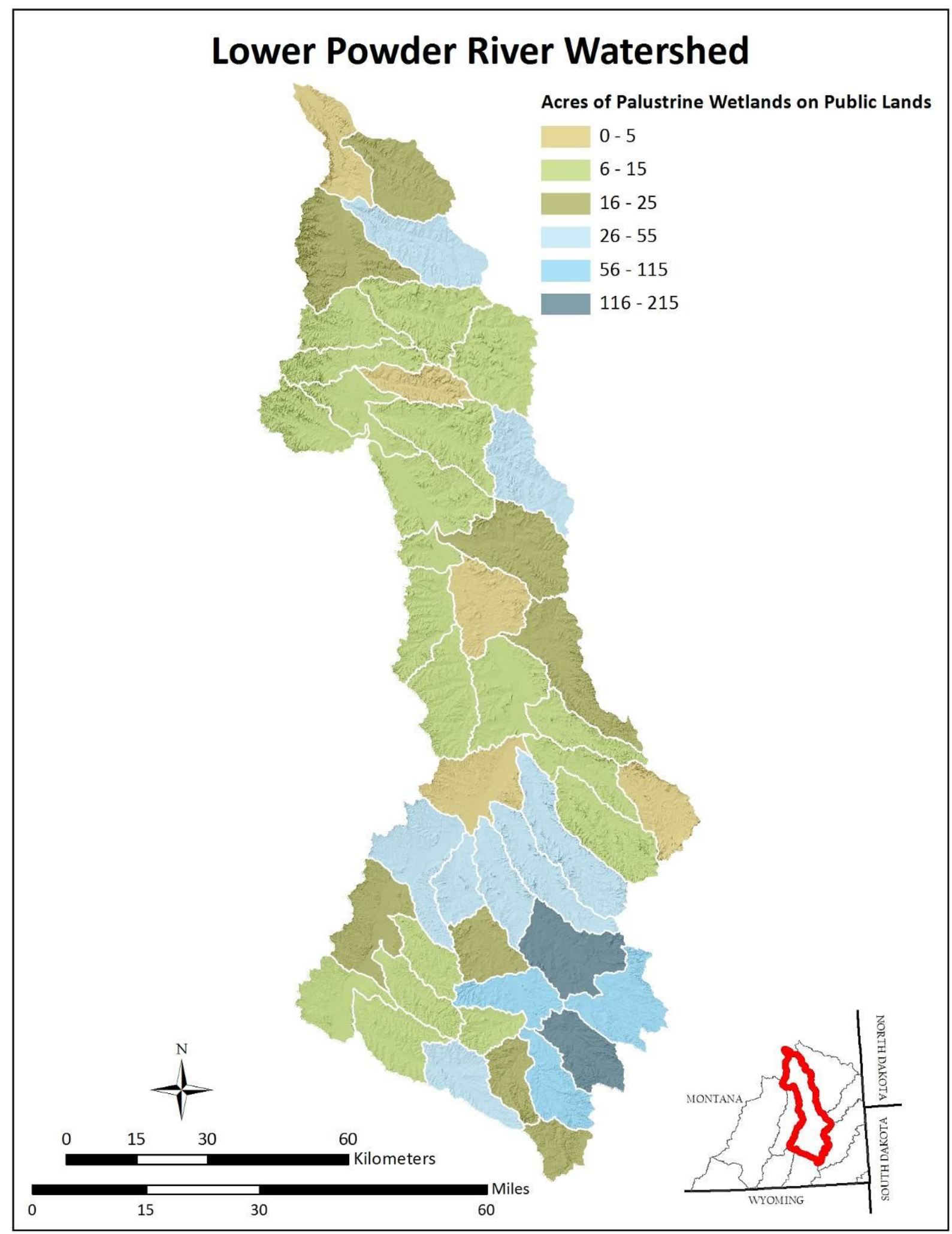

Figure 11. Acres of palustrine wetlands on publicly owned lands by sixth code hydrologic unit in the Lower Powder River watershed. 


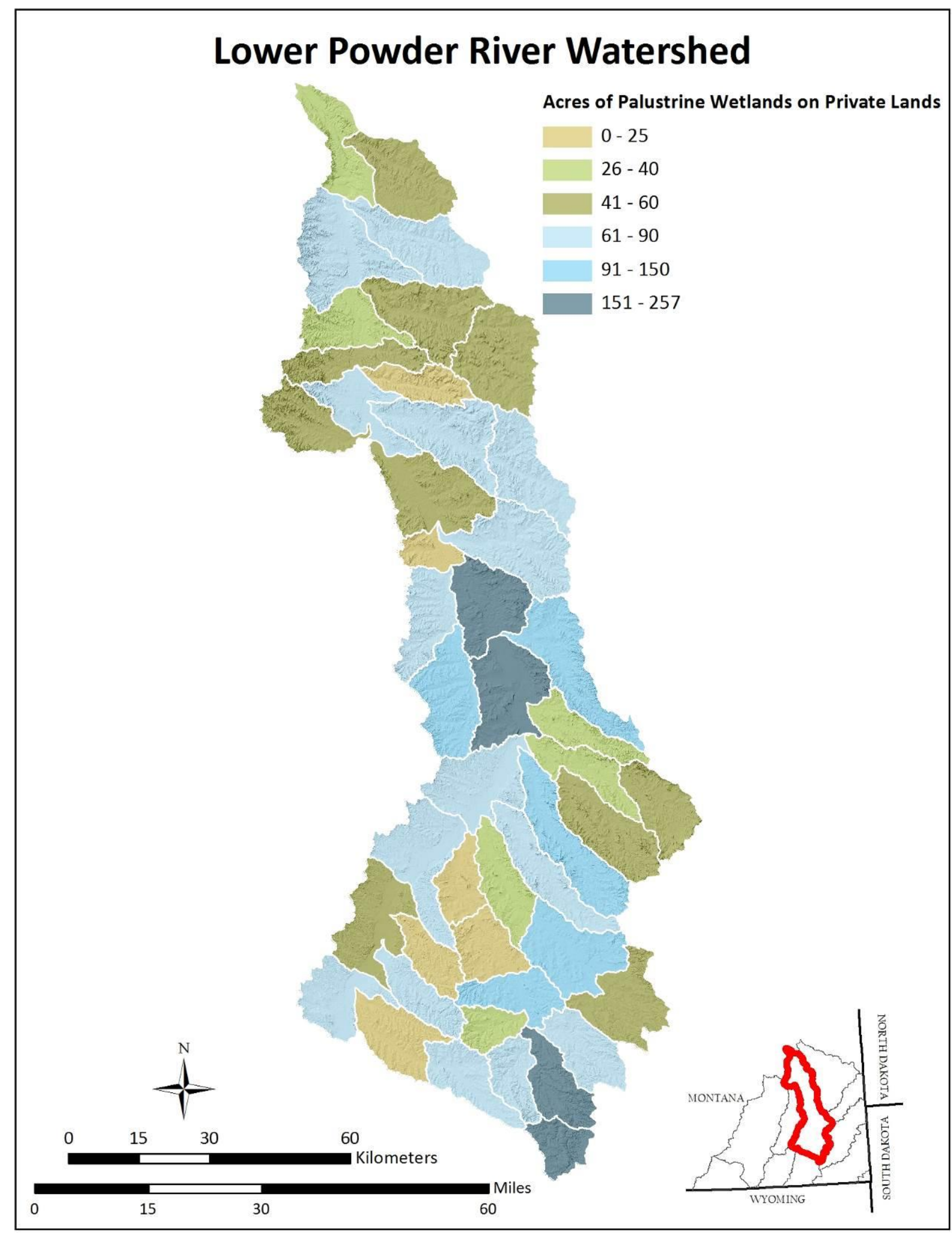

Figure 12. Acres of palustrine wetlands on privately owned lands by sixth code hydrologic unit in the Lower Powder River watershed. 


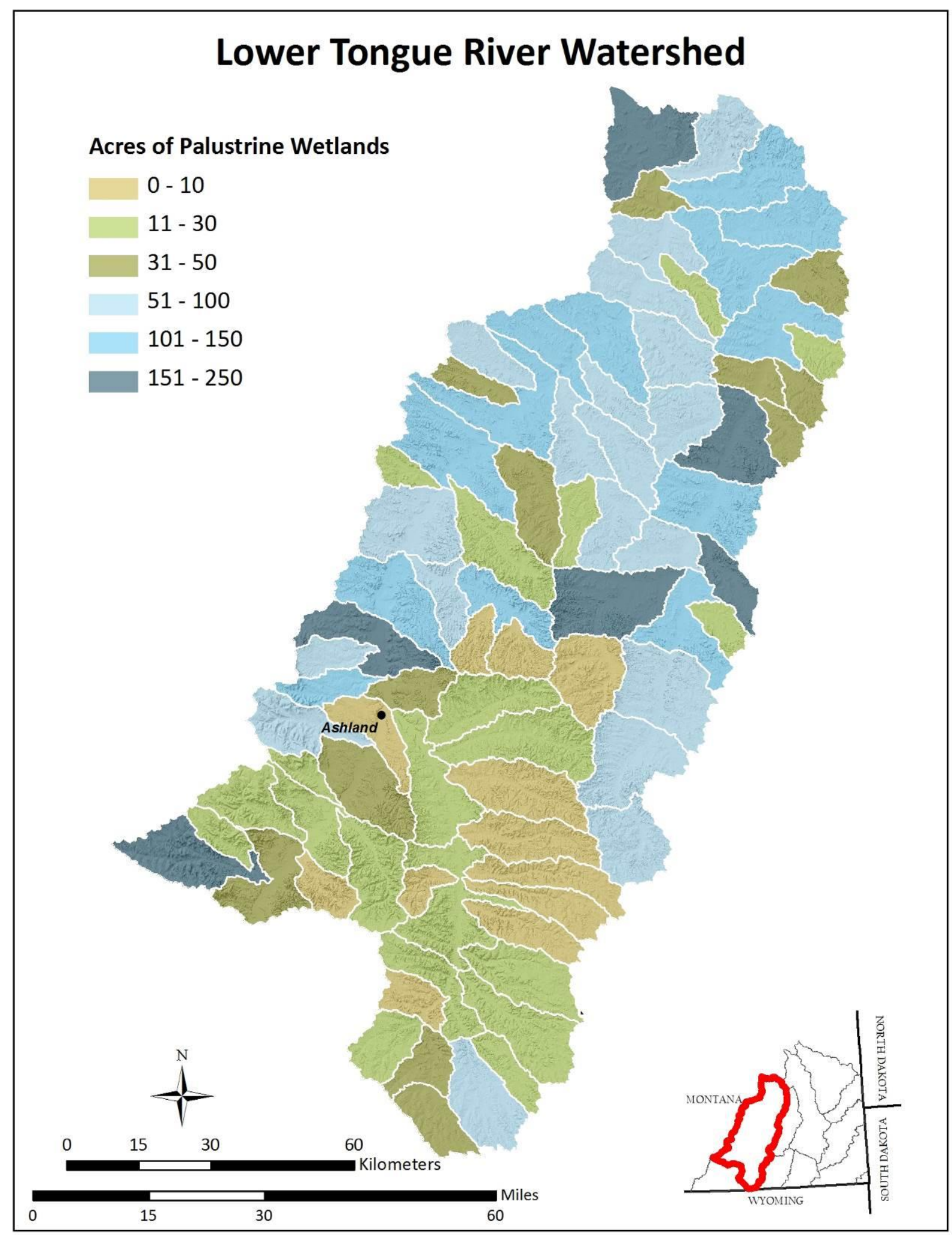

Figure 10. Acres of palustrine wetland by sixth code hydrologic unit in the Lower Tongue River watershed. 


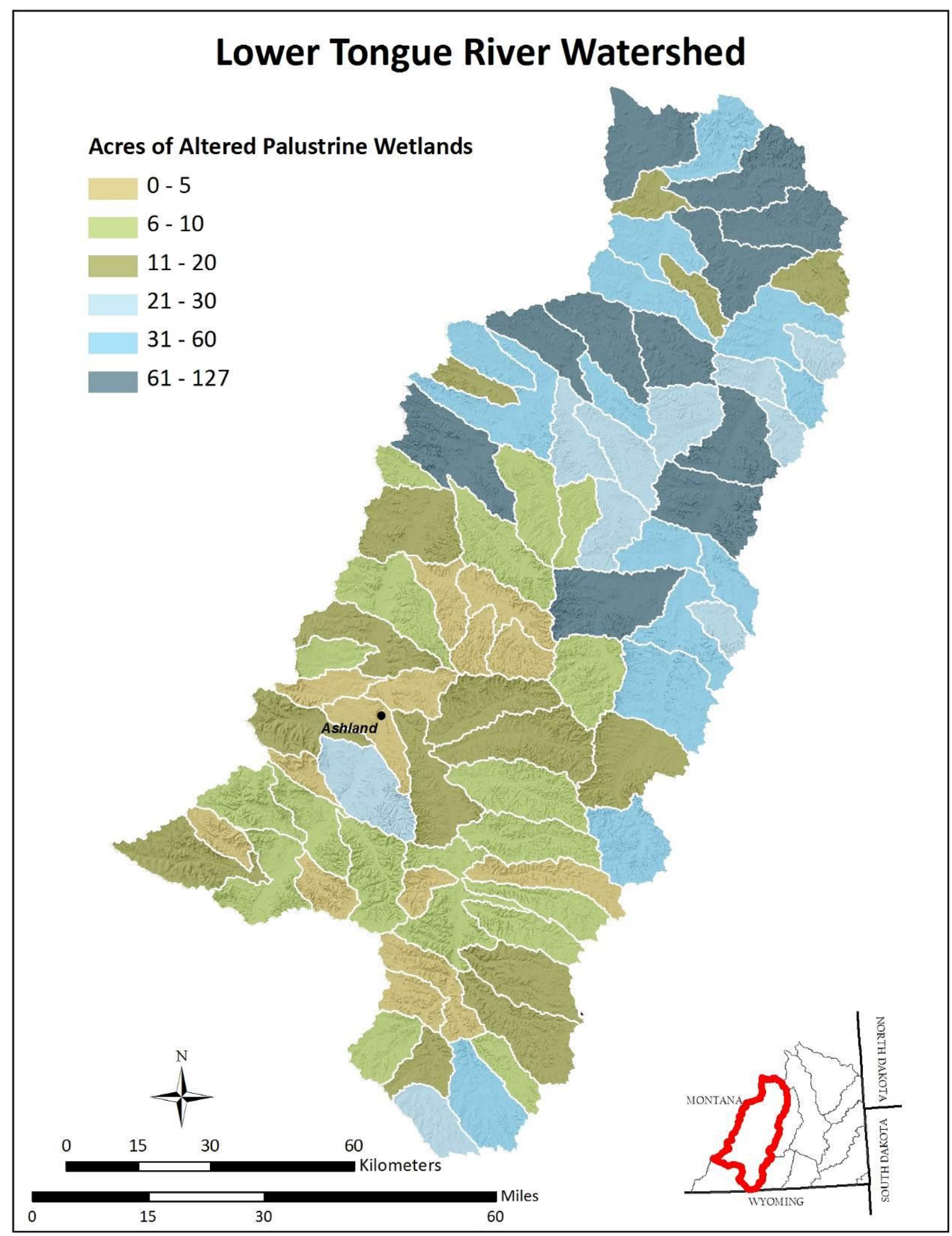

Figure 14. Acres of anthropogenically altered palustrine wetlands (i.e., ditched, drained, impounded, excavated, farmed) by sixth code hydrologic unit in the Lower Tongue River watershed. 


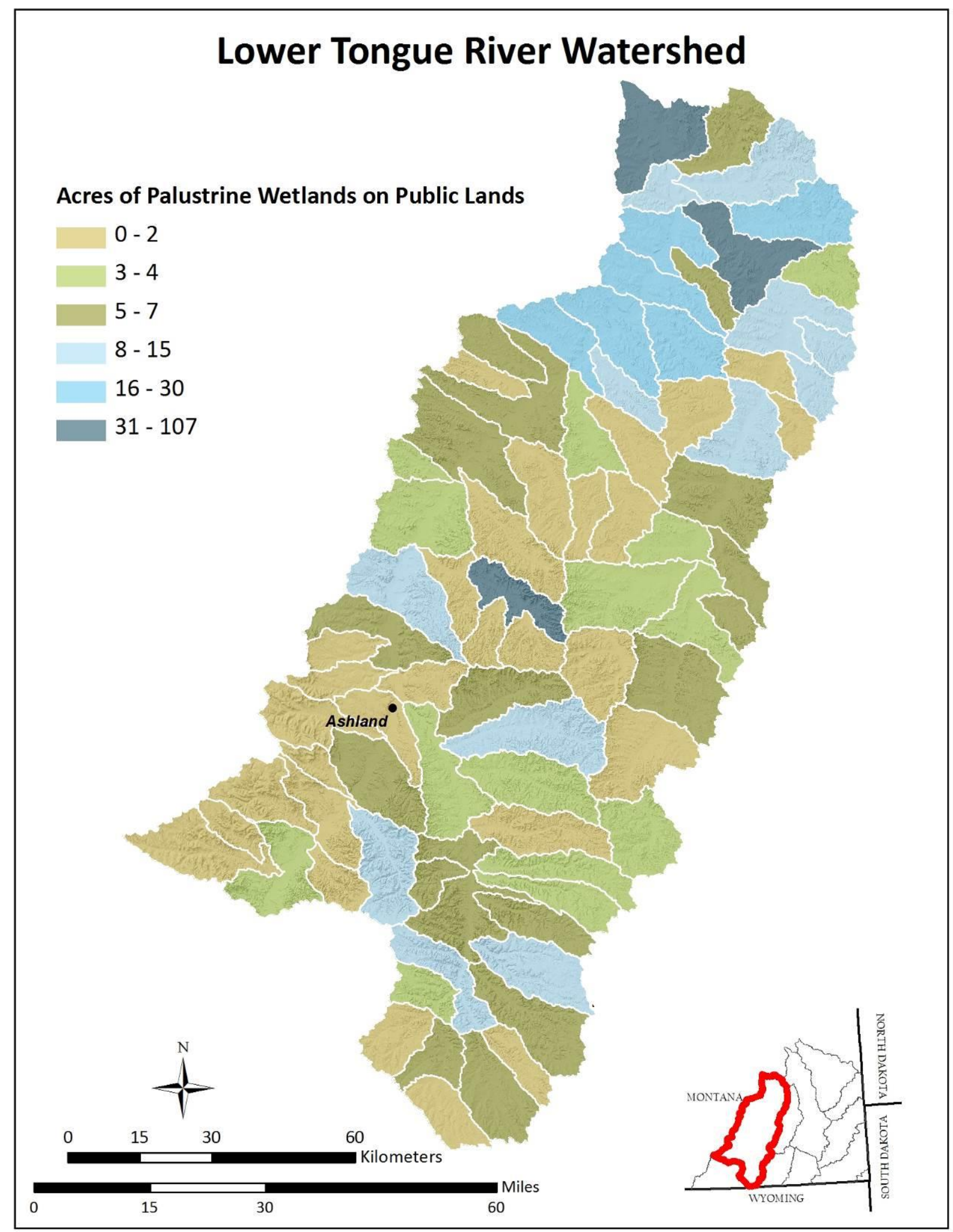

Figure 15. Acres of palustrine wetlands on publicly owned lands by sixth code hydrologic unit in the Lower Tongue River watershed. 


\section{Lower Tongue River Watershed}

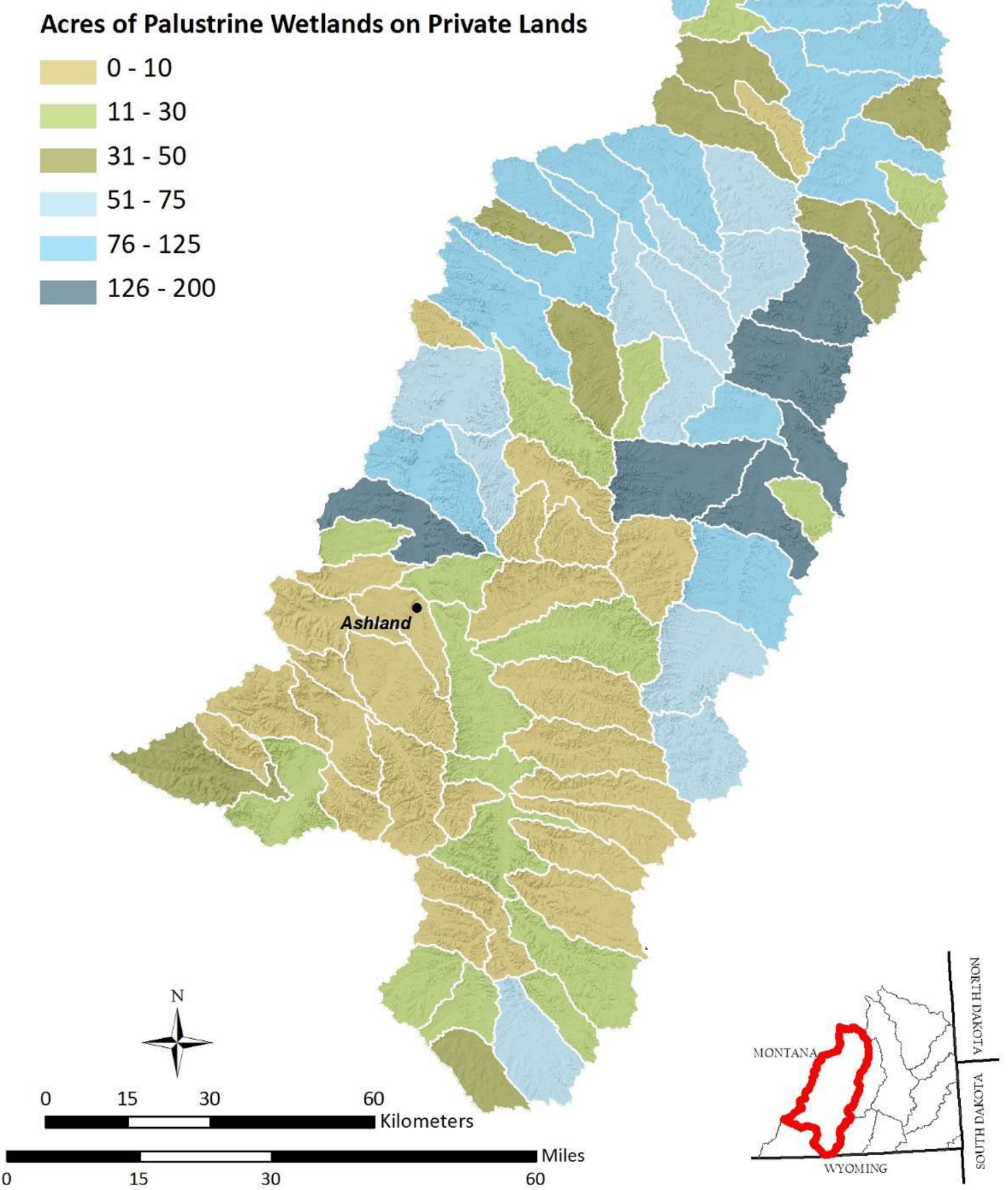

Figure 16. Acres of palustrine wetlands on privately owned lands by sixth code hydrologic unit in the Lower Tongue River watershed. 


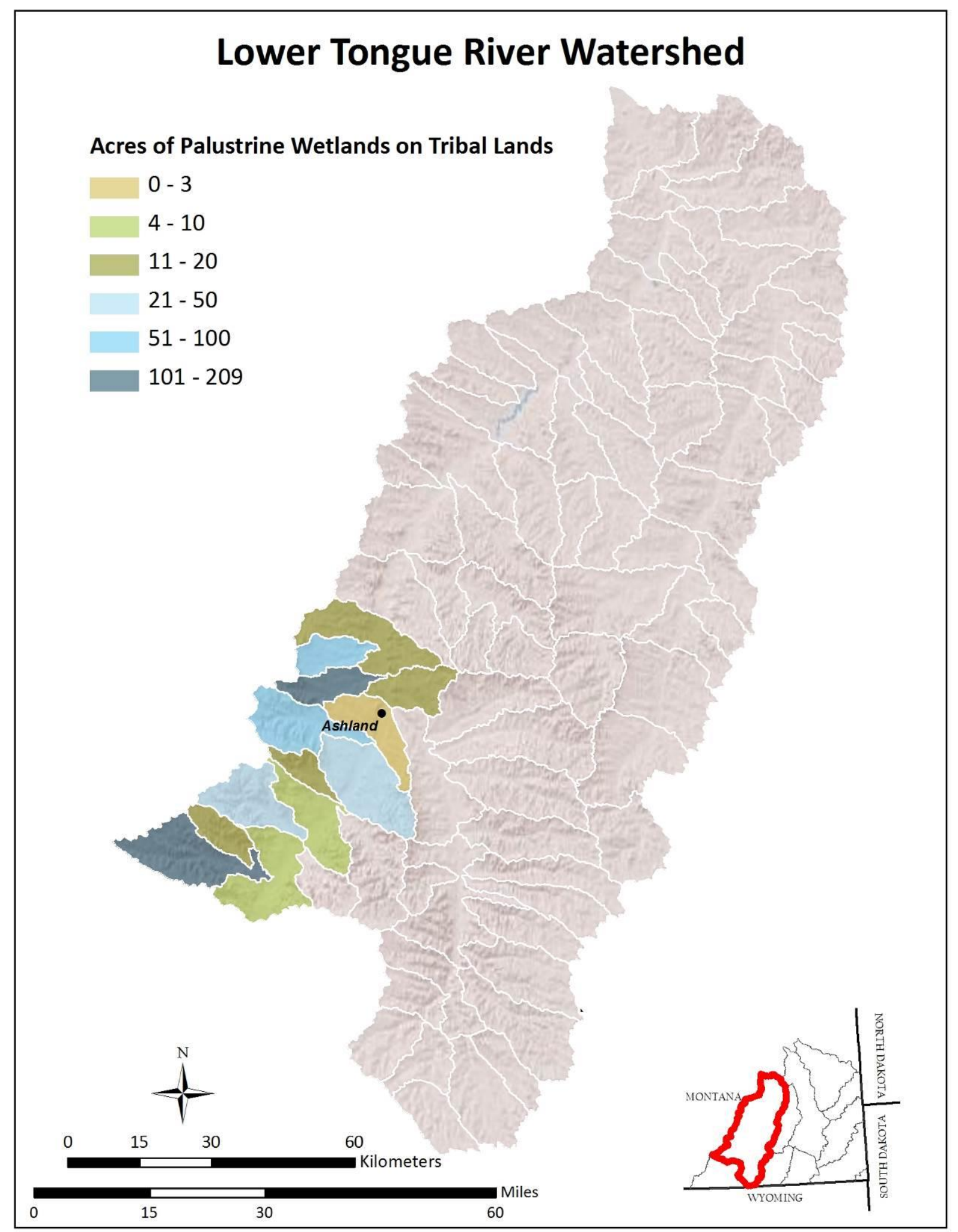

Figure 17. Acres of palustrine wetlands on Tribal lands by sixth code hydrologic unit in the Lower Tongue River watershed 


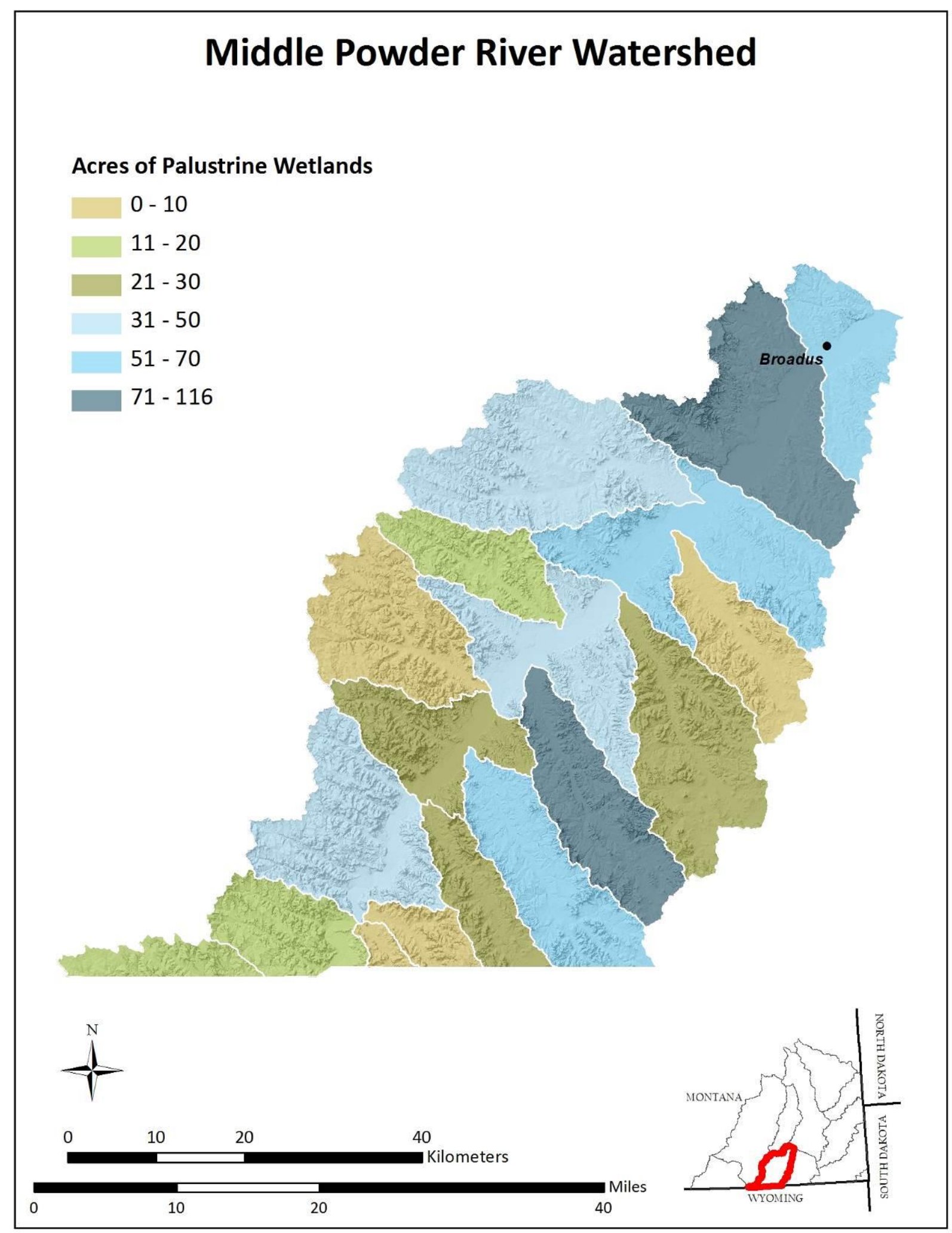

Figure 18. Acres of palustrine wetland by sixth code hydrologic unit in the Middle Powder River watershed. 


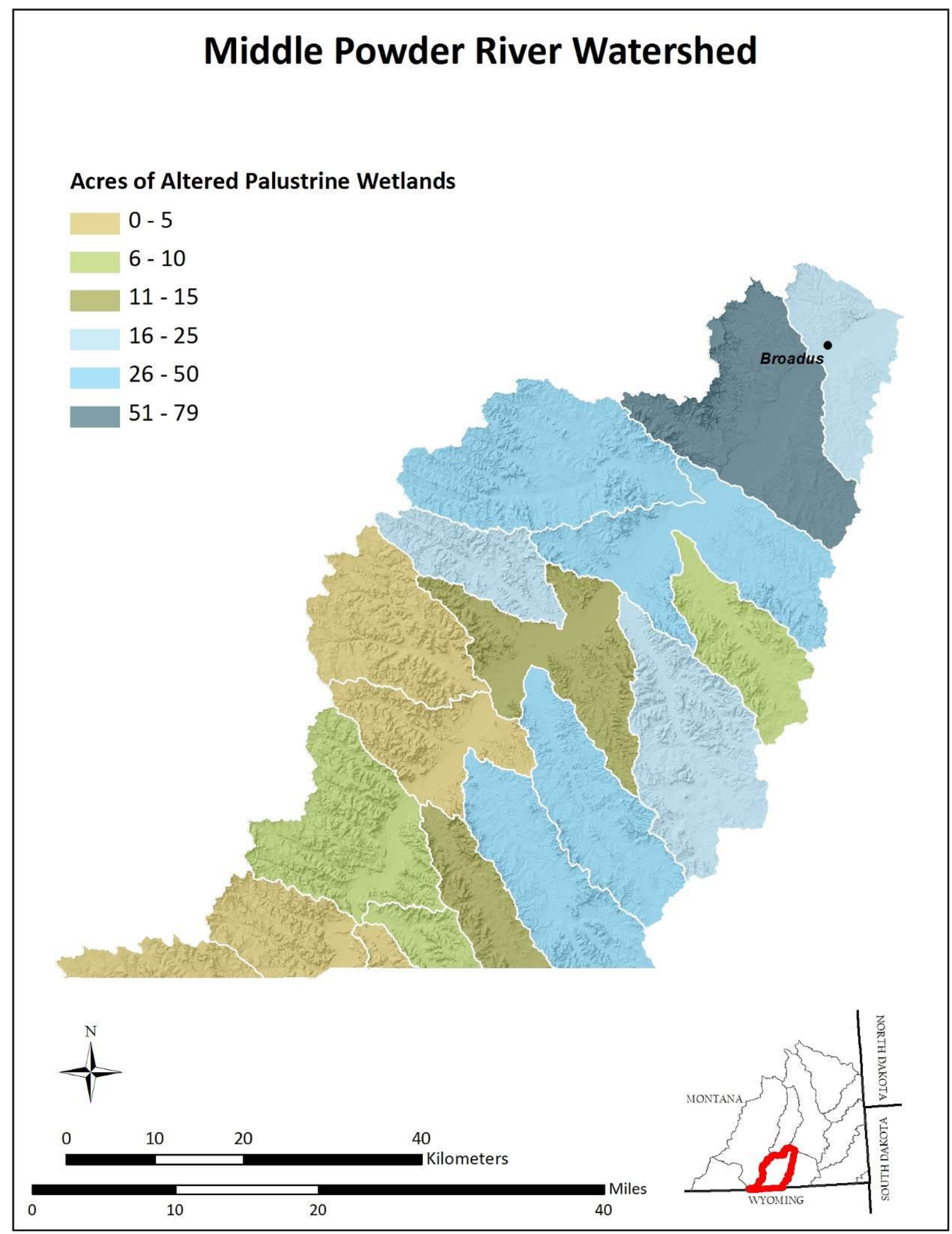

Figure 19. Acres of anthropogenically altered palustrine wetlands (i.e., ditched, drained, impounded, excavated, farmed) by sixth code hydrologic unit in the Middle Powder River watershed. 


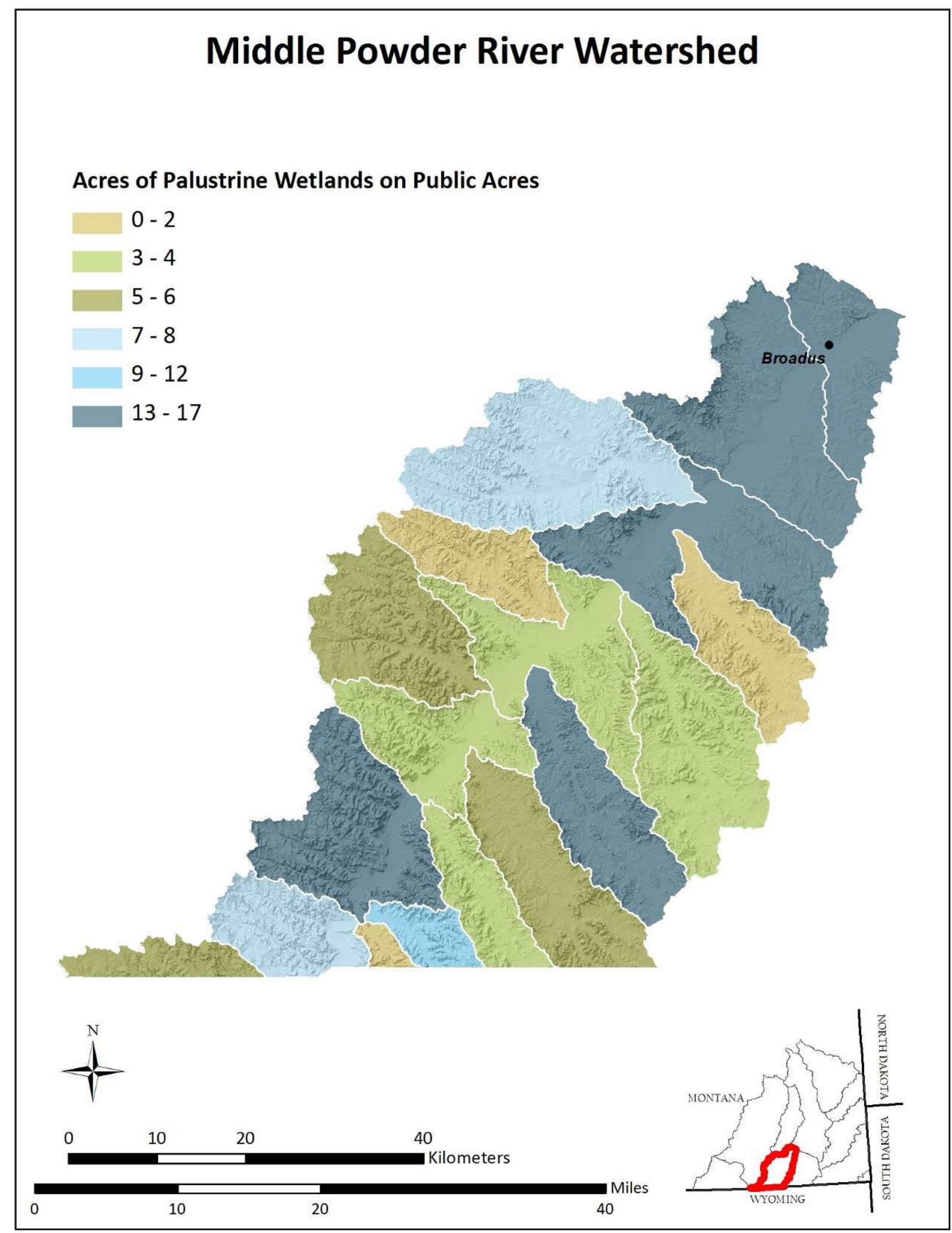

Figure 20. Acres of palustrine wetlands on publicly owned lands by sixth code hydrologic unit in the Middle Powder River watershed. 


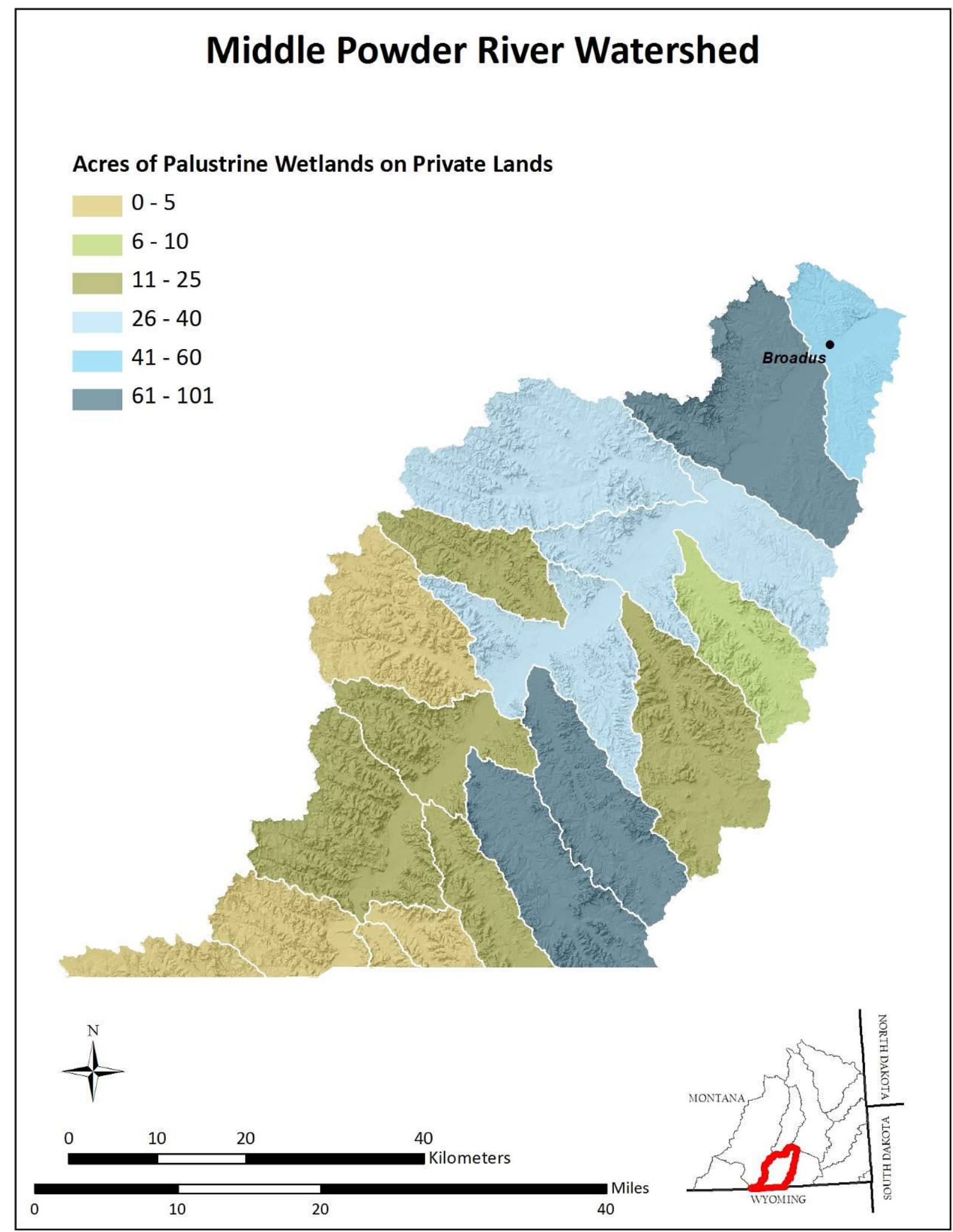

Figure 21. Acres of palustrine wetlands on privately owned lands by sixth code hydrologic unit in the Middle Powder River watershed. 


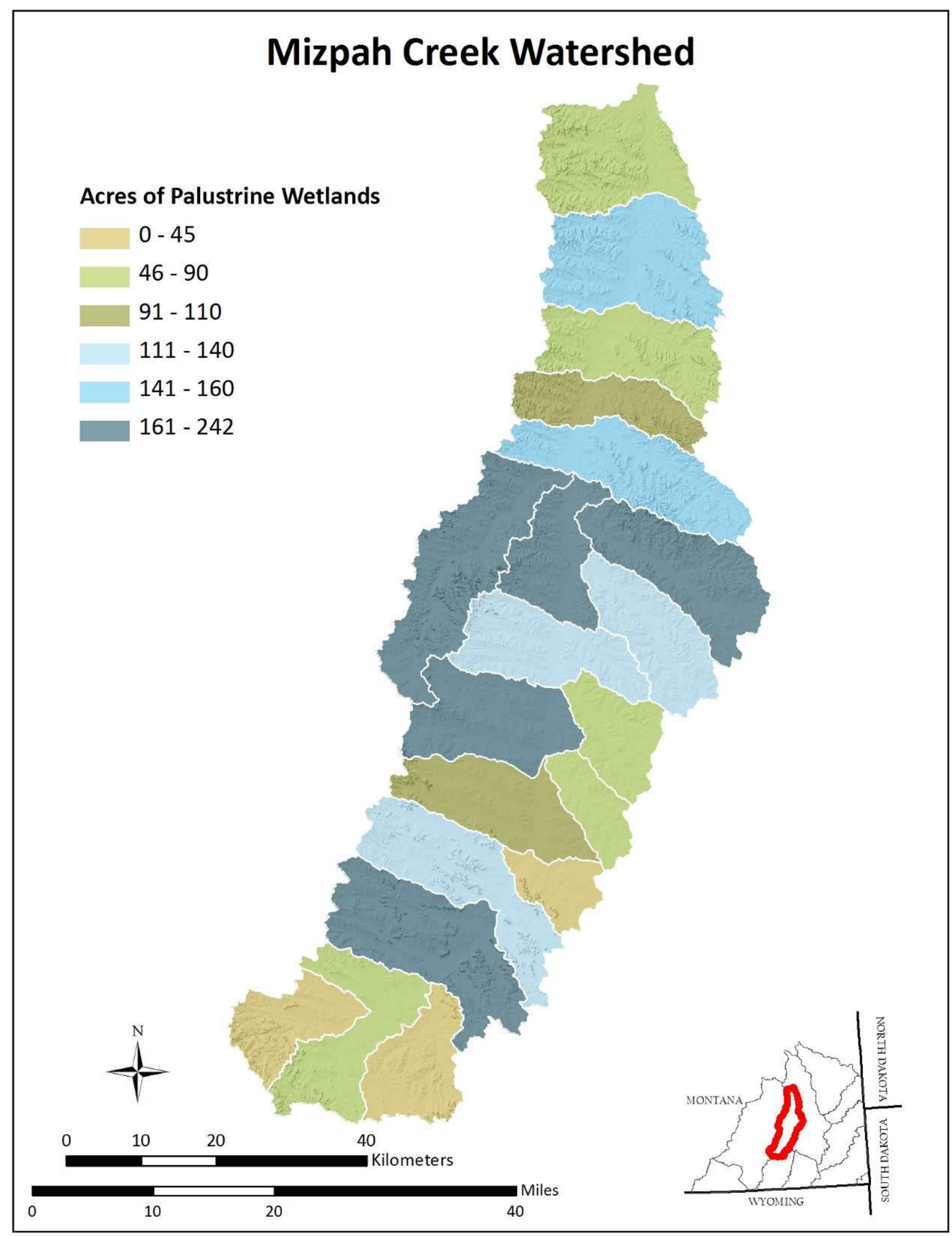

Figure 22. Acres of palustrine wetland by sixth code hydrologic unit in the Mizpah Creek watershed. 


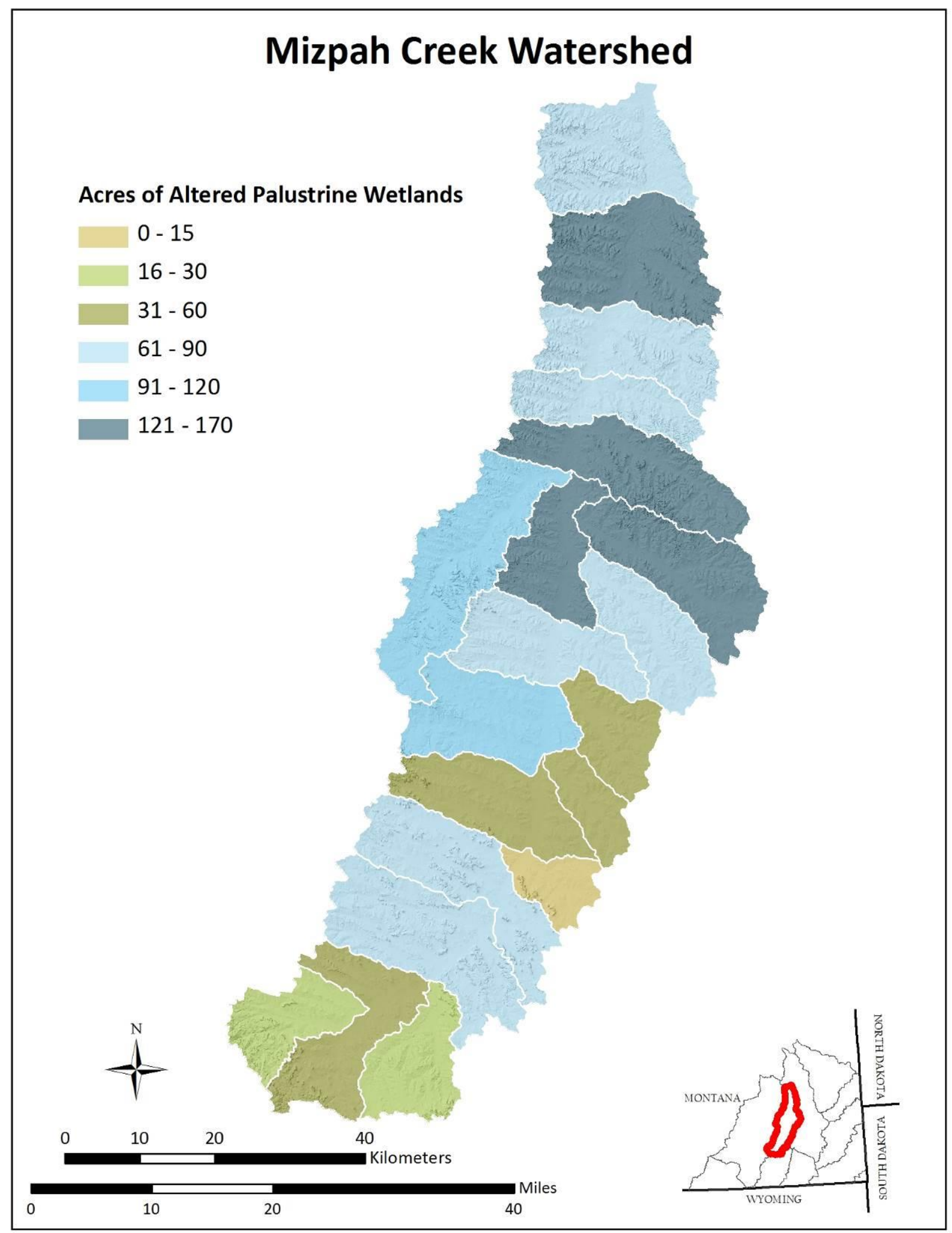

Figure 23. Acres of anthropogenically altered palustrine wetlands (i.e., ditched, drained, impounded, excavated, farmed) by sixth code hydrologic unit in the Mizpah Creek watershed. 


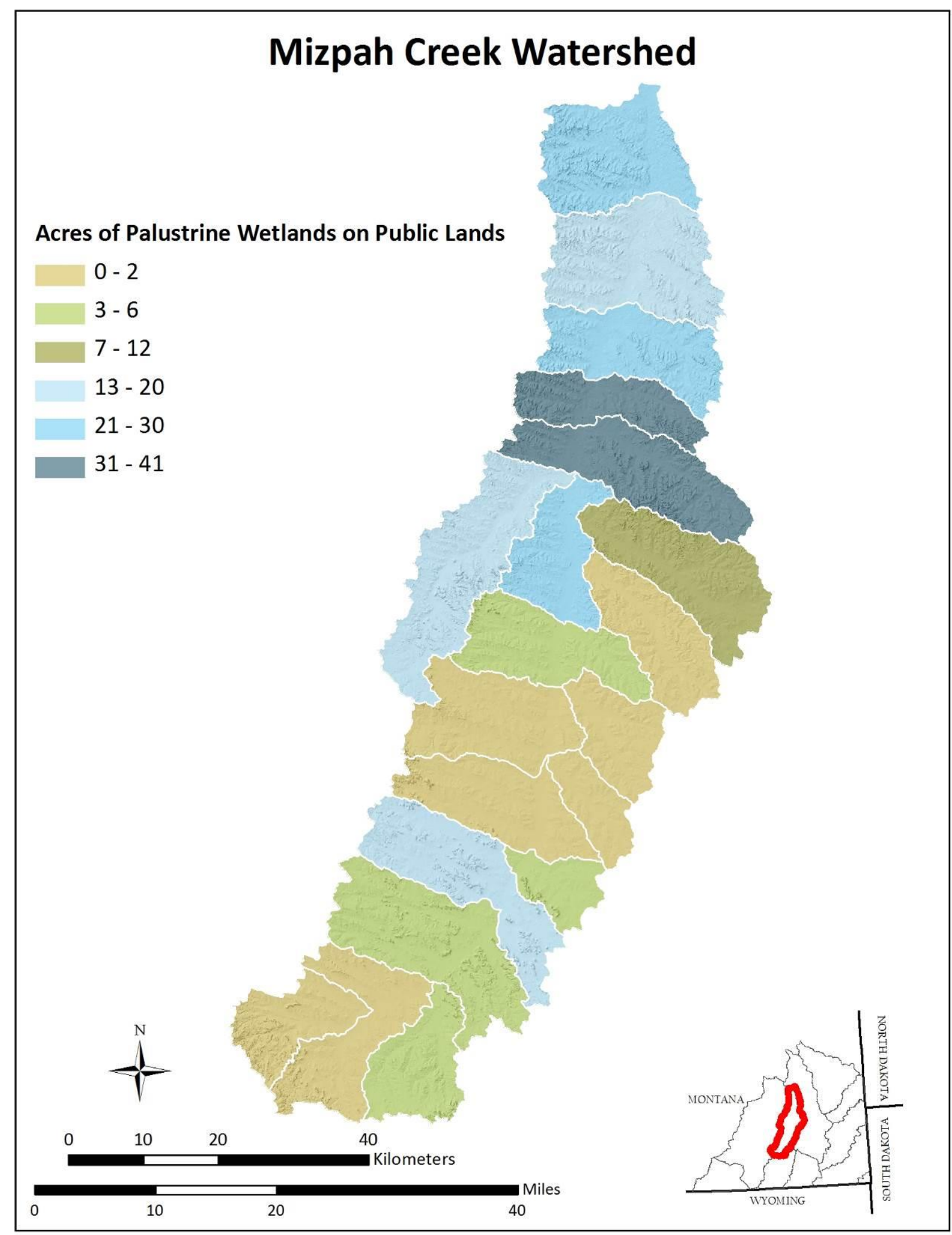

Figure 24. Acres of palustrine wetlands on publicly owned lands by sixth code hydrologic unit in the Mizpah Creek watershed. 


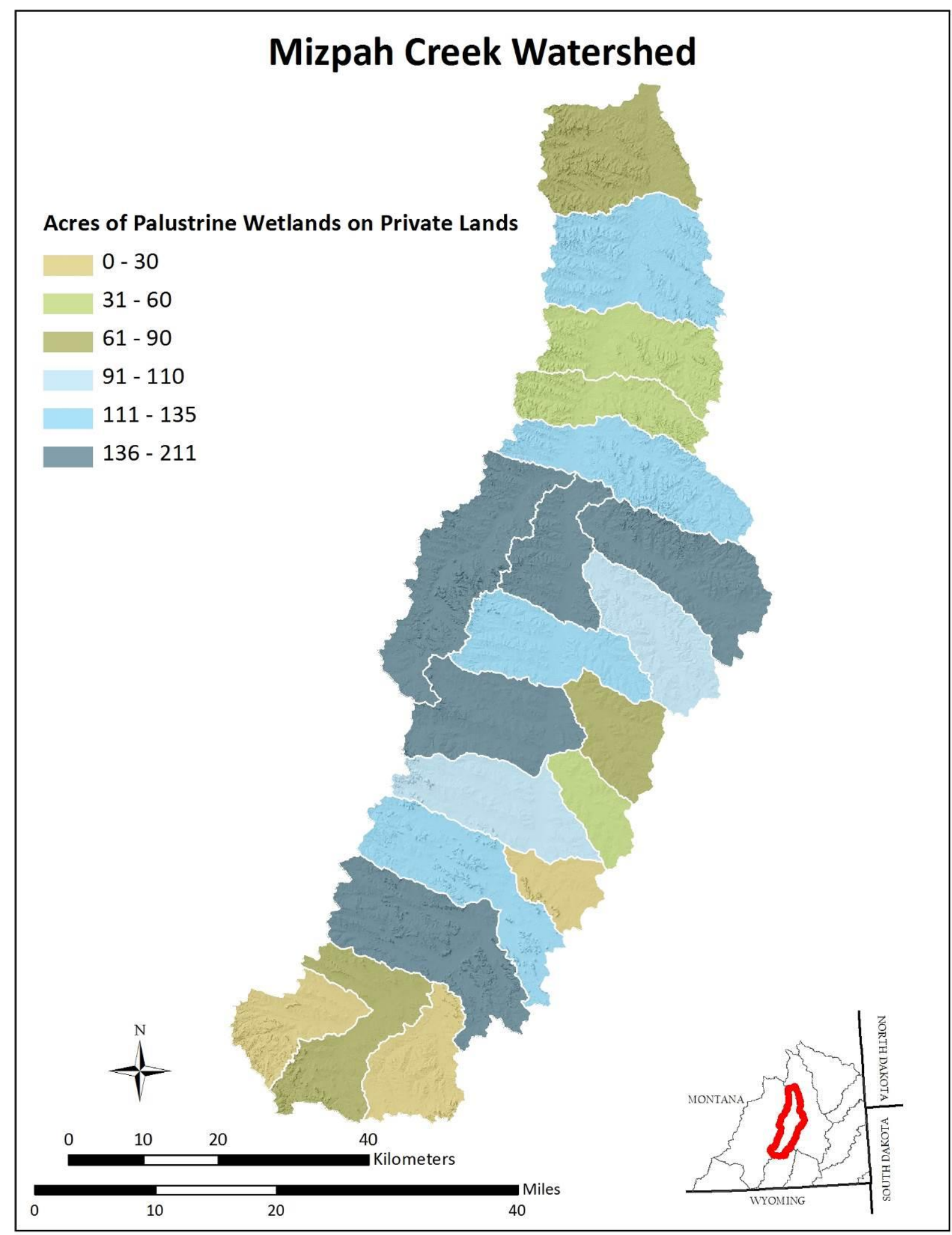

Figure 25. Acres of palustrine wetlands on privately owned lands by sixth code hydrologic unit in the Mizpah Creek watershed. 


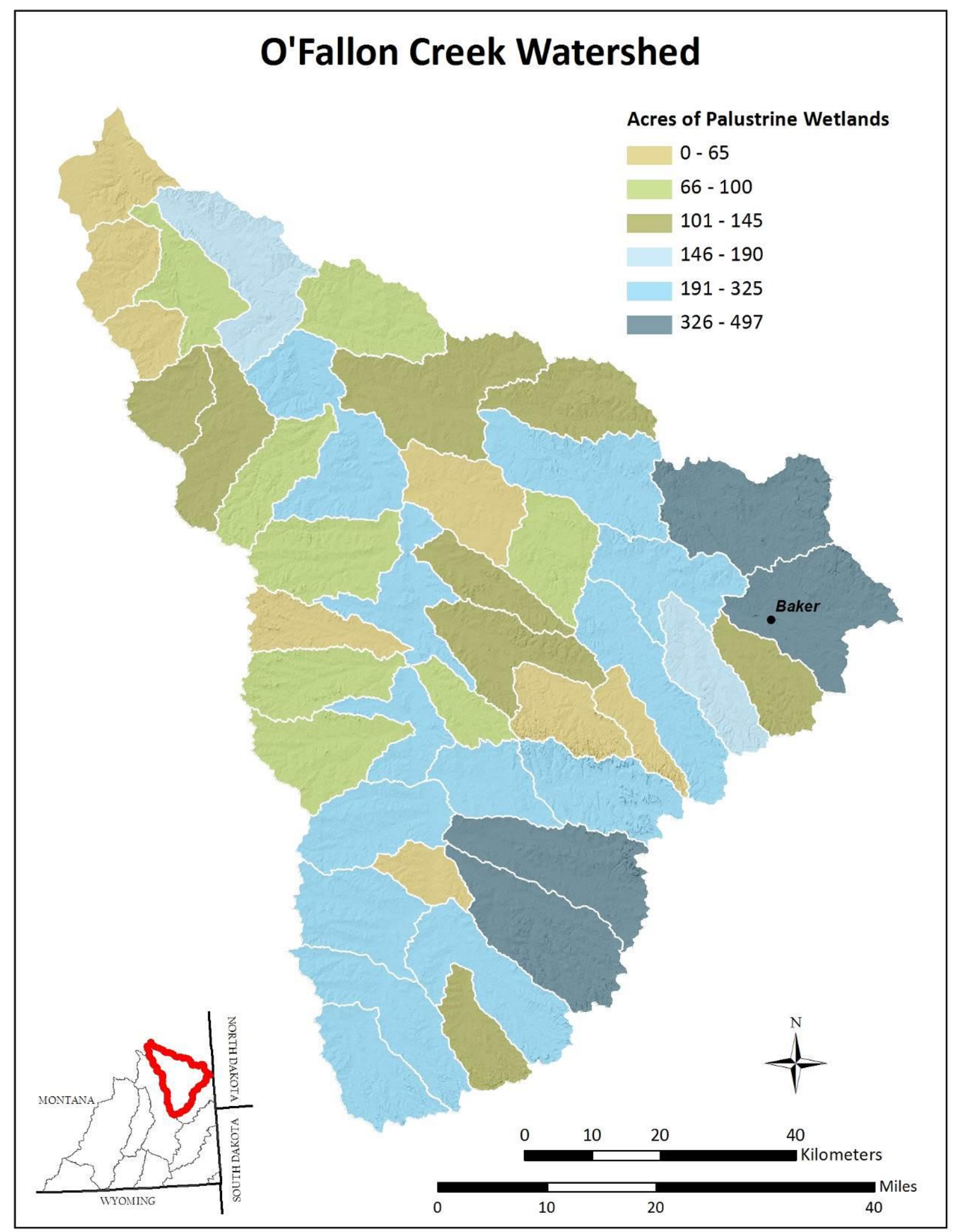

Figure 26. Acres of palustrine wetland by sixth code hydrologic unit in the O'Fallon Creek watershed. 


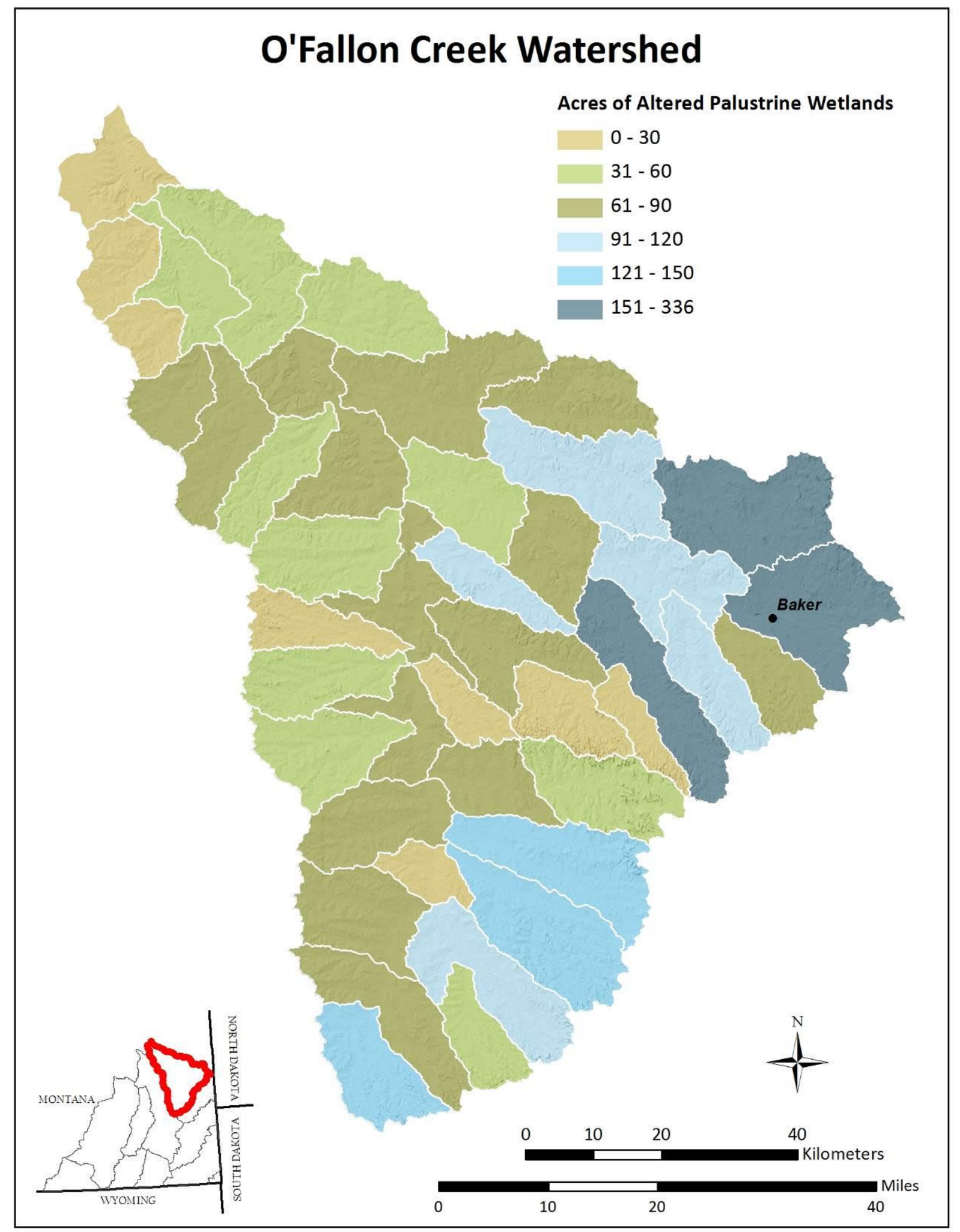

Figure 27. Acres of anthropogenically altered palustrine wetlands (i.e., ditched, drained, impounded, excavated, farmed) by sixth code hydrologic unit in the O'Fallon Creek watershed. 


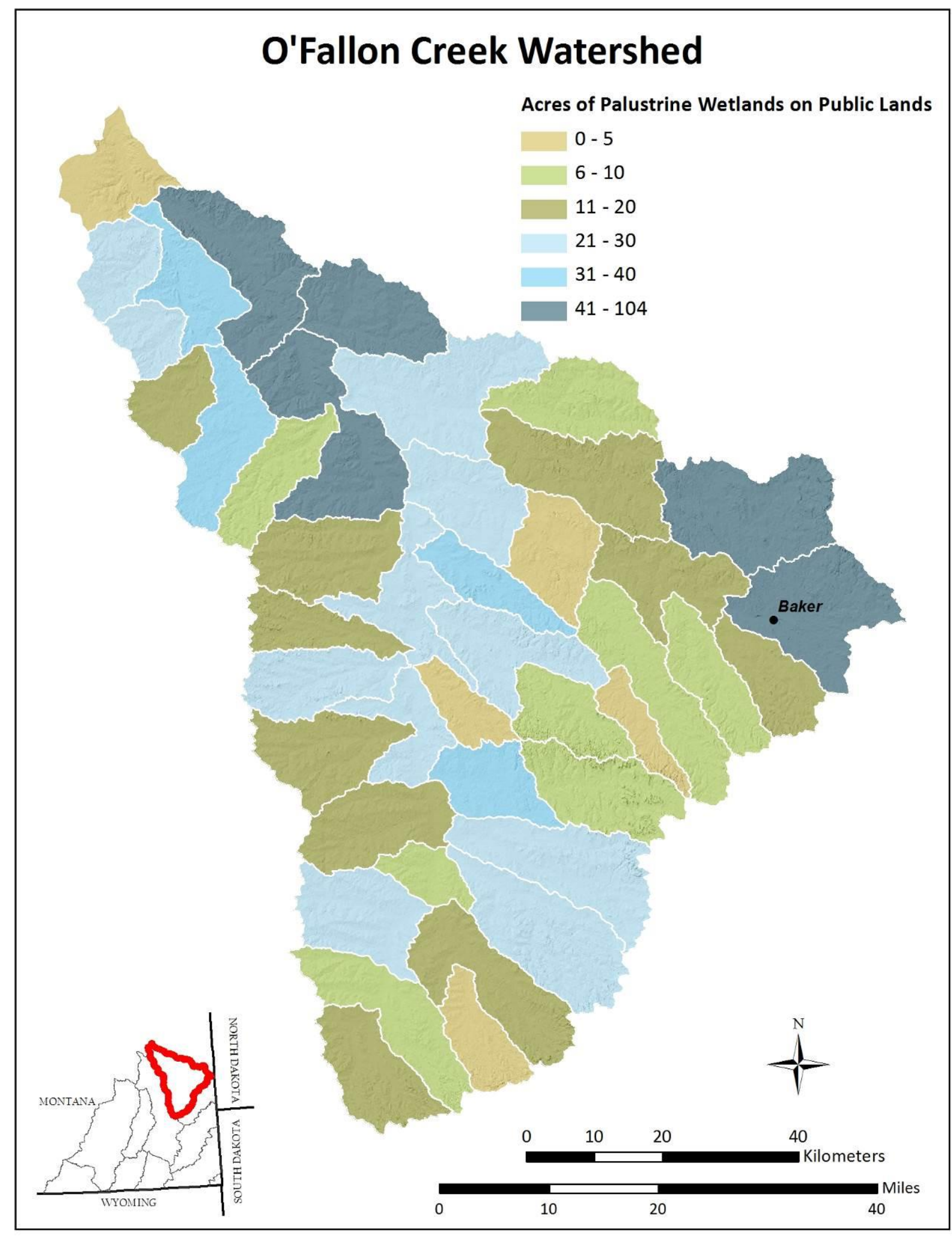

Figure 28. Acres of palustrine wetlands on publicly owned lands by sixth code hydrologic unit in the O'Fallon Creek watershed. 


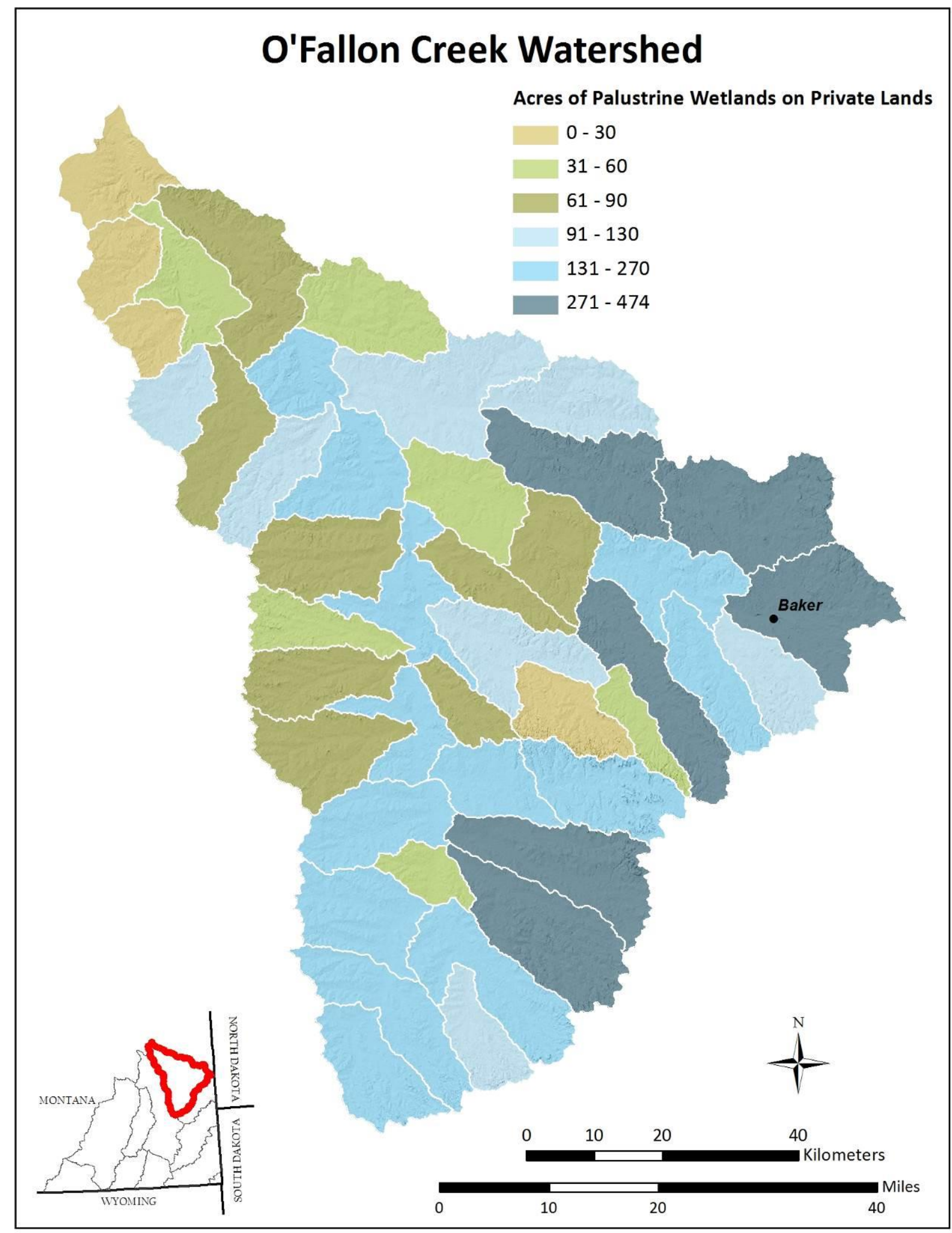

Figure 29. Acres of palustrine wetlands on privately owned lands by sixth code hydrologic unit in the O'Fallon Creek watershed. 


\section{Upper Little Missouri River Watershed}

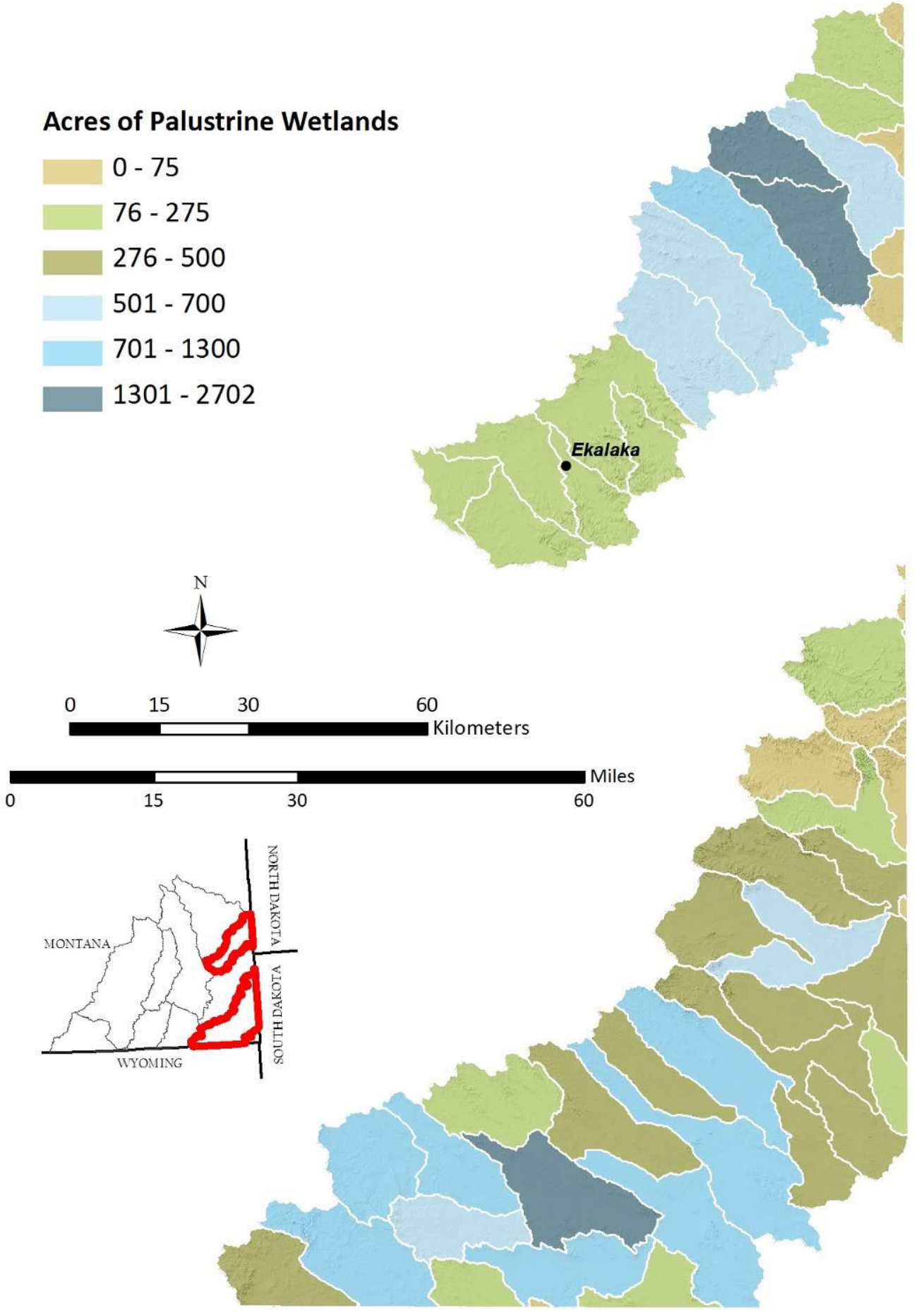

Figure 30. Acres of palustrine wetland by sixth code hydrologic unit in the Upper Little Missouri River watershed. 


\section{Upper Little Missouri River Watershed}

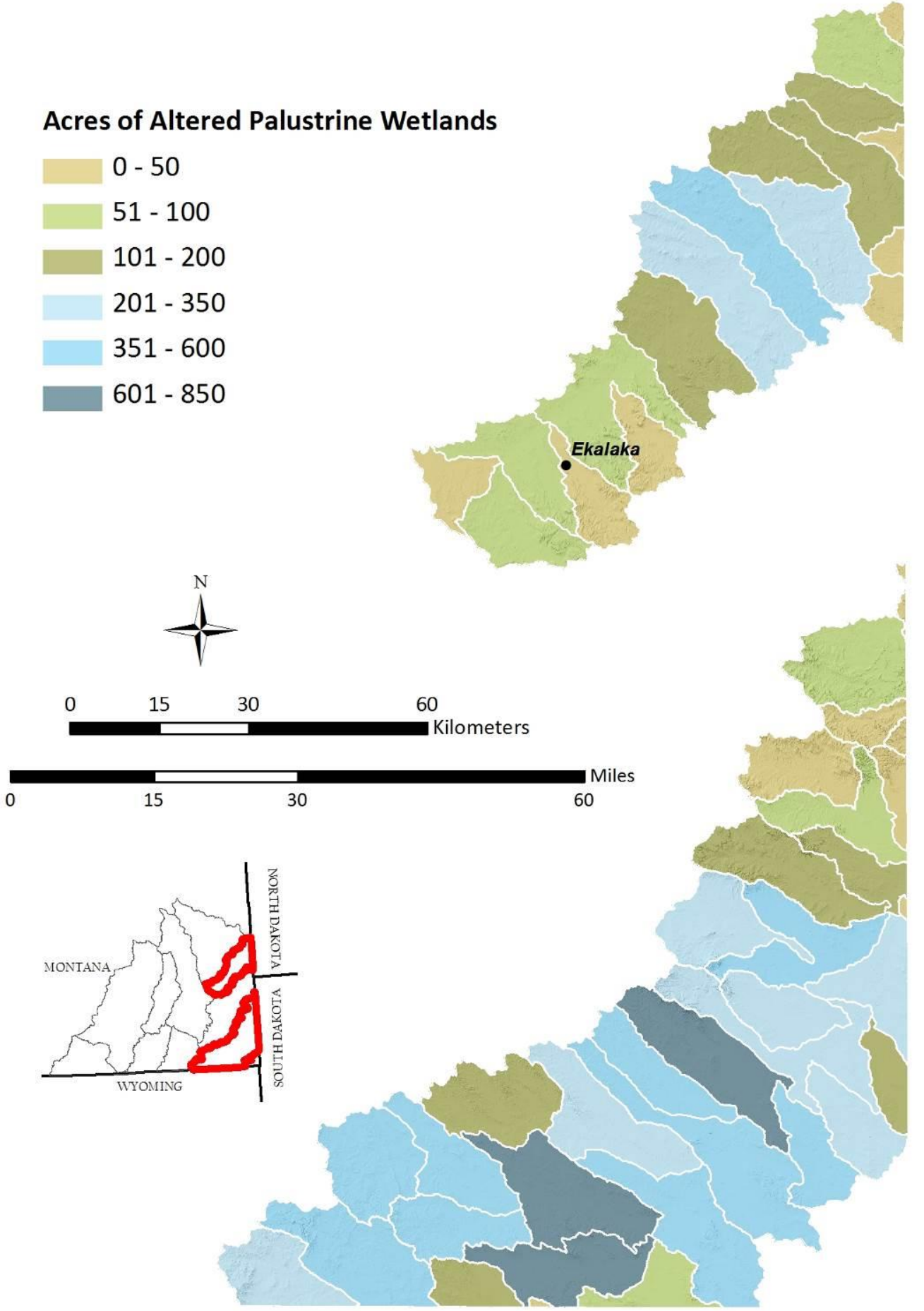

Figure 31. Acres of anthropogenically altered palustrine wetlands (i.e., ditched, drained, impounded, excavated, farmed) by sixth code hydrologic unit in the Upper Little Missouri River watershed. 


\section{Upper Little Missouri River Watershed}

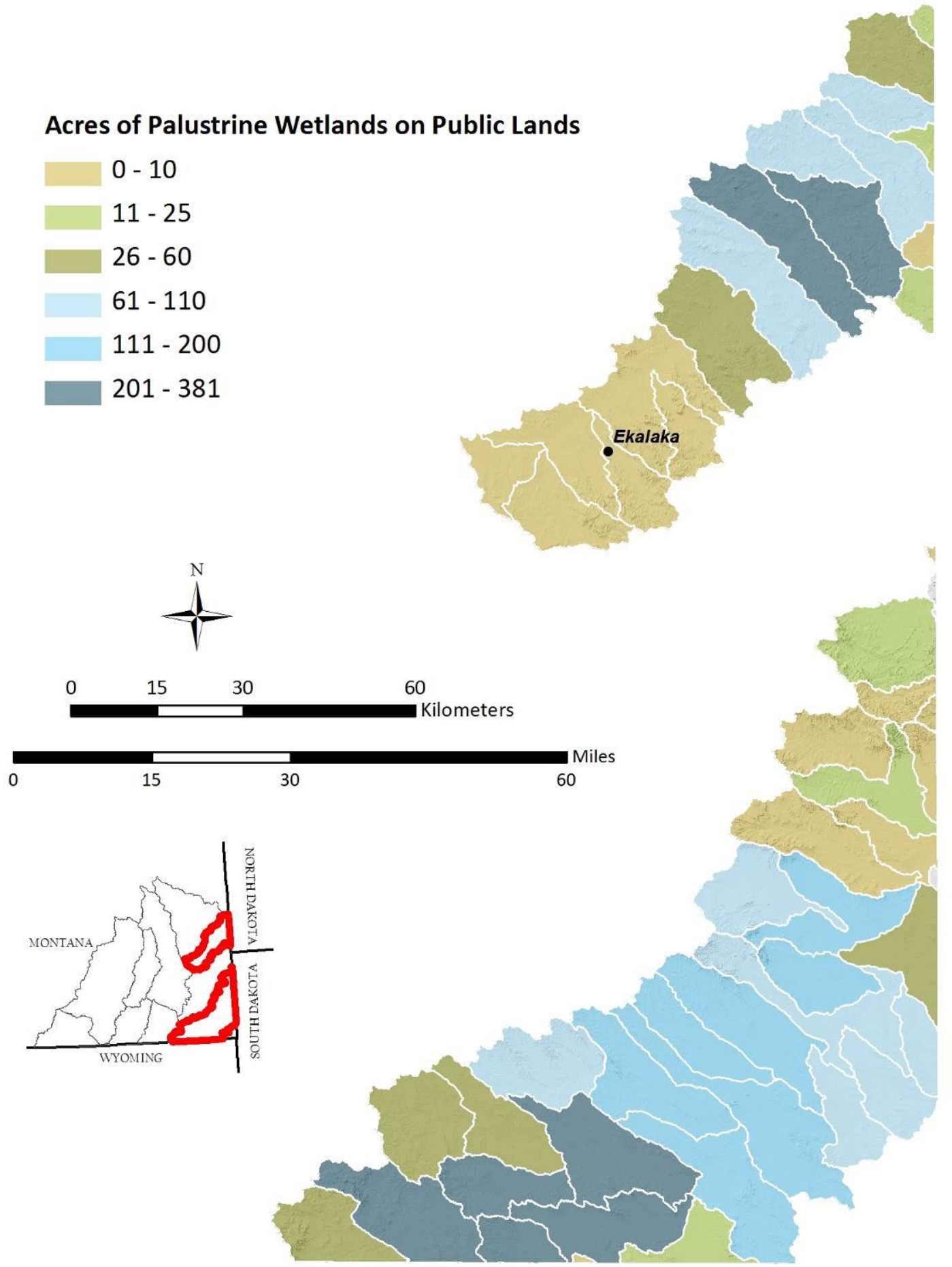

Figure 32. Acres of palustrine wetlands on publicly owned lands by sixth code hydrologic unit in the Upper Little Missouri watershed. 


\section{Upper Little Missouri River Watershed}

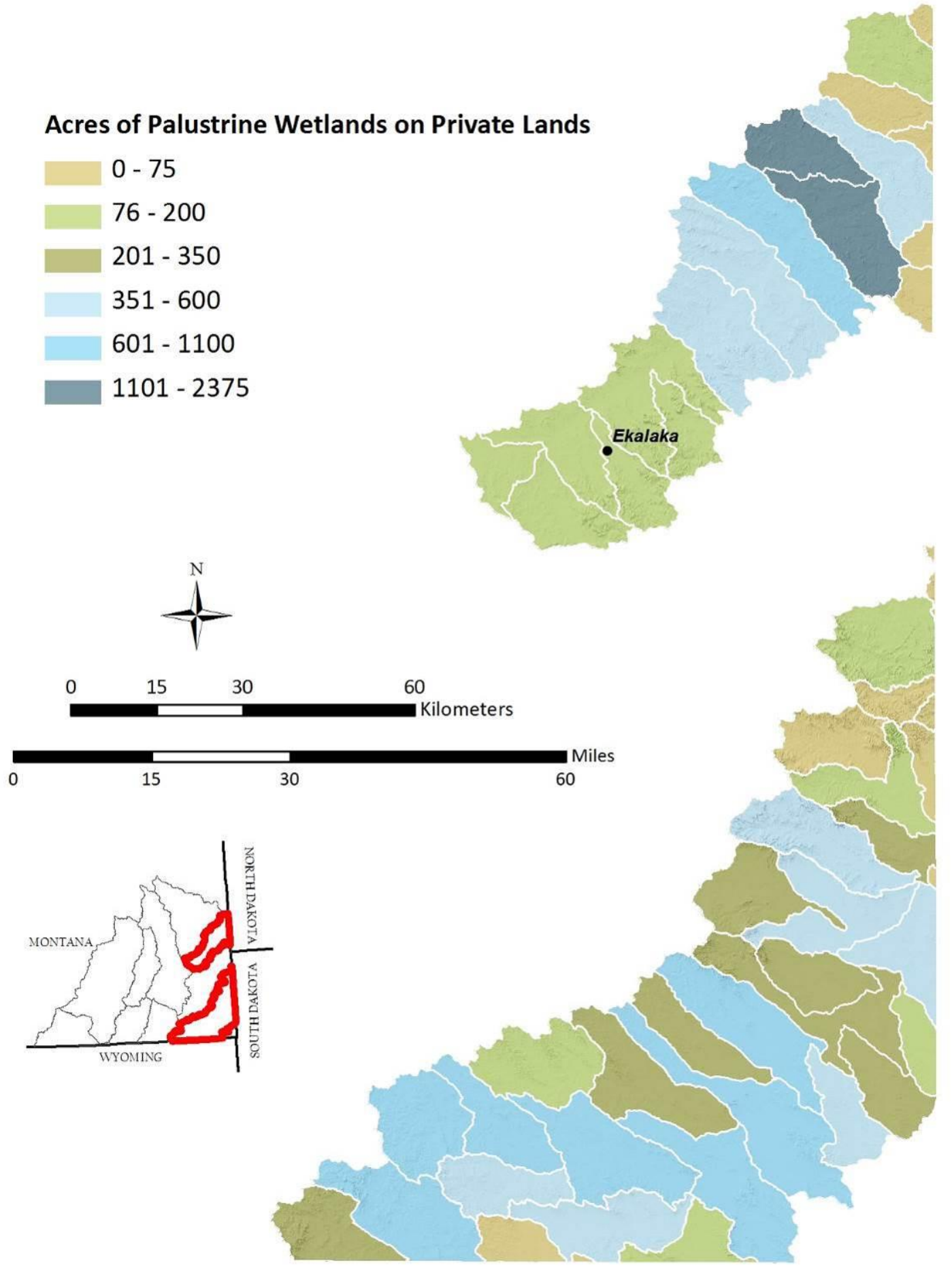

Figure 33. Acres of palustrine wetlands on privately owned lands by sixth code hydrologic unit in the Upper Little Missouri watershed. 


\section{Upper Tongue River Watershed}

\section{Acres of Palustrine Wetlands}

$0-5$

$6-20$

$21-50$

$51-75$

$76-150$

$151-279$
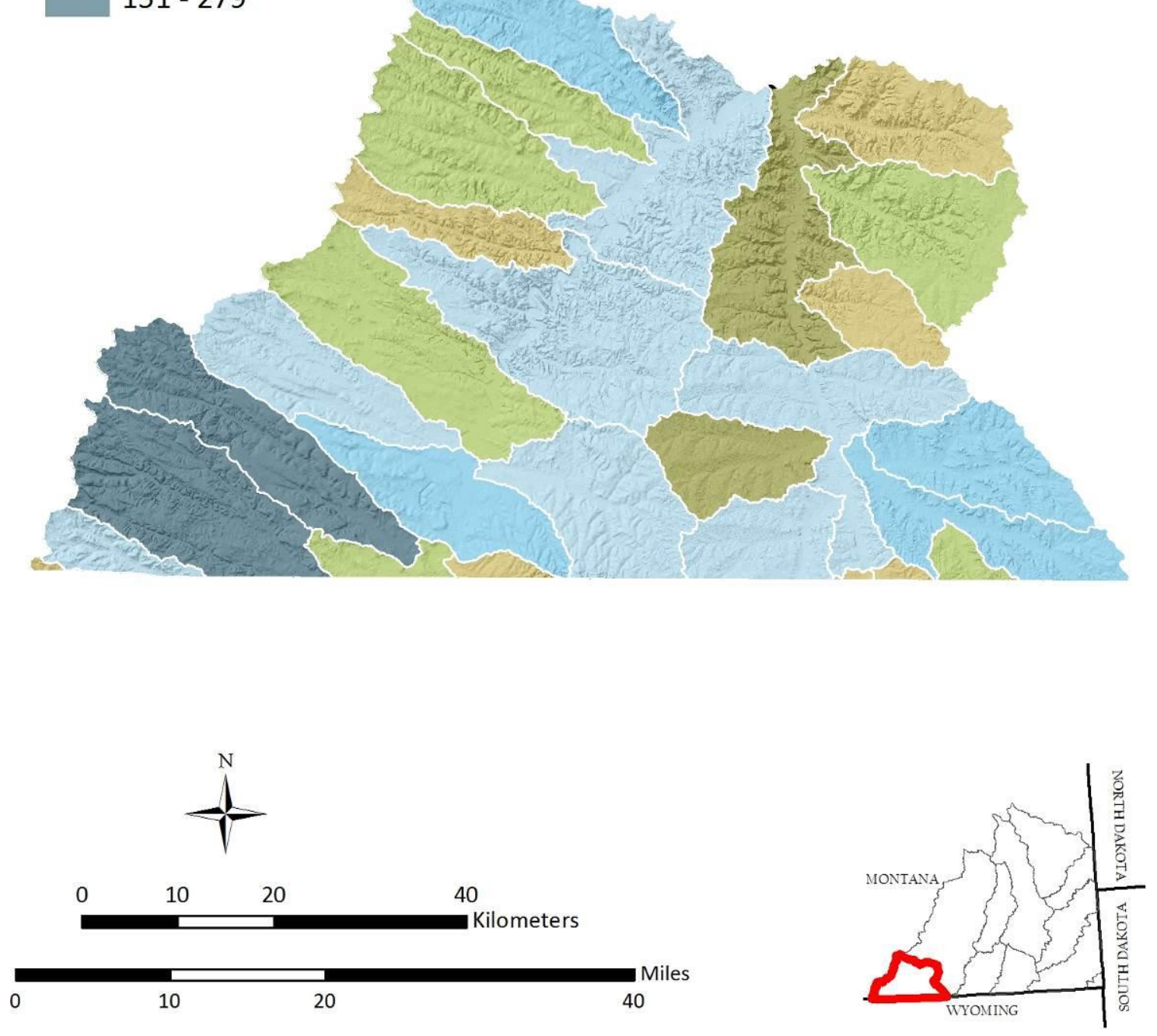

Figure 34. Acres of palustrine wetland by sixth code hydrologic unit in the Upper Tongue River watershed. 


\section{Upper Tongue River Watershed}

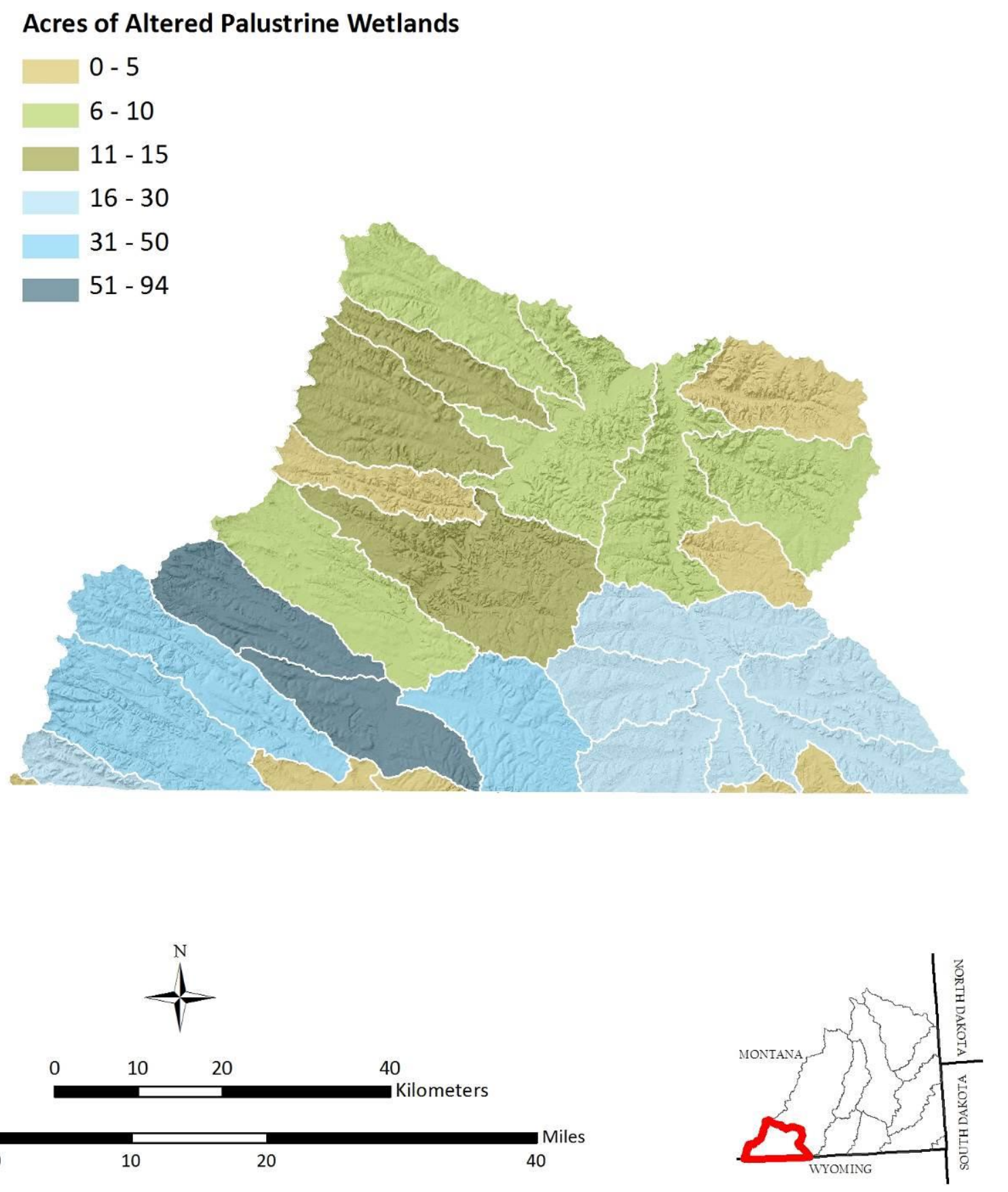

Figure 35. Acres of anthropogenically altered palustrine wetlands (i.e., ditched, drained, impounded, excavated, farmed) by sixth code hydrologic unit in the Upper Tongue River watershed. 


\section{Upper Tongue River Watershed}

\section{Acres of Palustrine Wetlands on Public Lands}

$0-2$

$3-4$

$5-6$

$7-8$

$9-20$

$21-33$
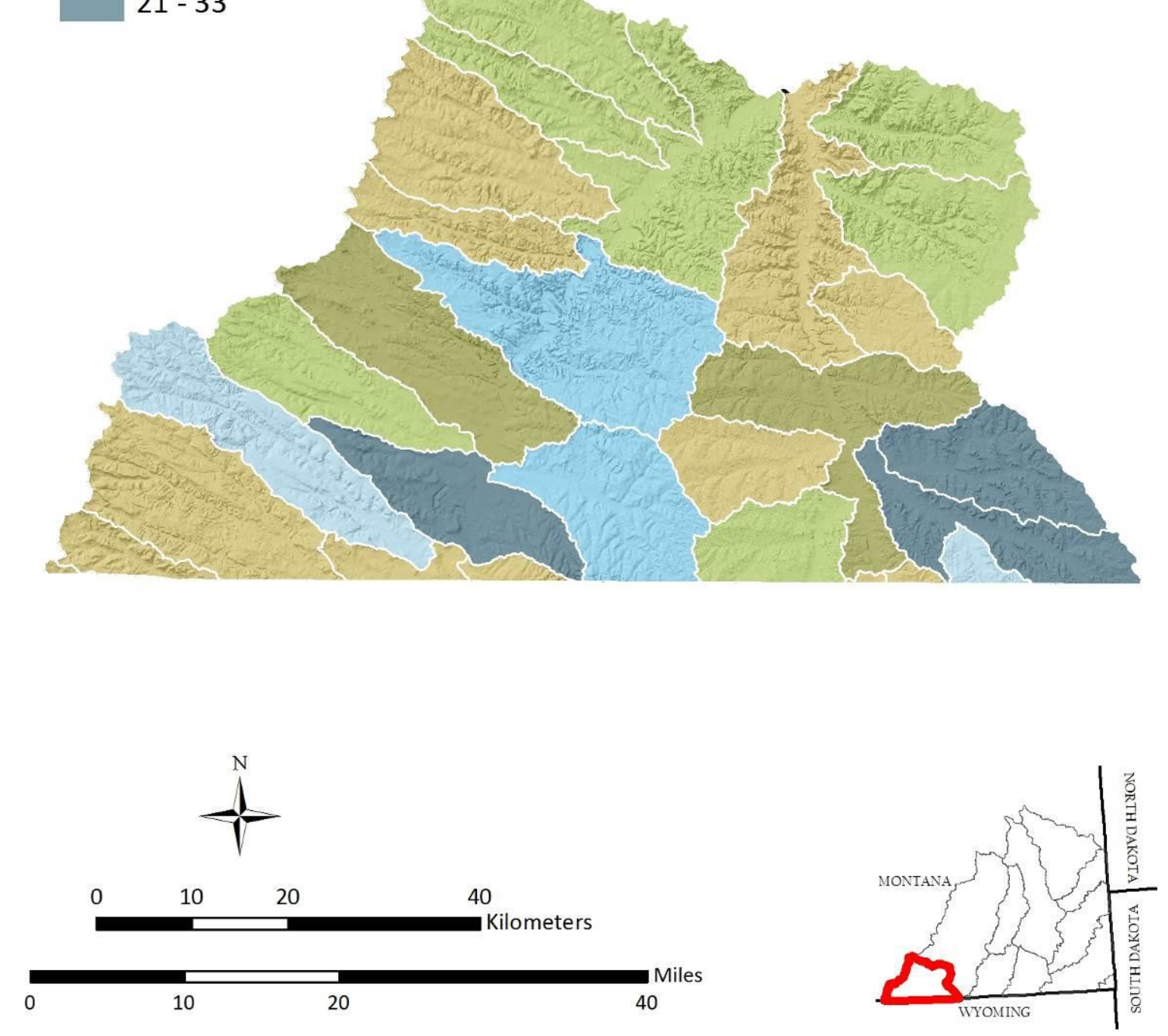

Figure 36. Acres of palustrine wetlands on publicly owned lands by sixth code hydrologic unit in the Upper Tongue River watershed. 


\section{Upper Tongue River Watershed}

Acres of Palustrine Wetlands on Private Lands

$0-5$

$6-10$

$11-20$

$21-60$

$61-140$

$141-255$
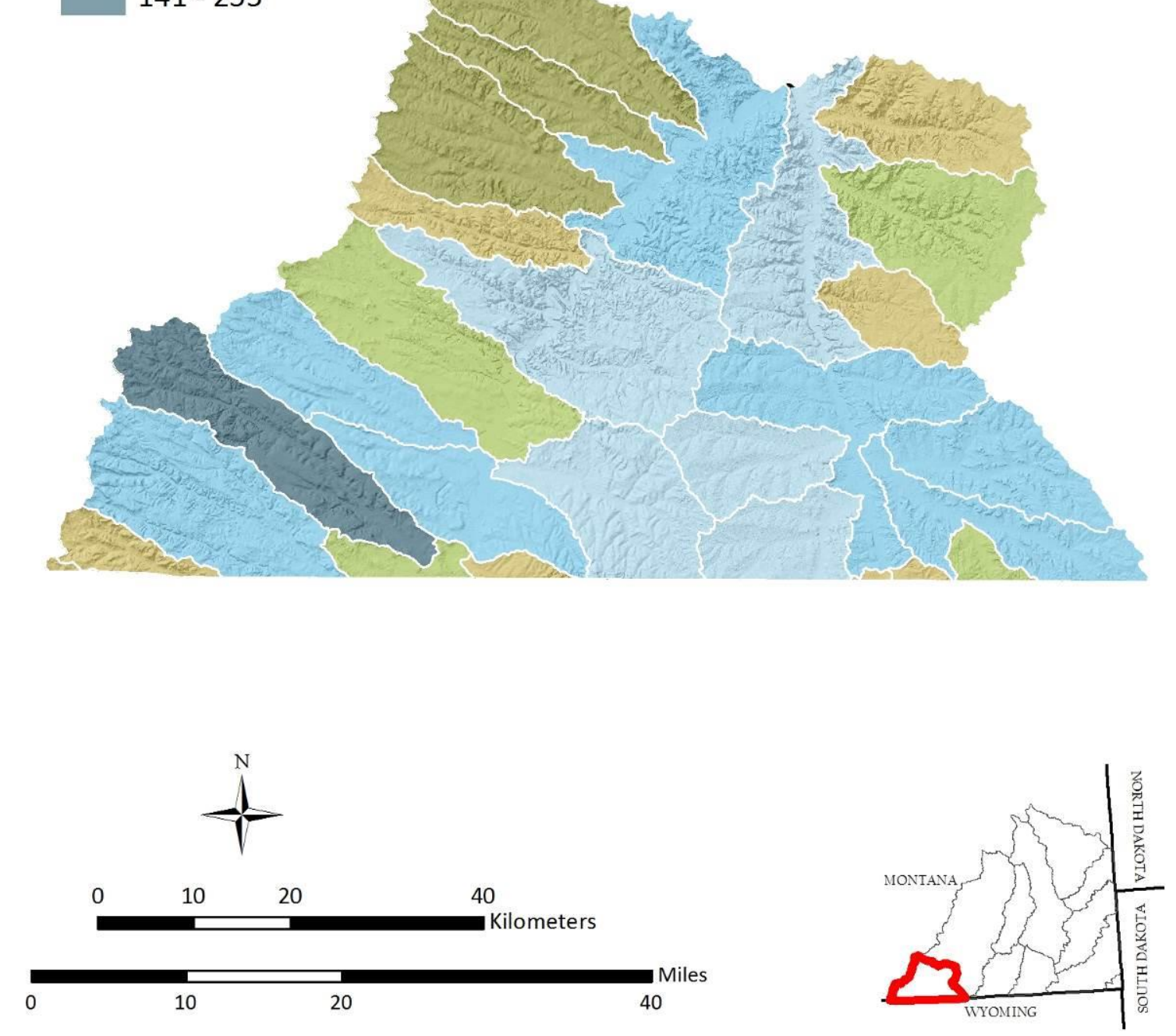

Figure 37. Acres of palustrine wetlands on privately owned lands by sixth code hydrologic unit in the Upper Tongue River watershed 


\section{Upper Tongue River Watershed}

\section{Acres of Palustrine Wetlands on Tribal Lands}

$0-10$

$11-30$

$31-50$

$51-90$

$91-110$

$111-136$
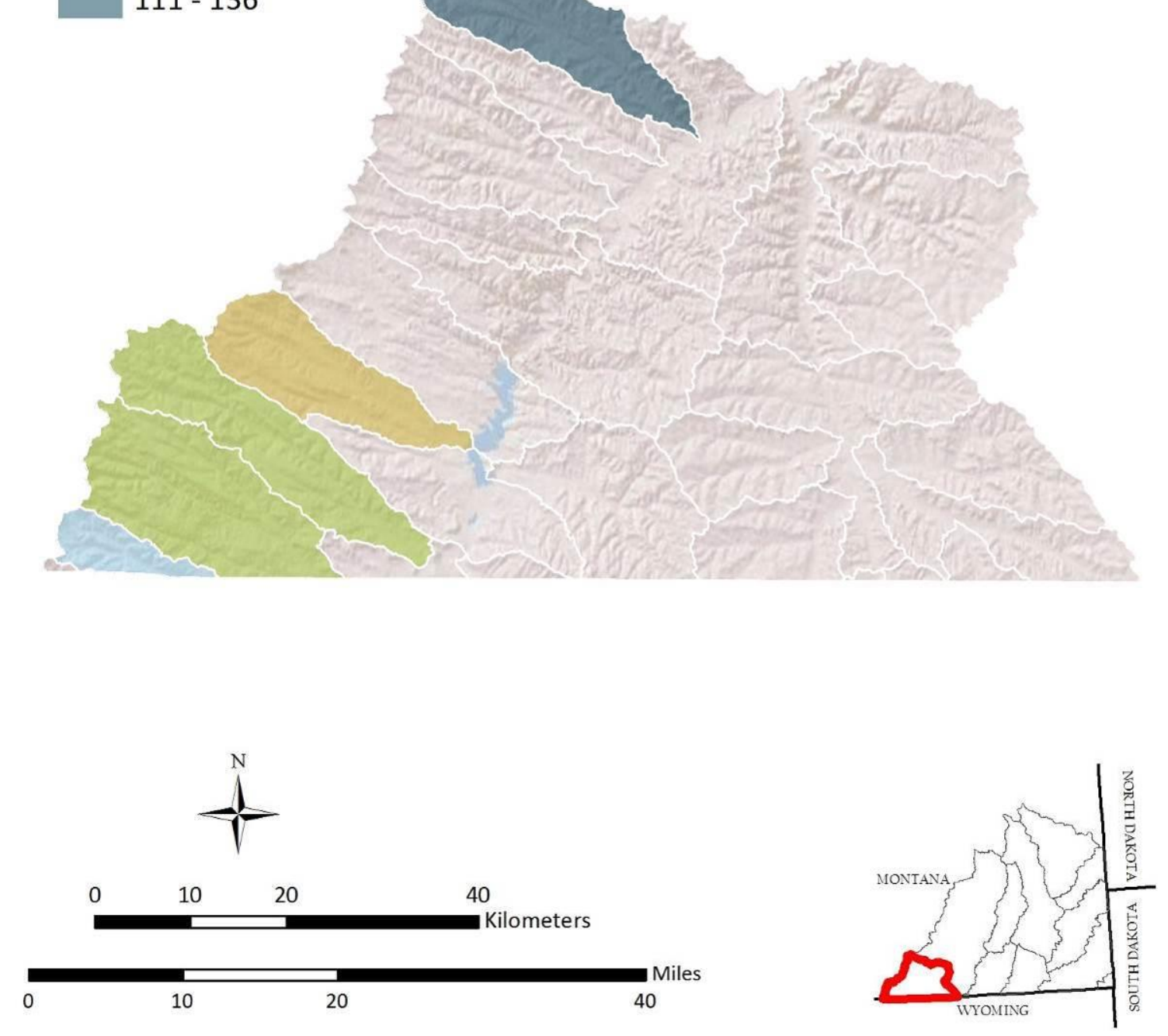

Figure 38. Acres of palustrine wetlands on Tribal lands by sixth code hydrologic unit in the Upper Tongue River watershed 